\title{
Geocronologia U-Pb, classificação e aspectos evolutivos do Granito Marajoara, Província Carajás
}

\author{
$U$-Pb geochronology, classification and evolutionary \\ aspects of Granite Marajoara, Carajás Province
}

\author{
Rodrigo Fabiano Silva Santos ${ }^{1,2}$ (D), Davis Carvalho de Oliveira ${ }^{1,2}$ (D), Fernando Fernandes da Silva ${ }^{1,2}$ (D) \\ 1 Universidade Federal do Pará - UFPA, Instituto de Geociências (IG), Grupo de Pesquisa Petrologia de Granitoides (GPPG) - \\ Caixa Postal 8608, CEP 66075-900, Belém, PA, BR (rfssantos@ufpa.br; davis@ufpa.br; ffernandes@ufpa.br) \\ Universidade Federal do Pará - UFPA, Instituto de Geociências (IG), \\ Programa de Pós-Graduação em Geologia e Geoquímica (PPGG). Belém, PA, BR
}

Recebido em 16 de abril de 2018; aceito em 5 de setembro de 2018

\begin{abstract}
Resumo
O Granito Marajoara (GrMj) é um stock intrusivo em granitoides mesoarqueanos do Domínio Rio Maria (DRM) da Província Carajás (PC). É formado por rochas leucocráticas: biotita monzogranito equigranular (BMzE) e heterogranular $(\mathrm{BMzH})$. Textura rapakivi e enclaves de granito porfirítico $(\mathrm{EGp})$ e microgranulares $(\mathrm{EMg})$ são restritos à fácies $\mathrm{BMzH}$. Os valores de susceptibilidade magnética (SM) e a presença de magnetita aproximam a fácies BMzH dos granitos da série magnetita, enquanto a variedade BMzE mostra afinidade com aqueles da série ilmenita por apresentar baixos valores de SM e opacos. São granitos peraluminosos similares aos ferroan. Mostram, ainda, afinidades com os granitos tipo-A oxidados (BMzH e EGp) e reduzidos (BMzE), como aquelas dos plútons das suítes Jamon e Velho Guilherme, respectivamente. Os EMg mostram afinidade com os granitos magnesianos e da série calcioalcalina, e os EGp são originados a partir da interação entre os líquidos EMg e BMzH. Os gaps composicionais entre as diversas variedades sugerem que seus magmas não são cogenéticos. Os EMg são representantes de um magmatismo básico oriundo do manto litosférico enriquecido e que teriam sido injetados na câmara magmática por underplating. As análises U-Pb em zircão (SHRIMP) fornecem idade de cristalização (1885 $\pm 6 \mathrm{Ma}$ ). O GrMj foi colocado em epizona em um ambiente de tectônica extensional. A zonalidade concêntrica do GrMj e a influência reduzida dos esforços regionais indicam que o transporte do magma se deu por diques. Dessa forma, a edificação do GrMj é resultante de ascensão vertical de magmas por meio de fraturas e acomodação ao longo dos planos da foliação regional E-W, seguida de uma mudança do fluxo vertical por um espalhamento lateral do magma.
\end{abstract}

Palavras-chave: Marajoara; Granito tipo-A; Enclaves; Paleoproterozoico; Província Carajás.

\begin{abstract}
The Marajoara granite $(\mathrm{MjGr})$ is a stock intrusive in Mesoarchean granitoids of the Rio Maria domain, Carajás Province.It is formed by hololeucocratic rocks: equigranular $(\mathrm{BMzE})$ and heterogranular $(\mathrm{BMzH})$ monzogranite. Rapakivi texture and occurrences of porphyritic granite (EGp) and microgranular enclaves $(\mathrm{EMg})$ are restricted to $\mathrm{BMzH}$ facies. Magnetic susceptibility (MS) values and the presence of magnetite show that the $\mathrm{BMzH}$ facies is akin to magnetite-seriesgranites, whereas the BMzE variety shows affinity with the ilmeniteones (low values of MS and opaque minerals). They are peraluminous and similar to the ferroan granites. These granitoids show affinities with oxidized (BMzH and EGp) and reduced (BMzE) A-type granites, and are related to the Jamon and Velho Guilherme suites, respectively. EMg hasan affinity with the magnesian granites and the calc-alkaline series, and EGp is originated from the interaction between EMg and BMzH liquids. Compositional gaps among the several varieties that constitute $\mathrm{MjGr}$ suggest that their magmas are not cogenetic. EMg represents basic magmatism from the enriched lithospheric mantle that would have been injected into the magma chamber during the underplating. The U-Pb zircon analyzes (SHRIMP) yield a crystallization age of $1885 \pm 6 \mathrm{Ma}$. MjGr was emplaced inepizone in an extensional tectonic environment. The concentric zoning in MjGr and the reduced or no influence of the regional efforts suggest transport of the magma through dikes. Thus, MjGr's construction results from the vertical rise of magmas through fractures and accommodation along the planes of the regional E-W foliation, followed by a change of vertical flow through a lateral scattering of the magma.
\end{abstract}

Keywords: Marajoara; A-type; Enclave; Paleoproterozoic; Carajás Province. 


\section{INTRODUÇÃO}

Desde a introdução dos termos granitos tipo-I e -S por Chappell e White (1974), rochas graníticas comumente foram classificadas de acordo com a natureza do seu protólito, sendo a fusão da crosta o principal mecanismo para a geração de granitos (Arndt, 2013; Chappell e White, 2001; Chappell et al., 2012; Pitcher, 1982, 1993). Nesse sentido, Loiselle e Wones (1979) criaram o termo "tipo-A", que se destinava a classificar granitos com teores elevados de $\mathrm{Na}_{2} \mathrm{O}+\mathrm{K}_{2} \mathrm{O}$, $\operatorname{HFSE}\left(\mathrm{Zr}\right.$, Nb e ETR), alta razão $\mathrm{FeO}_{\mathrm{t}} /\left(\mathrm{FeO}_{\mathrm{t}}+\mathrm{Mg}\right)$ e baixas concentrações $\mathrm{Ba}, \mathrm{Sr}$ e Eu, baixa fugacidade de oxigênio e reduzido conteúdo de $\mathrm{H}_{2} \mathrm{O}$. Esse tipo de granito, relacionado a ambientes anorogênicos, apresenta composições químicas distintas daquelas dos tipos I e S. Whalen et al. (1987) adicionaram como características típicas de granitos do tipo-A altos conteúdos de $\mathrm{SiO}_{2}, \mathrm{Ga}, \mathrm{Y}, \mathrm{Ce}$ e $\mathrm{Zn}$, alta razão de $\mathrm{Ga} / \mathrm{Al}$ e baixos conteúdos de $\mathrm{Al}_{2} \mathrm{O}_{3}$ e $\mathrm{CaO}$. Assim, foi criada a "classificação alfabética" (Frost et al., 2001), que se refere mais adequadamente à composição química e sua contribuição para a compreensão da evolução petrogenética de granitoides do que a sua relação com mecanismos petrológicos específicos envolvidos na gênese das rochas magmáticas, tais como a fusão parcial. No entanto, a distinção entre os diferentes tipos nem sempre foi tão simples. Isso é particularmente verdadeiro no caso dos granitos tipo-A e tipo-I altamente fracionados $\left(\mathrm{SiO}_{2}>72 \%\right.$ ) (King et al., 1997, 2001; Wu et al., 2003a), para os quais a definição levará em conta o contexto geológico sob estudo.

Rochas graníticas, em geral, representam líquidos com $\mathrm{SiO}_{2}>70 \%$, que marcam os estágios finais de evolução de um evento magmático. Diversos autores, em diferentes estudos (por exemplo, Barbarin, 1999; Chappell e White, 2001; Frost e Frost, 2013; Frost et al., 2001; Patiño Douce, 1999; Nardi e Bitencourt, 2009), têm sugerido classificações distintas para tais rochas, objetivando a melhor compreensão tanto dos processos envolvidos na origem e na segregação de líquidos, como daqueles que ocorrem durante a ascensão, o transporte e o alojamento, até a colocação final do magma na crosta (Oliveira et al., 2008, 2010). Nesse sentido, Dall'Agnol e Oliveira (2007), com base em parâmetros químico-mineralógicos e nas condições de fugacidade do oxigênio durante a cristalização, agruparam os granitos paleoproterozoicos da Província Carajás (PC) em três suítes distintas:

1. Suíte Jamon (oxidada - série magnetita);

2. Suíte Serra dos Carajás (moderadamente oxidada);

3. Suíte Velho Guilherme (reduzida - série ilmenita).

Os granitos tipo-A oxidados têm obtido crescente destaque na literatura, tendo grande relevância no Proterozoico Médio dos Estados Unidos (Anderson e Morrison, 2005), assim como no Cráton Amazônico, particularmente no
Domínio Rio Maria (DRM) (Dall'Agnol e Oliveira, 2007; Dall'Agnol et al., 2005; Oliveira et al., 2010).

O Granito Marajoara (GrMj), que ocorre na área da Vila Marajoara, sudeste do estado do Pará, porção sul da PC, é intrusivo em granitoides mesoarqueanos do tipo TGG e leucogranitos diversos, com idades que variam entre 2,96 e 2,87 Ga e que formam o embasamento do DRM (Almeida et al., 2011, 2013). Além do GrMj, o magmatismo granítico anorogênico desse terreno é marcado ainda pelas ocorrências dos granitos Musa, Jamon, Redenção e Bannach (Almeida et al., 2007; Dall'Agnol et al., 1999a; Oliveira et al., 2010), os quais foram agrupados na Suíte Jamon por Dall'Agnol et al. (1999c). O granito Manda Saia que ocorre nesse domínio ainda apresenta incertezas quanto a sua afinidade petrológica (CPRM, 2000; Leite, 2001). Tais granitos anorogênicos, quando datados pelos métodos $\mathrm{U} / \mathrm{Pb}$ e $\mathrm{Pb} / \mathrm{Pb}$ em cristais de zircão, fornecem idades de cristalização e colocação próximas de 1,88 Ga (Barbosa et al., 1995; Dall'Agnol et al., 1999a; Machado et al., 1991).

O GrMj apresentava, até o presente estudo, ausência de mapeamento geológico detalhado e escassez de informações petrográficas e geoquímicas, bem como a inexistência de dados geocronológicos de isótopos de $\mathrm{Pb}$ em zircão que determinasse sua idade de formação. Até então, somente o trabalho de Macambira (1992) tinha obtido uma idade de $1724 \pm 50$ Ma pelo método $\mathrm{Rb}$-Sr em rocha total e considerada de cristalização do plúton. Tal idade está em desacordo em aproximadamente $156 \mathrm{Ma}$ com aquelas obtidas para os demais granitos anorogênicos da PC. Diante disso, fez-se necessário a obtenção de dados geocronológicos pelo método $\mathrm{U}-\mathrm{Pb}$, o que pode aproximar a idade de cristalização do $\mathrm{GrMj}$ daquela dos demais plútons tipo-A do Paleoproterozoico da referida província. Tal informação, aliada à definição das fácies petrográficas que constituem esse maciço e de seus aspectos mineralógicos e geoquímicos, permitirá que se faça uma discussão sobre a gênese e a construção desse maciço, bem como dos processos envolvidos na evolução de seu magma gerador, além de avaliar se o enquadramento desse corpo granítico na Suíte Jamon é justificado.

\section{CONTEXTO GEOLÓGICO}

A PC está localizada na parte sudeste do Cráton Amazônico, que é composto de terrenos arqueanos e proterozoicos. Tassinari e Macambira (2004) e Santos (2003) propõem a divisão do Cráton Amazônico em províncias geocronológicas em torno de um núcleo arqueano, alongado NW-SE. Os terrenos circundantes foram formados por retrabalhamento e acreção crustal em cinturões móveis. Souza et al. (1996) subdividiram a $\mathrm{PC}$ em dois blocos diferentes, Rio Maria e Carajás (Figura 1A), e esta proposta foi posteriormente ratificada por Dall'Agnol et al. (2006). 
Durante o Paleoproterozoico, tanto o DRM quanto o Domínio Carajás foram palco de um extenso magmatismo granítico anorogênico de assinatura tipo-A e com diferenças significativas em termos de geoquímica, susceptibilidade magnética (SM) e mineralizações associadas (Dall'Agnol e Oliveira, 2007; Oliveira et al., 2008, 2010). São granitos stricto sensu de intraplaca, não foliados, de alto nível crustal, os quais são colocados em uma crosta rígida cortada por diques e que estão em contato discordante com suas encaixantes. Com idade em torno de 1,88 Ga (Tabela 1), intrudem ambos os blocos arqueanos (Dall'Agnol et al., 2005). A distribuição de suas fácies indica, em geral, um zoneamento concêntrico, com as fácies mais evoluídas ocupando a porção central dos maciços. Esses granitos foram atribuídos a três suítes - Jamon, Serra dos Carajás e Velho Guilherme -, de acordo com suas características petrográficas e geoquímicas, assim como o estado de oxidação de seus magmas (Dall'Agnol et al., 2005).

Os granitos tipo-A oxidados intrusivos nas rochas arqueanas do DRM foram agrupados na Suíte Jamon, representada pelos granitos Jamon, Musa, Marajoara, Manda Saia, Redenção e Bannach, os quais são da série magnetita de Ishihara (1977), que possuem alta razão $\mathrm{Fe} /(\mathrm{Fe}+\mathrm{Mg}$ ), alto valor de SM e, localmente, mineralizações de wolframita associada. Os granitos tipo-A moderadamente reduzidos que intrudem as unidades arqueanas dos domínios Carajás, Canaã dos Carajás e Sapucaia foram incluídos na Suíte Serra dos Carajás compreendida pelos plútons Seringa, Serra dos Carajás, Pojuca e Cigano, que possuem moderada SM, razão $\mathrm{Fe} /(\mathrm{Fe}+\mathrm{Mg})$ muito alta e, por vezes, com molibdenita e sulfeto de cobre disseminados. Na região do Xingu, os granitos tipo-A reduzidos da Suíte Velho Guilherme abrangem litotipos mineralizados em estanho, dominados por leucogranitos extremamente evoluídos, também com alta razão $\mathrm{Fe} /(\mathrm{Fe}+\mathrm{Mg})$ e, geralmente, mostrando baixos valores de SM. Essa suíte é constituída pelos maciços Velho Guilherme, Antônio Vicente, Mocambo, Ubim, Xingu, Benedita, Serra da Queimada e Bom Jardim, os quais cortam o complexo Xingu e rochas vulcânicas intermediárias a félsicas do Supergrupo Uatumã (Lamarão et al., 2012;

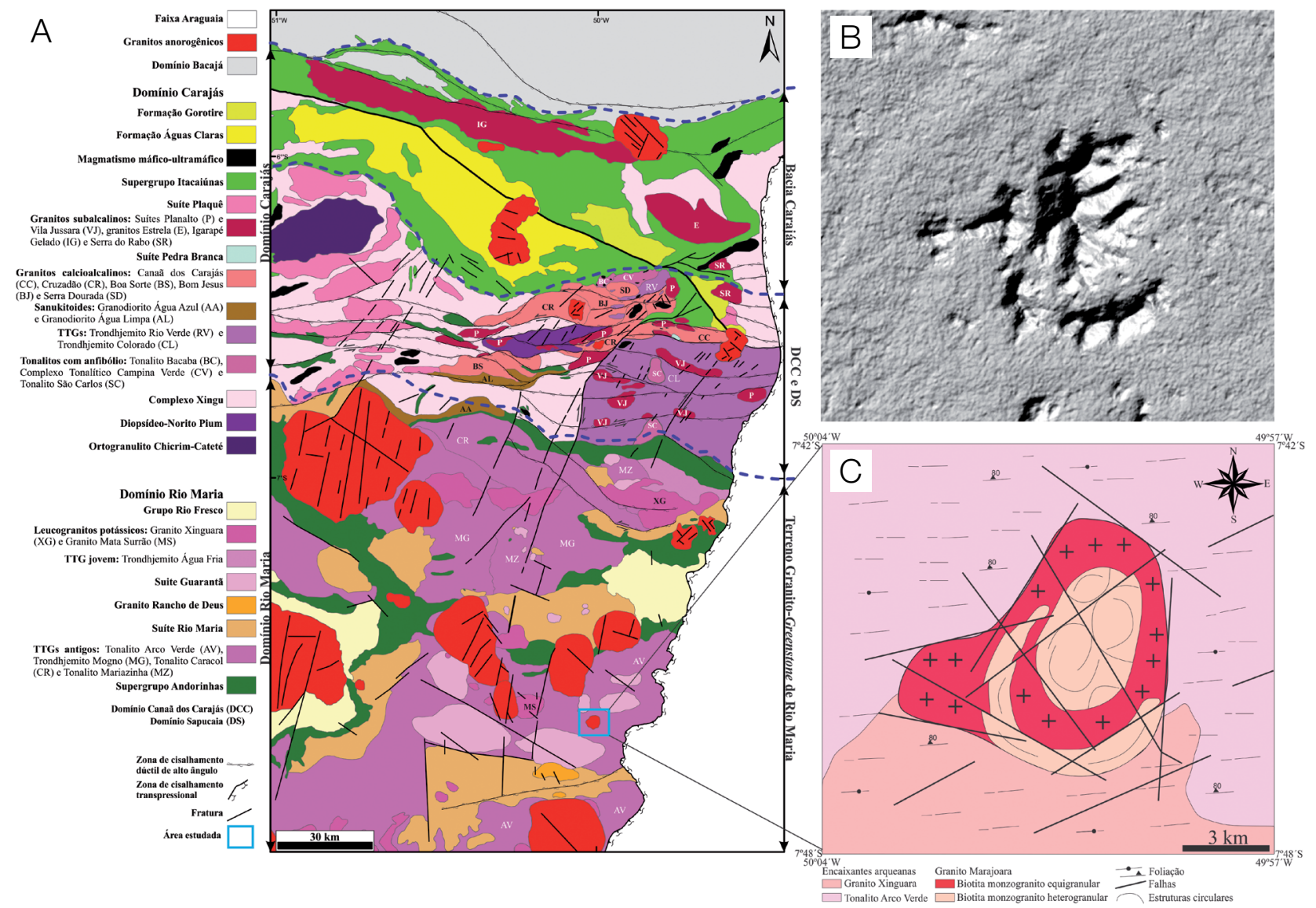

Fonte: modificado de Feio et al. (2013), Gabriel (2012), Guimarães et al. (2012), Oliveira et al. (2010) e Vasquez et al. (2008).

Figura 1. (A) Mapa das províncias geológicas do Cráton Amazônico; (B) imagem SRTM mostrando as diferenças topográficas e estruturais entre o Granito Marajoara e as rochas encaixantes; (C) mapa geológico e de fácies do Granito Marajoara. 
Teixeira, 1999). Diques máficos e félsicos, os quais podem estar relacionados ao evento gerador dos granitos paleoproterozoicos, intrudem as unidades arqueanas e os granitos paleoproterozoicos (Ferreira, 2009; Gastal, 1987; Huhn et al., 1988; Silva Júnior et al., 1999; Silva et al., 2016; Souza et al., 1990). Na Tabela 1, estão sintetizados os principais dados geocronológicos sobre os granitos que constituem tais suítes.

\section{GRANITO MARAJOARA}

\section{Geologia}

\section{Aspectos gerais}

O GrMj ocorre como um stock de forma subcircular e com aproximadamente $42 \mathrm{~km}^{2}$ de área aflorante $(7 \times 6 \mathrm{~km})$. É intrusivo em granitoides mesoarqueanos do DRM e foi inicialmente definido como anorogênico por Gastal (1988), e posteriormente incluído na Suíte Jamon por Dall'Agnol et al. (1999c). As regiões limítrofes do corpo são dominadas por um revelo plano, enquanto a porção central do maciço é constituída de morros e serras que podem atingir até $600 \mathrm{~m}$ de altitude, formando um conjunto de cristas orientados em duas direções principais (NE-SW e NW-SE), facilmente observados em imagem SRTM (Shuttle Radar Topography Mission) (Figura 1B). Ainda nessa porção, observam-se feições de relevo que sugerem fortemente a presença de fraturas anelares, as quais parecem delimitar as serras, marcando possíveis estruturas circulares coincidentes com os limites de fácies no interior do granito (Figura 1C). Corpos graníticos anelares limitados por falhas circulares semelhantes a ring-faults também foram descritos por outros autores nos maciços Redenção (Oliveira et al., 2005, 2010) e Bannach (Almeida et al., 2006).

Os lineamentos com padrões NE-SW e NW-SE afetam tanto as variedades graníticas do corpo quanto as suas rochas encaixantes, respeitando os trends da estruturação regional da PC. Essa província foi submetida a esforços extensionais que geraram falhamentos normais orientados segundo NE-SW e NW-SE, afetando supracrustais e granitos anorogênicos (Costa et al., 1995).

O GrMj é formado, essencialmente, por rochas de composição monzogranítica e hololeucocráticas. São subdivididas em duas variedades petrográficas: biotita-monzogranito equigranular (BMzE) e biotita monzogranito heterogranular (BMzH). A primeira, levemente mais enriquecida

Tabela 1. Síntese dos dados geocronológicos dos granitos anorogênicos e diques paleoproterozoicos da Província Carajás.

\begin{tabular}{lccc}
\hline Unidade & Método & Material analisado & Idade/referência \\
\hline Proterozoico & & & \\
$\begin{array}{l}\text { Carajás } \\
\text { Granito Cigano }\end{array}$ & $\mathrm{U}-\mathrm{Pb}$ & Zircão & $1883 \pm 2 \mathrm{Ma}^{1}$ \\
$\quad$ Granito Serra dos Carajás & $\mathrm{U}-\mathrm{Pb}$ & Zircão & $1880 \pm 2 \mathrm{Ma}^{1}$ \\
$\quad$ Granito Pojuca & $\mathrm{U}-\mathrm{Pb}$ & Zircão & $1874 \pm 2 \mathrm{Ma}^{1}$ \\
$\begin{array}{l}\text { Domínio Rio Maria } \\
\text { Granito Musa }\end{array}$ & $\mathrm{U}-\mathrm{Pb}$ & Zircão & $1883 \pm 52 \mathrm{Ma}^{1}$ \\
Granito Jamon & $\mathrm{Pb}-\mathrm{Pb}$ & Zircão & $1885 \pm 32 \mathrm{Ma}^{2}$ \\
Granito Redenção & $\mathrm{Pb}-\mathrm{Pb}$ & Zircão & $1870 \pm 68 \mathrm{Ma}^{2}$ \\
Granito Seringa & $\mathrm{Pb}-\mathrm{Pb}$ & Zircão & $1892 \pm 30 \mathrm{Ma}^{3}$ \\
Granito Marajoara & $\mathrm{Rb}-\mathrm{Sr}$ & Rocha total & $1724 \pm 50 \mathrm{Ma}^{4}$ \\
Granito São João & $\mathrm{Zircão}$ & $1895 \pm 50 \mathrm{Ma}^{5}$ \\
Região do Xingu & & & \\
Granito Velho Guilherme & $\mathrm{Pb}-\mathrm{Pb}$ & Zircão & $1823 \pm 13 \mathrm{Ma}^{6}$ \\
Granito Antônio Vicente & $\mathrm{Zircão}$ & $1867 \pm 4 \mathrm{Ma}^{7}$ \\
$\quad$ Granito Mocambo & Zircão & $1865 \pm 4 \mathrm{Ma}^{7}$ \\
Diques & $\mathrm{Pb}-\mathrm{Pb}$ & & \\
Dique félsico & & Zircão & $1885 \pm 2 \mathrm{Ma}^{8}$ \\
Dique félsico & $\mathrm{Pb}-\mathrm{Pb}$ & Rocha total & $1707 \pm 17 \mathrm{Ma}^{9}$ \\
Dique intermediário & $\mathrm{Rb}-\mathrm{Sr}$ & Rocha total & $1874 \pm 110 \mathrm{Ma}^{10}$ \\
Dique máfico & $\mathrm{Rb}-\mathrm{Sr}$ & Agregado máfico & $1802 \pm 22 \mathrm{Ma}^{11}$ \\
Diques riolíticos & $\mathrm{K}-\mathrm{Ar}$ & Zircão & $1887 \pm 2 \mathrm{Ma}^{12}$ \\
Diques riolíticos & $\mathrm{Pb}-\mathrm{Pb}$ & Zircão & $1880 \pm 3 \mathrm{Ma}^{13}$ \\
\hline
\end{tabular}

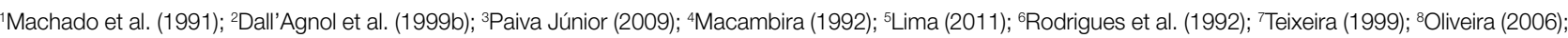
${ }^{9}$ Gastal (1987); ${ }^{10}$ Rivalenti et al. (1998); ${ }^{11}$ Silva Júnior et al. (1999); ${ }^{12}$ Ferreira (2009); ${ }^{13}$ Silva et al. (2016). 
em minerais máficos, exibe textura equigranular média, localmente fina, enquanto a fácies BMzH possui textura inequigranular média a grossa, onde destacam-se os cristais grossos de feldspatos. No mapa geológico de fácies (Figura 1C), observa-se que a variedade BMzE ocupa a periferia do plúton, onde o relevo é mais arrasado, enquanto a fácies $\mathrm{BMzH}$ forma o arcabouço das serras e morros da porção central do corpo (Figura 2A). A relação da fácies $\mathrm{BMzH}$ com as principais elevações é marcante nesse corpo, assim como observado no Maciço Redenção (Oliveira et al., 2005), servindo como critério para delimitação da fácies $\mathrm{BMzH}$ no mapa de fácies.

Enclaves de granito pórfirítico (EGp) são frequentes no $\mathrm{GrMj}$, onde apresentam forma subcircular e dimensões de até $3 \mathrm{~m}$ de comprimento (Figura 2B). Encontram-se sempre associados à fácies $\mathrm{BMzH}$ (Figura $2 \mathrm{C}$ ), em que mostram feições que indicam a ocorrência de processos de magma mingling, em que cristais grossos de feldspatos, e mais raramente de quartzo, pertencentes ao granito hospedeiro, são encontrados no interior dos enclaves (Figura 2D). Possuem textura porfirítica com fenocristais de quartzo, microclínio e plagioclásio, imersos em uma matriz de granulação mais fina e, ainda, exibem composição variando de granodiorítica a monzogranítica. Estes, quando desprovidos de fenocristais, apresentam aspecto microgranular (enclaves microgranulares - EMg), tornam-se claramente mais enriquecidos em minerais máficos e são mais angulosos (Figura 2E).

\section{Relação de contato com suas rochas encaixantes}

$\mathrm{O}$ GrMj é intrusivo em granitoides mesoarqueanos, onde trunca a foliação regional ENE-WSW desenvolvida no Tonalito Arco Verde (2,97 Ga) e nos leucogranitos da Suíte Guaratã $(2,87 \mathrm{Ga})$. Localmente na zona de contato ocorrem xenólitos das rochas encaixantes tanto no granito quanto nos enclaves pórfiros (Figuras 2D e 2F), os quais se apresentam fortemente deformados, de coloração cinza-escura e compostos essencialmente de plagioclásio, quartzo e minerais máficos. Os dados da análise modal realizada em uma amostra do xenólito (amostra GDR-9E; Tabela 2), quando plotados no diagrama Q-A-P (Streckeisen, 1976; Figura 3), permitem classificá-lo como tonalito, o que a distingue totalmente dos EGp encontrados ocasionalmente no interior do corpo. A forma angulosa desses xenólitos e o caráter isotrópico das rochas que formam o plúton granítico demonstram a existência de alto contraste de viscosidade entre a intrusão granítica e suas rochas encaixantes. Isso evidencia que a colocação do granito se deu quando o seu magma tinha uma importante fração líquida em contraponto à rocha encaixante que estava totalmente solidificada e mais fria. De modo geral, o contato entre o granito e sua encaixante se dá de forma brusca, sendo bem exposto no campo (Figura 2F).

\section{PETROGRAFIA}

As fácies que constituem o GrMj são bastante homogêneas composicionalmente, as quais possuem composição monzogranítica, com texturas variadas, apresentando termos equigranulares médios, heterogranulares médios a grossos e porfiríticos. Titanita, minerais opacos, allanita, apatita e zircão ocorrem como minerais acessórios primários e clorita, epidoto, sericita-muscovita, argilominerais e fluorita como as fases secundárias. EGp e EMg serão aqui tratados como líquidos independentes, haja vista suas ocorrências expressivas e importância na construção do plúton Marajoara.

\section{Composições modais e classificação}

Foram realizadas 33 análises modais, as quais foram plotadas posteriormente nos diagramas Q-A-Pe Q-A+P-M (Figura 3), e seguiram a classificação da International Union of Geological Sciences (IUGS) (Le Maitre et al., 2002; Streckeisen, 1976) na Tabela 2 estão listadas as mais representativas. A maioria das variedades é hololeucocrática $(\mathrm{M}<10 \%)$, à exceção dos $\mathrm{EMg}$, que apresentam aproximadamente $20 \%$ de $\mathrm{M}$.

As análises modais mostram que os conteúdos médios de quartzo $(\mathrm{Qz})$ e a média das razões plagioclásio/microclínio $(\mathrm{Pl} / \mathrm{Mc})$ não variam significativamente nas diferentes fácies, com valores de 33,4\% para $\mathrm{BMzH}, 32,8 \%$ para $\mathrm{BMzE}$ e 1,0 para ambas, respectivamente. No entanto, as maiores razões $\mathrm{Pl} / \mathrm{Mc}$ pertencem aos enclaves, as quais decrescem dos $\mathrm{EMg}$ $(4,4)$ para os EGp $(1,9)$, enquanto o conteúdo modal médio de Qz é significativamente inferior no primeiro $(25,9 \%) \mathrm{em}$ relação às demais variedades do $\mathrm{GrMj}$ (Tabela 2). Com tais variações, os dados das análises modais, quando plotados no diagrama Q-A-P (Streckeisen, 1976), demonstram que os EGp apresentam composição transicional entre o campo do granodiorito para aquele do monzogranito, enquanto os EMg são essencialmente granodiríticos (Figura 3), contrastando fortemente com a composição monzogranítica das duas fácies do GrMj e dos demais plútons da Suíte Jamon (Oliveira et al., 2009).

Os conteúdos modais médios de minerais máficos, de maneira geral, são equivalentes [BMzH $(4,1 \%)$ e $\mathrm{BMzE}$ $(4,9 \%)$ - ver diagrama Q-(A+P)-M (Figura 3). Conteúdos semelhantes também são observados para os EGp $(5,2 \%)$, que os aproximam das variedades anteriores pelo caráter hololeucocrático $(\mathrm{M}<10 \%)$. Por outro lado, os EMg apresentam conteúdo médio de minerais máficos de 20,5\% (Tabela 2), significantemente mais elevados do que aqueles das demais variedades. Nas variedades BMzH e EGp, a biotita tende a ceder lugar gradativamente à clorita, que atinge teores médios de $0,8 \%$ (Tabela 2 ) que, aliado à presença marcante de fluorita, indicam que o líquido que originou essas rochas era, comparativamente, enriquecido em constituintes voláteis. 

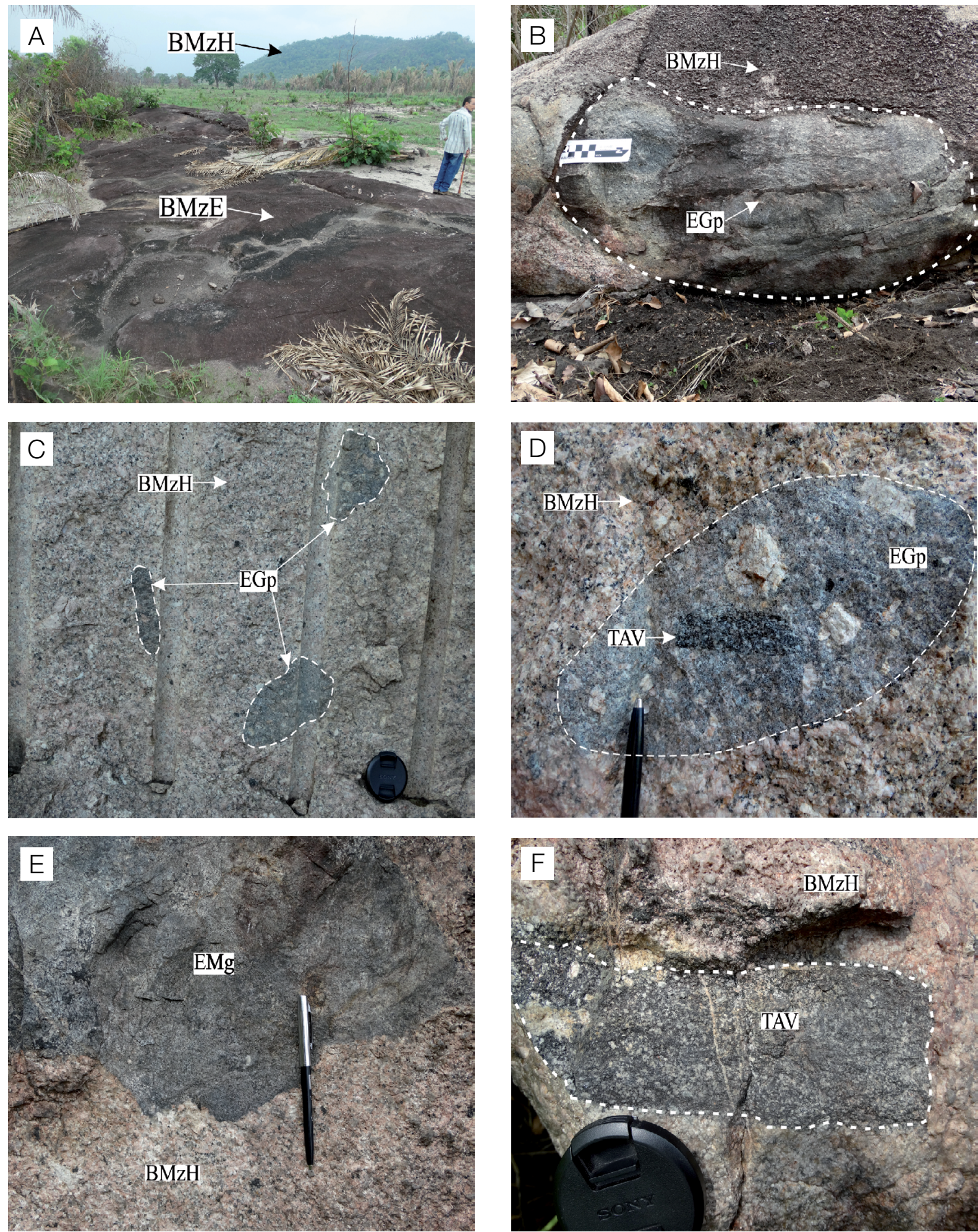

BMzH: biotita monzogranito heterogranular; BMzE: biotita monzogranito equigranular; EMg: enclaves microgranulares; EGp: enclaves de granito porfirítico; TAV: Tonalito Arco Verde.

Figura 2. Principais feições mesoscópicas do Granito Marajoara: (A) forma de relevo e modo de ocorrência das variedades graníticas; $(B)$ e $(C)$ modo de ocorrência dos enclaves de granito porfirítico e suas relações com a fácies biotita monzogranito heterogranular; (D) feições de mingling mais comuns nos enclaves de granito porfirítico; (E) aspecto textural do enclave microgranular; (F) encaixante Tonalito Arco Verde associada ao biotita monzogranito heterogranular. 
Tabela 2. Análises modais das amostras do Granito Marajoara.

\begin{tabular}{|c|c|c|c|c|c|c|c|c|c|c|c|c|c|c|}
\hline Fácies & & & $\mathrm{zH}$ & & & BMzE & & & EC & ip & & EN & $\lg$ & TAV \\
\hline & GDR & RDF & RDF & RDF & GDR & RDF & $\mathrm{RDF}$ & GDR & GDR & RDF & RDF & RDF & RDF & GDR \\
\hline Amostra/IVIIneral (\%) & 9F-B & 8 & $9 A$ & $14 \mathrm{~A} / \mathrm{B}$ & $8 \mathrm{~B}^{1}$ & 2 & 11 & 9DB & 9F-A & 9B3 & 14B & 9B1 & 9B2 & $9 \mathrm{E}$ \\
\hline Quartzo & 46,0 & 38,1 & 30,8 & 34,0 & 30,2 & 33,6 & 32,9 & 35,7 & 43,3 & 29,5 & 39,7 & 26,8 & 25 & 30,1 \\
\hline Alcali-feldspato & 25,2 & 32,3 & 31,5 & 29,7 & 38,5 & 28,3 & 27,6 & 21,7 & 16,1 & 19,9 & 16,3 & 10,9 & 10,1 & 4 \\
\hline Plagioclásio & 26,6 & 22,9 & 31,7 & 28,7 & 26,5 & 31,6 & 31,4 & 34,2 & 33,2 & 41,4 & 35,8 & 46,4 & 47,3 & 48,9 \\
\hline Biotita & 1,3 & 1,6 & 2,9 & 3,1 & 3,1 & 3,9 & 5,4 & 5,5 & 5,4 & 5,2 & 5,8 & 18 & 19,5 & 14 \\
\hline Opacos $^{2}$ & 0,1 & 0,9 & 1,0 & 0,7 & $\mathrm{Tr}$ & 0,3 & - & 1 & 0,5 & 0,7 & 0,7 & 1,5 & 1,3 & 1,4 \\
\hline Titanita & $\operatorname{Tr}$ & 0,6 & 0,3 & 0,3 & 0,2 & 0,3 & 0,2 & - & - & - & - & 0,1 & 0,1 & - \\
\hline Allanita & - & 0,2 & 0,2 & 0,5 & 0,2 & 0,3 & 0,1 & - & - & 0,2 & 0,2 & - & 0,1 & - \\
\hline Clorita & 0,2 & 1,9 & 0,4 & 1,1 & - & 0,1 & - & 0,6 & 0,7 & 2,0 & 0,3 & 0,4 & 0,2 & - \\
\hline Muscovita & - & 0,8 & 0,4 & 0,8 & 0,8 & 1,1 & 1,8 & 0,6 & $\operatorname{Tr}$ & 0,6 & 0,4 & 0,1 & - & 0,5 \\
\hline Fluorita & 0,1 & 0,1 & 0,2 & 0,4 & 0,1 & 0,2 & 0,2 & - & - & 0,2 & 0,3 & 0,2 & 0,1 & 0,2 \\
\hline Epídoto & 0,1 & 0,5 & 0,2 & 0,3 & - & 0,1 & 0,1 & 0,3 & 0,2 & 0,3 & 0,3 & 0,2 & 0,1 & - \\
\hline Acessórios (Ap+Zr) & $\operatorname{Tr}$ & 0,1 & 0,2 & 0,3 & $\operatorname{Tr}$ & 0,3 & 0,2 & 0,1 & 0,2 & 0,2 & 0,1 & 0,3 & 0,2 & 0,9 \\
\hline $\mathrm{A}+\mathrm{P}$ & 51,8 & 55,2 & 63,2 & 58,4 & 65 & 59,9 & 59,1 & 55,9 & 49,3 & 61,3 & 52,1 & 57,3 & 57,4 & 52,9 \\
\hline Máficos & 1,7 & 3,3 & 4,3 & 4,7 & 3,5 & 4,8 & 5,7 & 7,4 & 6,8 & 6,1 & 6,7 & 19,8 & 21,1 & 17 \\
\hline $\mathrm{Pl} / \mathrm{Mc}$ & 1,1 & 0,7 & 1,0 & 1,0 & 0,7 & 1,1 & 1,1 & 1,6 & 2,1 & 2,8 & 2,2 & 4,1 & 4,7 & 12,0 \\
\hline Quartzo* & 47,0 & 40,8 & 32,7 & 36,8 & 31,5 & 36,0 & 35,8 & 38,7 & 46,8 & 35,4 & 43,3 & 32,68 & 30,34 & 36,2 \\
\hline Alcali-feldspato* & 25,8 & 34,6 & 33,5 & 32,2 & 40,1 & 30,2 & 30,0 & 23,5 & 17,4 & 17,0 & 17,8 & 13,29 & 12,26 & 4,9 \\
\hline Plagioclásio* & 27,2 & 24,5 & 33,8 & 31,1 & 27,6 & 33,8 & 34,2 & 37,1 & 35,9 & 47,6 & 39,0 & 54,03 & 57,4 & 58,9 \\
\hline Número de pontos & 1800 & 1800 & 1800 & 1800 & 1500 & 1800 & 1800 & 1800 & 1800 & 1800 & 1800 & 1800 & 1800 & 1500 \\
\hline
\end{tabular}

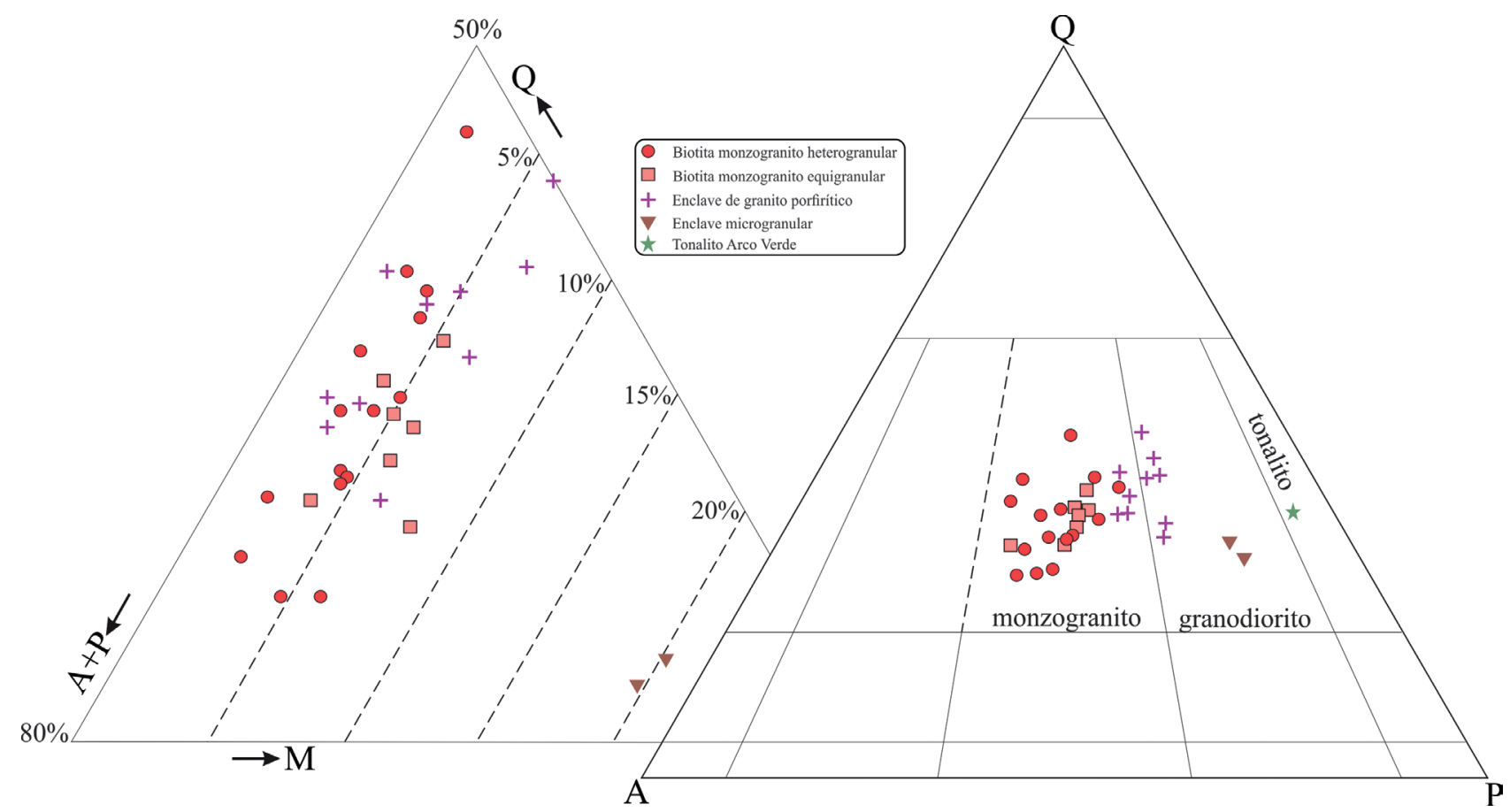

Fonte: modificado de Le Maitre et al. (2002) e Streckeisen (1976).

Figura 3. Diagramas Q-A + P-M e Q-A-P, mostrando a distribuição modal no Granito Marajoara. 


\section{Aspectos texturais}

\section{Fácies $B M z E$}

Exibe caráter isotrópico, coloração cinza esbranquiçada e textura equigranular média (Figura 4A). A fração média, mais abundante e formada pelos minerais essenciais, tem dimensões variáveis entre 2 e $4 \mathrm{~mm}$ e a fina, de ocorrência mais restrita, e é representada por cristais de quartzo e, subordinadamente, por minerais máficos (biotita). Ao microscópio, esta fácies apresenta textura granular hipidiomórfica com cristais sub-e automorfos de feldspatos e quartzo (Figura 4B). Os agregados de minerais máficos são pouco expressivos e dominados pela biotita, com quantidades subordinadas de titanita, zircão e allanita e presença restrita de fluorita. O quartzo é o mineral mais desenvolvido desta fácies (até $3,5 \mathrm{~mm}-\mathrm{Qz}_{1}$; Figura 4B) e exibe contatos irregulares com os cristais de feldspatos. É comum a ocorrência de cristais anédricos de dimensões inferiores $\left(\sim 1 \mathrm{~mm}-\mathrm{Qz}_{2}\right)$ como inclusões nos cristais maiores de feldspatos $\left(\mathrm{Mc}_{1}\right.$ e $\left.\mathrm{Pl}_{1}\right)$, marcando, sobretudo, as fases de crescimento deles. O quartzo também ocorre sob a forma de cristais irregulares associados aos agregados máficos e inclusos na biotita. Este último tipo é muito restrito no GrMj, provavelmente por causa do seu caráter relativamente evoluído e baixo conteúdo de fases ferromagnesianas, uma vez que esse tipo é mais comum em fácies menos evoluídas de outros corpos da Suíte Jamon, sendo interpretado como produto da transformação (excesso de sílica) do anfibólio para biotita (Dall'Agnol, 1982; Gastal, 1987; Oliveira et al., 2005).

Os feldspatos mostram seções prismáticas (1-3 mm; Figura 4B), sendo que nos cristais de microclínio as pertitas são pouco frequentes e do tipo string (Smith, 1974). Nos cristais menores, as inclusões são mais raras do que no $\mathrm{Mc}_{1}$ e os intercrescimentos granofíricos com o quartzo, quando ocorrem, envolvem praticamente todo o cristal. O Plagioclásio varia de oligoclásio sódico a albita $\left(\mathrm{An}_{11-9}\right)$ podendo chegar à albita $\left(\mathrm{An}_{6-3}\right.$ até $\left.\mathrm{An}_{0}\right)$ nas bordas. Localmente, apresenta núcleos mais cálcicos (oligoclásio sódico, $\mathrm{An}_{16-14}$ ). $\mathrm{O}$ zoneamento normal é menos evidente que nos cristais de maiores dimensões que ocorrem nas demais fácies, sendo nítidas as bordas albíticas, normalmente finas e regulares. Há, localmente, cristais de plagioclásio inclusos no microclínio, sugerindo gerações distintas deste mineral. Tais aspectos são similares àqueles obtidos para o plagioclásio da fácies leucomonzgranítica dos granitos Bannach e Redenção (Almeida et al., 2006; Oliveira et al., 2005).

A biotita amarronzada ocorre em agregados de lamelas $(0,3$ a $1,5 \mathrm{~mm})$, com contornos irregulares e intercrescidos com quartzo, geralmente formando agregados máficos (Figura 4C). Suas bordas ocasionalmente apresentam-se corroídas e alteradas para muscovita, principalmente quando em contato com o quartzo, indicando uma reação da biotita formada precocemente com o líquido remanescente (Figura 4D). Alguns cristais apresentam inclusões de minerais opacos, apatita, allanita e zircão, onde este desenvolve halos pleocroicos (Figura 4E).

Os minerais acessórios podem ser identificados como:

1. titanita: bastante expressiva nesta fácies $(>0,2 \%$; Tabela 2), mostra coloração amarronzada e ocorre como finos cristais $(0,1 \mathrm{~mm})$ sub- e automorfos e, por vezes, desenvolve seções poligonais típicas;

2. allanita: possui ocorrência restrita com tamanho médio de 0,2 mm. Os cristais desse mineral apresentam-se de forma automorfa, metamictizados, com desenvolvimento de coroas de epidoto e zonados (Figura 4F);

3. zircão e apatita: ocorrem como finos cristais automorfos $(<0,1 \mathrm{~mm})$ que, por vezes, apresentam-se bastante corroídos, inclusos na biotita (Figura 4E) e, localmente, na allanita, ou, ainda, associados aos minerais opacos, ou até mesmo inclusos nestes (apatita);

4. opacos (ilmenita \pm magnetita): apresentam-se como cristais subautomorfos e mais raramente com seções quadráticas ou hexagonais, com tamanho médio $<0,1 \mathrm{~mm}$. Ocorrem frequentemente inclusos na biotita, no microclínio e no plagioclásio. Outra forma de ocorrência de alguns opacos é ao longo das clivagens das biotitas, como cristais secundários, submilimétricos e de forma alongada, sugerindo que esses minerais se formaram a partir da alteração da mica.

Os minerais secundários são:

1. fluorita: forma pequenos cristais xenomórficos, geralmente associados a agregados máficos;

2. muscovita: ocorre sob a forma de finas palhetas geralmente associadas à biotita, sendo considerada como produto de alteração da mica primária;

3. epidoto: apresenta-se principalmente envolvendo cristais de allanita, sendo interpretado como produto de alteração deste mineral e, por vezes, como produto de alteração do plagioclásio mais cálcico;

4. sericita: também resulta da transformação (saussuritização) do plagioclásio e dos argilominerais como produto de alteração do feldspato alcalino.

\section{Fácies $B M z H$}

A fácies $\mathrm{BMzH}$ distingue-se do BMzE por possuir caráter heterogranular e granulação comparativamente mais grossa, resultando em aspectos texturais bastante contrastantes entre as duas variedades (Figura 5A). Em amostras de mão, o BMzH apresenta uma coloração rosada com porções esbranquiçadas e, assim como na fácies anterior, possui aspecto isotrópico. A fração predominante exibe granulação média, dimensões variáveis entre 2,0 e 5,0 $\mathrm{mm}$ e é composta pelos minerais essenciais e biotita, assemelhando-se texturalmente aos 
cristais descritos na fácies BMzE. A outra fração possui granulação grossa (dimensões entre 7 e $15 \mathrm{~mm}$ ) e é constituída de feldspatos (Figura 5B), que raramente atinge dimensões de até $35 \mathrm{~mm}$. Localmente, observa-se a ocorrência de finos cristais de molibdenita disseminados (Figura 5A) e feições do tipo rapakivi (Figura 5C) e "anti-rapakivi”. O microclínio
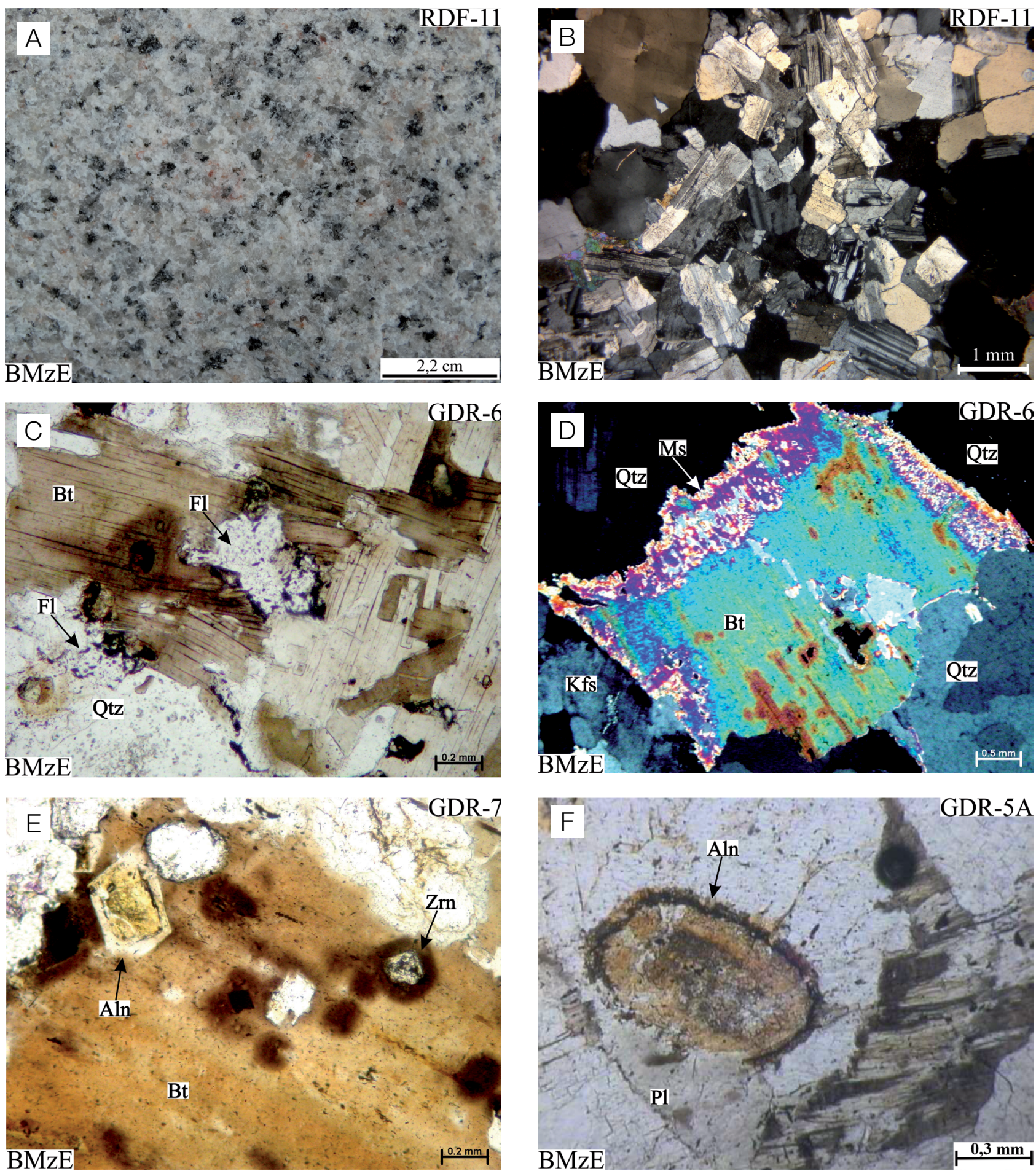

BMzE: biotita monzogranito equigranular; Bt: biotita; Fl: fluorita; Qtz: quartzo; Ms: muscovita; Kfs: k-feldspato; Zrn: zircão; Aln: allanita; PI: plagioclásio.

Figura 4. Principais feições meso e microscópicas do BMzE: (A) textura fanerítica; $(B)$ textura equigranular média; (C) lamelas de biotita interpenetradas com quartzo; (D) borda de biotita corroída e alterada para muscovita; (E) biotita com inclusão de minerais acessórios; (F) allanita metamictizada zonada. Abreviações dos minerais conforme Siivola e Schmid (2007). 

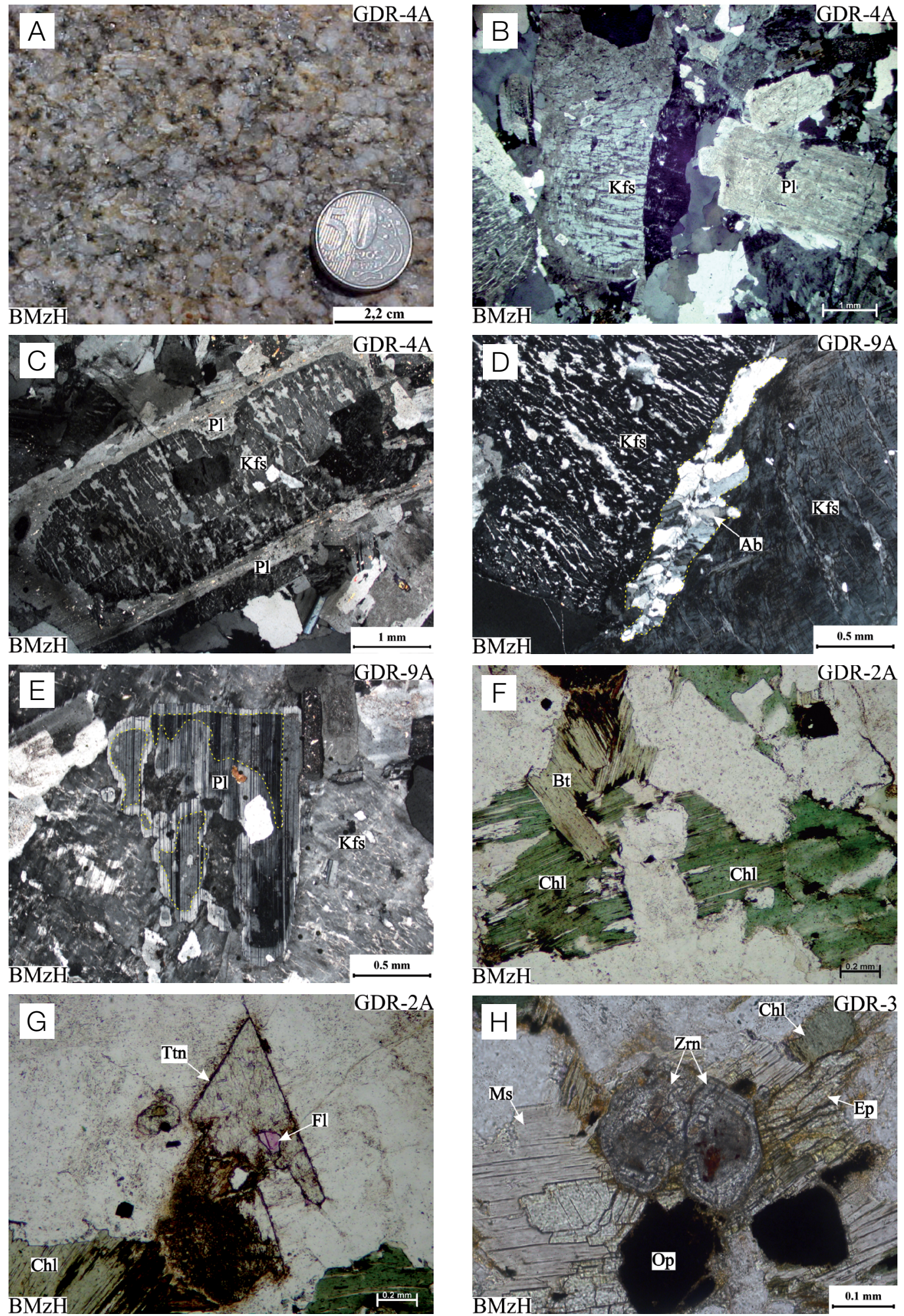

BMzH: biotita monzogranito heterogranular; Kfs: k-feldspato; Pl: plagioclásio; Ab: albita; Bt: biotita; Chl: clorita; Ttn: titanita; Fl: fluorita; Ms: muscovita; Zrn: zircão; Ep: epidoto; Op: opaco.

Figura 5. Feições meso e microscópicas da fácies BMzH: (A) textura fanerítica grossa com molibdenita disseminada; (B) textura hipidiomórfica heterogranular; (C) textura rapakivi; (D) albita intergranular do tipo coroa trocada; (E) patchy zonning; $(F)$ biotita transformada para clorita; $(\mathrm{G})$ e $(\mathrm{H})$ principais minerais acessórios (titanita + zircão + minerais opacos + fluorita). Abreviações dos minerais conforme Siivola e Schmid (2007). 
varia de pertítica (veios e filmes) a mesopertítica (manchas disformes macladas - patches) e, por vezes, nos contatos $\mathrm{Mc} / \mathrm{Mc}$ há desenvolvimento de albita intergranular ou em coroas trocadas (Smith, 1974). Esta se apresenta na forma de agregados de pequenos grãos maclados de albita (Figura 5D). Os contatos $\mathrm{Mc} / \mathrm{Pl}$ são marcados pela formação de auréolas albíticas, acompanhadas ou não de mirmequitas (Figura 5E). Englobam inclusões de biotita, plagioclásio e, mais raramente, titanita, zircão e opacos. Nesta fácies são marcantes também as transformações das fases feldspáticas, com a formação de albita em tabuleiro xadrez sobre o microclínio primária (albita chess board; Smith, 1974) (Figura 5E).

Nessas fácies não há evidências de corrosão do quartzo e os intercrescimentos granofíricos entre microclínio e quartzo não são frequentes. O plagioclásio se assemelha composicionalmente e em certos aspectos texturais, como descrito na fácies $\mathrm{BMzE}$, embora, nesta fácies, seus cristais alcancem maiores dimensões (em torno de $7 \mathrm{~mm}$ ). Sua composição varia, em geral, de oligoclásio sódico a albita $\left(\mathrm{An}_{14-9}\right)$, podendo chegar a oligoclásio sódico $\left(\mathrm{An}_{18-16}\right)$ nas porções mais centrais até albita $\left(\mathrm{An}_{8}\right.$ até $\mathrm{An}_{0}$ ), nas bordas. Os núcleos mais cálcicos ocupam boa parte dos cristais e mostram contornos irregulares (Figura 5B), enquanto as zonas de oligoclásio sódico-albita são mais estreitas, regulares e costumam apresentar caráter intersticial. São comuns seções mostrando patchy zoning (Vance, 1965), com bordas sódicas irregulares invadindo o núcleo mais cálcico do cristal (Figura 5E). O plagioclásio também é frequente como inclusões no microclínio, onde aparece em cristais de menores dimensões $(1,0$ a 2,0 mm). Esse tipo apresenta-se, também, bastante transformado (descalcificado), especialmente quando ocorre próximo aos agregados de minerais máficos, havendo o desenvolvimento no seu interior de sericita (muscovita), epidoto, argilo-minerais e, por vezes, fluorita.

O quartzo $\left(\mathrm{Qz}_{1}\right)$ forma cristais com dimensões análogas, porém geralmente um pouco inferiores às dos feldspatos. Seus cristais são sub- a automorfos, muitas vezes fornecendo seções grosseiramente rômbicas ou hexagonais. Seus contatos com os feldspatos são geralmente retilíneos e interpenetrados com os minerais máficos. Localmente, possui pequenas inclusões de feldspatos, biotita, muscovita e acessórios. O Qz ${ }_{1}$ constitui a quase totalidade do quartzo presente nessa fácies, enquanto o $\mathrm{Qz}_{2}$, embora subordinado, é mais abundante que na fácies equigranular, ocorrendo essencialmente como inclusões nas bordas do feldspato alcalino e, mais raramente, no plagioclásio sódico. $\mathrm{O} \mathrm{Qz}$ torna-se mais expressivo, sobretudo, nos EGp.

A biotita ocorre em quantidades pouco expressivas e, bem como os minerais acessórios primários e secundários, conservam em linhas gerais as feições descritas nas fácies BMzE, no entanto ela se mostra intensamente transformada em clorita (Figura 5F), sendo comum o desenvolvimento de fluorita associada aos agregados de biotita/clorita e acessório primários (Figuras $5 \mathrm{G} \mathrm{e} 5 \mathrm{H}$ ).

\section{Enclaves}

Os tipos texturais de enclaves graníticos que ocorrem no $\mathrm{GrMj}$, e que são considerados como uma das variedades envolvidas na construção do plúton, ocorrem sempre associados à fácies $\mathrm{BMzH}$ (Figuras 2B a 2E). Diferem das fácies anteriormente descritas por possuírem um caráter francamente porfirítico (EGp) ou, mais restritamente, equigranular fino quando desprovidos de fenocristais (EMg) (Figura 2E). O EGp apresenta coloração cinza-escura e típica textura porfirítica com fenocristais de microclínio, plagioclásio e, subordinadamente, de quartzo, imersos em uma matriz de granulação fina a muito fina $(<0,1 \mathrm{~mm})$, constituída pelos minerais essenciais e biotita (Figuras 6A e 6B). A matriz representa cerca de $70 \%$ da rocha, e assemelha-se, em termos composicionais e texturais, aos $\mathrm{EMg}$, divergindo apenas no conteúdo de biotita (Tabela 2 e Figura 6C). Em termos dos minerais essenciais, isso implica na formação de um segundo tipo textural de plagioclásio $\left(\mathrm{Pl}_{2}\right)$, bem como na maior abundância de $\mathrm{Mc}_{2}$ e $\mathrm{Qz}_{2}$ (Figuras 6B e 6C). Tais enclaves são semelhantes àqueles encontrados em alguns corpos da Suíte Jamon, como é o caso dos maciços Musa (Gastal, 1987), Redenção (Oliveira et al., 2005) e Bannach (Almeida et al., 2006), no entanto são de ocorrência extremamente restrita quando comparados àqueles do $\mathrm{GrMj}$.

Os fenocristais de feldspatos apresentam seções prismáticas com dimensões, em geral, entre 4 e $8 \mathrm{~mm}$ (excepcionalmente entre 15 e $35 \mathrm{~mm}$ ). Por sua vez, os fenocristais de quartzo possuem seções arredondadas atingindo dimensões que variam entre 2 e $6 \mathrm{~mm}$, sendo comum, ainda, a ocorrência em agregados formando textura glomeroporfirítica.

Nessa variedade, os cristais de $\mathrm{Qz}_{1}$ mostram frequentemente sinais de corrosão (Figura 6D), resultando em baías preenchidas por microclínio, ocasionalmente acompanhada pela biotita. Em estágios mais avançados de desequilíbrio, os cristais de $\mathrm{Qz}_{1}$ apresentam seções grosseiramente arredondadas indicando que são xenocristais derivados do magma granítico e que foram parcialmente dissolvidos (Figura 6E). Isso sugere que o processo de magma mingling foi envolvido na formação dos EGp. Os grãos de $\mathrm{Qz}_{2}$ ocorrem na matriz, com dimensões variando entre 0,2 e $0,5 \mathrm{~mm}$, análogas às da segunda geração de feldspatos, designados $\mathrm{Pl}_{2} \mathrm{e}$ $\mathrm{Mc}_{2}$. Ocorrem geralmente como grãos intersticiais ou inclusos nas bordas dos fenocristais de feldspatos, resultando em um aspecto poiquilítico ou marcando o crescimento do $\mathrm{Mc}_{2}$ (Figura 6B).

Os cristais de plagioclásio podem ser distinguidos, com base em suas relações texturais, morfologia, maclas e inclusões, em dois tipos. Suas composições também divergem, embora possa haver passagem gradual entre eles. O plagioclásio mais precoce $\left(\mathrm{Pl}_{1}\right)$ é mais cálcico, de composição oligoclásio cálcico $\left(\mathrm{An}_{24}\right)$, podendo chegar à andesina sódica $\left(\mathrm{An}_{30}\right)$ nas porções mais centrais, e de oligoclásio sódico $\left(\mathrm{An}_{16-11}\right)$ 

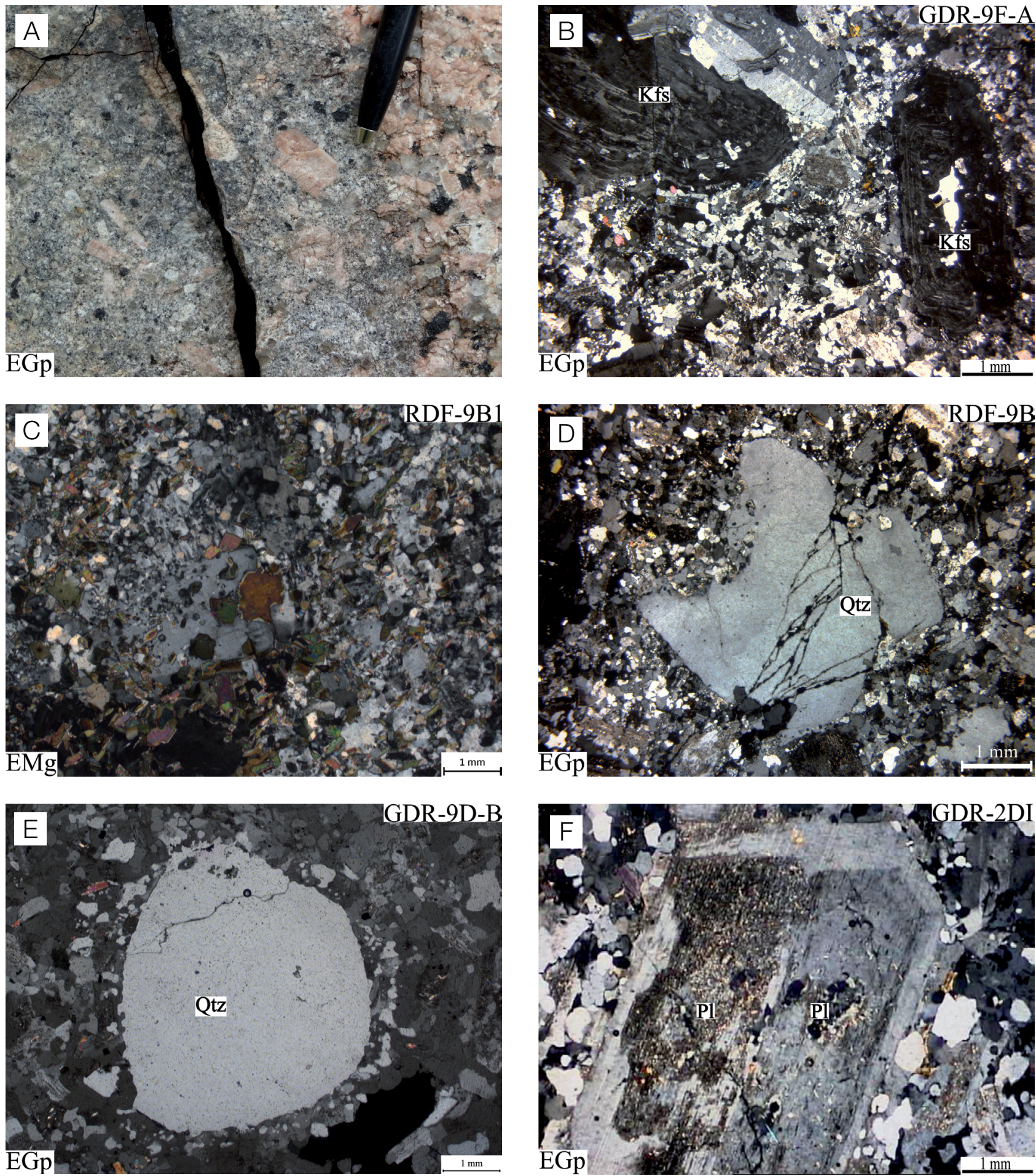

EGp: enclaves de granito porfirítico; EMg: enclaves microgranulares; Kfs: k-feldspato; Qtz: quartzo; PI: plagioclásio.

Figura 6. Aspectos meso e microscópicos dos enclaves microgranulares e porfiríticos: $(A)$ enclave porfirítico com fenocristais de feldspatos mostrando evidências de interação com o magma biotita monzogranito heterogranular; (B) fenocristais de feldspatos com linhas de crescimento e com inúmeras inclusões quartzo nas zonas mais externas; (C) aspecto geral do enclave microgranular em que se destacam a granulação fina e a maior concentração de biotita em relação aos enclaves de granito porfirítico; (D) quartzo parcialmente corroído com desenvolvimento de baías preenchidas por microclínio; (E) xenocristal de quartzo provavelmente derivado do magma granítico parcialmente dissolvido; (F) plagioclásios com feições de synneusis (Vance, 1965) ou de epitaxia (Dowty, 1980). 
a albita $\left(\mathrm{An}_{6}\right.$ até $\left.\mathrm{An}_{0}\right)$, nas bordas. Assemelha-se textural e composicionalmente ao plagioclásio $\left(\mathrm{Pl}_{1}\right)$ presente nas fácies menos evoluídas dos maciços Jamon (Dall'Agnol et al., 1999b), Musa (Gastal, 1987), Redenção (Oliveira et al., 2005, 2009) e Bannach (Almeida et al., 2006), embora os agregados sejam menos frequentes. Os cristais de plagioclásio desses agregados frequentemente apresentam relações que podem ser interpretadas como feições de synneusis (Vance, 1965) ou de epitaxia (Dowty, 1980) (Figura 6F), além daquelas do tipo rapakivi. Por vezes, a alteração diferenciada (descalcificação) deixa transparecer um zoneamento oscilatório. É marcante também a associação desses agregados com as maiores concentrações de minerais máficos, onde se observam intensa cloritização da biotita, presença expressiva de fluorita, maior desenvolvimento dos opacos e maior quantidade de zircão. $\mathrm{O} \mathrm{Pl}_{2}$, por sua vez, está presente apenas na matriz e sua composição é próxima dos cristais que ocorrem nas fácies $\mathrm{BMzH}$ e $\mathrm{BMzE}$ - oligoclásio sódico $\left(\mathrm{An}_{13}\right)$ na maior parte do cristal e varia para albita $\left(\mathrm{An}_{9-3}\right)$ nos bordos, podendo chegar até $\mathrm{An}_{0}$.

\section{Ordem de cristalização das fases minerais}

A história de cristalização dos minerais das fácies que constituem o GrMj foi proposta a partir das características texturais dos minerais e estudo das inclusões, além da relação entre os minerais primários e suas transformações tardi e pós-magmáticas. A cristalização do $\mathrm{GrMj}$ iniciou-se com a separação dos minerais acessórios primários (opacos, apatita e zircão), os quais se apresentam idiomórficos e ocorrem como inclusões no plagioclásio mais cálcico, microclínio e, mais comumente, nos minerais máficos. Tais evidências indicam o caráter precoce desses minerais, antecedendo os demais na ordem de cristalização. A ausência de corrosão nos minerais félsicos essenciais indica que não houve mudanças bruscas nas condições de cristalização, como ocorre nas variedades porfiríticas. Esse aspecto, a escassez de inclusões mútuas nesses minerais félsicos, as maiores dimensões deles e o aspecto hipidiomórfico do quartzo sugerem que esses minerais cristalizaram, em parte, simultaneamente. O plagioclásio mais cálcico, representado pelos núcleos corroídos, é o mais precoce, enquanto a cristalização das zonas mais sódicas, que contém ocasionalmente inclusões de biotita e quartzo, dá-se nos estágios tardios, após o início da cristalização de quartzo e microclínio. Seus frequentes agregados, com alguns cristais exibindo relações de Synneusis (Vance, 1965), são indicativos de que esses plagioclásios mais cálcicos cristalizaram a partir de um magma ainda altamente líquido (baixa razão cristal/líquido). A seguir, iniciou-se a cristalização do $\mathrm{Qz}_{1}$, que em algumas fácies constituem agregados de grãos, indicando que, do mesmo modo que o $\mathrm{Pl}_{1}$, a sua cristalização começou a partir de um magma dominantemente líquido. Quando ocorre associado aos agregados máficos, aparece como cristais de menores dimensões e com um aspecto intergranular, feições indicativas de sua cristalização mais tardia. As formas menos automorfas do $\mathrm{Mc}_{1}$, em relação ao $\mathrm{Pl}_{1}$ e ao $\mathrm{Qz}_{1}$, indicam que o $\mathrm{Mc}_{1}$ começou a cristalizar após estes, mas ainda em um momento em que havia líquido suficiente para permitir o crescimento livre dos cristais. A relação com o $\mathrm{Pl}_{1}$ é reforçada pelo fato de que o $\mathrm{Mc}_{1}$ geralmente possui inclusões deste mineral. $\mathrm{O}$ fato de $\mathrm{o}$ $\mathrm{Mc}_{1}$ parecer estar "corroendo" os cristais de $\mathrm{Pl}_{1}$ pode ser atribuído a reequilíbrios subsolidus desses minerais.

A allanita provavelmente iniciou a sua cristalização antes da biotita, pois é normalmente encontrada como inclusões neste mineral. A titanita aparece mais frequentemente com formas anédricas, associada aos agregados de minerais máficos, porém nas porções externas deles, ou constituindo uma coroa envolvendo os opacos, o que indica claramente a sua formação relativamente tardia. Já a biotita certamente cristalizou após apatita, zircão e opa$\cos$, haja vista as suas relações de inclusão. Não aparece como inclusão nos núcleos mais cálcicos do plagioclásio, sendo, porém, frequentemente inclusa nas suas bordas mais sódicas e, bem menos, no $\mathrm{Qz}_{1}$ e no $\mathrm{Mc}_{1}$. Esses fatos evidenciam que a biotita começou a cristalizar após o plagioclásio (na $>16)$. O estudo experimental do hornblendabiotita-monzogranito do Granito Jamon (Dall'Agnol et al., 1999 c) indica que a mica inicia sua cristalização a temperaturas relativamente mais baixas, sendo, portanto, tardia na cristalização. É provável que a cristalização da biotita se superponha em boa parte com a dos constituintes félsicos essenciais.

A albita intergranular está relacionada à ação de soluções tardias ou a exsoluções ocorridas entre os feldspatos (Smith, 1974; Phillips, 1974). As transformações pós-magmáticas estão representadas pela geração de minerais secundários, geralmente acompanhadas pela descalcificação do plagioclásio e pela transformação da biotita (cloritização), evidenciando a maior participação das soluções tardias nos processos evolutivos do GrMj.

\section{GEOQUÍMICA}

\section{Introdução}

Os resultados geoquímicos discutidos a seguir foram obtidos a partir da análise química em rocha total de 19 amostras representativas das diferentes fácies do GrMj (Tabela 3). As análises foram realizadas no Laboratório ACME Analytical Laboratories LTDA, onde os elementos maiores e menores foram analisados por ICP-ES, enquanto os elementos traço e terras raras foram analisados por ICP-MS. 
Erros analíticos e procedimentos detalhados podem ser consultados no site da empresa.

Para efeito de comparação e melhor compreensão da origem dos enclaves associados ao $\mathrm{GrMj}$, foram plotados dados dos EMg do Granito Qianshan, localizado no nordeste do Cráton China na Península Liaodong (Yang et al., 2006). Eles são representantes de um magmatismo máfico ligados ao granito tipo-A Qianshan, similar ao proposto para o $\mathrm{GrMj}$.

Tabela 3. Composição química do Granito Marajoara e enclaves associados.

\begin{tabular}{|c|c|c|c|c|c|c|c|c|c|c|c|c|c|c|c|c|c|c|c|}
\hline \multirow[b]{2}{*}{ Amostras } & \multicolumn{3}{|c|}{ EMg } & \multicolumn{6}{|c|}{ EGp } & \multicolumn{5}{|c|}{$\mathrm{BMzH}$} & \multicolumn{5}{|c|}{ BMzE } \\
\hline & $\begin{array}{l}\text { RDF } \\
9 B 2\end{array}$ & $\begin{array}{c}\text { RDF } \\
\text { 9BL2 }\end{array}$ & $\begin{array}{l}\text { RDF } \\
9 B 1\end{array}$ & $\begin{array}{c}\text { GDR } \\
9 B\end{array}$ & $\begin{array}{c}\text { RDF } \\
14 B L\end{array}$ & $\begin{array}{c}\text { GDR } \\
2 \mathrm{D}\end{array}$ & $\begin{array}{l}\text { RDF } \\
14 B\end{array}$ & $\begin{array}{c}\text { RDF } \\
\text { 9BL3 }\end{array}$ & $\begin{array}{c}\text { RDF } \\
\text { 9BL1 }\end{array}$ & $\begin{array}{c}\text { GDR } \\
9 A\end{array}$ & $\begin{array}{c}\text { GDR } \\
3\end{array}$ & $\begin{array}{c}\text { GDR } \\
2 \mathrm{~A}\end{array}$ & $\begin{array}{c}\text { RDF } \\
8 \\
\end{array}$ & $\begin{array}{c}\text { RDF } \\
9 A\end{array}$ & $\begin{array}{c}\text { GDR } \\
7\end{array}$ & $\begin{array}{c}\text { GDR } \\
6\end{array}$ & $\begin{array}{c}\text { RDF } \\
11\end{array}$ & $\begin{array}{c}\text { GDR } \\
5 A\end{array}$ & $\begin{array}{c}\text { RDF } \\
2 \\
\end{array}$ \\
\hline $\mathrm{SiO}_{2}$ & 62,88 & 65,41 & 68,24 & 70,92 & 72,05 & 72,27 & 72,33 & 72,51 & 72,96 & 72,97 & 73,21 & 73,65 & 73,69 & 74,64 & 75,26 & 75,46 & 75,72 & 76,00 & 76,27 \\
\hline $\mathrm{TiO}_{2}$ & 0,26 & 0,29 & 0,18 & 0,25 & 0,26 & 0,22 & 0,27 & 0,25 & 0,24 & 0,17 & 0,15 & 0,17 & 0,17 & 0,15 & 0,05 & 0,05 & 0,05 & 0,05 & 0,05 \\
\hline $\mathrm{Al}_{2} \mathrm{O}_{3}$ & 18,30 & 16,64 & 15,60 & 13,89 & 14,16 & 13,45 & 13,95 & 13,73 & 13,70 & 12,96 & 13,03 & 12,84 & 13,77 & 13,03 & 12,78 & 12,95 & 13,10 & 12,56 & 13,03 \\
\hline $\mathrm{Fe}_{2} \mathrm{O}_{3}$ & 3,96 & 4,03 & 2,88 & 1,97 & 2,02 & 1,73 & 2,20 & 2,11 & 2,12 & 1,44 & 1,35 & 1,44 & 1,36 & 1,44 & 0,80 & 0,76 & 0,88 & 0,78 & 0,80 \\
\hline $\mathrm{MnO}$ & 0,14 & 0,16 & 0,11 & 0,07 & 0,07 & 0,06 & 0,07 & 0,07 & 0,07 & 0,04 & 0,05 & 0,05 & 0,04 & 0,04 & 0,07 & 0,07 & 0,07 & 0,04 & 0,05 \\
\hline $\mathrm{MgO}$ & 1,81 & 1,59 & 1,28 & 0,38 & 0,38 & 0,30 & 0,43 & 0,39 & 0,38 & 0,20 & 0,18 & 0,21 & 0,19 & 0,20 & 0,02 & 0,02 & 0,02 & 0,02 & 0,02 \\
\hline $\mathrm{CaO}$ & 1,56 & 1,32 & 1,05 & 1,33 & 1,32 & 1,17 & 1,42 & 1,26 & 1,32 & 0,87 & 0,81 & 0,92 & 0,87 & 0,93 & 0,39 & 0,12 & 0,41 & 0,11 & 0,30 \\
\hline $\mathrm{Na}_{2} \mathrm{O}$ & 5,63 & 4,74 & 4,44 & 3,82 & 3,96 & 3,69 & 3,89 & 3,78 & 3,69 & 3,65 & 3,51 & 3,61 & 3,84 & 3,75 & 4,03 & 3,98 & 4,39 & 3,90 & 4,13 \\
\hline $\mathrm{K}_{2} \mathrm{O}$ & 4,91 & 4,82 & 5,37 & 4,64 & 4,90 & 4,51 & 4,48 & 4,76 & 4,61 & 4,68 & 4,94 & 4,59 & 4,92 & 4,91 & 4,31 & 3,99 & 4,43 & 4,29 & 4,53 \\
\hline $\mathrm{P}_{2} \mathrm{O}_{5}$ & 0,07 & 0,08 & 0,05 & 0,07 & 0,07 & 0,06 & 0,07 & 0,08 & 0,07 & 0,04 & 0,04 & 0,04 & 0,03 & 0,03 & 0,01 & 0,02 & 0,01 & 0,01 & 0,01 \\
\hline PF & 0,30 & 0,80 & 0,60 & 1,70 & 0,60 & 1,50 & 0,70 & 0,90 & 0,60 & 1,70 & 1,50 & 1,30 & 1,00 & 0,70 & 1,10 & 1,30 & 0,80 & 1,10 & 0,70 \\
\hline Total & 99,82 & 99,88 & 99,80 & 99,04 & 99,79 & 98,96 & 99,81 & 99,84 & 99,76 & 98,72 & 98,77 & 98,82 & 99,88 & 99,82 & 98,82 & 98,72 & 99,88 & 98,86 & 99,89 \\
\hline $\mathrm{Ba}$ & 300,0 & 322,0 & 249,0 & 609,2 & 709,0 & 561,5 & 569,0 & 671,0 & 672,0 & 401,9 & 430,7 & 414,7 & 463,0 & 415,0 & 16,4 & 15,4 & 18,0 & 23,4 & 20,0 \\
\hline $\mathrm{Rb}$ & 707,0 & 763,1 & 725,8 & 579,3 & 487,9 & 634,2 & 515,1 & 506,5 & 523,4 & 470,1 & 594,8 & 547,9 & 505,0 & 456,4 & 893,2 & 841,9 & 746,5 & 912,1 & 782,2 \\
\hline $\mathrm{Sr}$ & 145,0 & 85,5 & 118,9 & 135,8 & 134,8 & 108,8 & 140,8 & 133,1 & 139,7 & 78,5 & 81,8 & 91,3 & 83,2 & 77,2 & 5,6 & 3,8 & 4,9 & 5,2 & 4,4 \\
\hline $\mathrm{Zr}$ & 173,4 & 193,2 & 131,1 & 174,4 & 175,4 & 172,5 & 187,2 & 184,7 & 186,5 & 146,5 & 133,7 & 147,2 & 126,0 & 128,9 & 100,0 & 103,5 & 89,6 & 112,9 & 87,6 \\
\hline $\mathrm{Nb}$ & 14,6 & 29,0 & 12,6 & 24,1 & 19,0 & 30,2 & 17,6 & 17,5 & 18,0 & 33,4 & 31,7 & 30,7 & 29,9 & 29,0 & 57,1 & 70,9 & 60,9 & 69,5 & 56,7 \\
\hline Y & 18,3 & 29,3 & 17,3 & 42,3 & 35,5 & 48,4 & 27,8 & 30,4 & 28,4 & 72,0 & 66,4 & 51,3 & 90,0 & 47,5 & 104,4 & 29,2 & 99,7 & 26,3 & 52,7 \\
\hline $\mathrm{Ga}$ & 18,7 & 22,0 & 14,4 & 21,4 & 17,9 & 23,5 & 18,6 & 17,7 & 18,6 & 22,9 & 23,4 & 23,1 & 20,8 & 19,0 & 29,1 & 29,2 & 24,7 & 30,5 & 25,2 \\
\hline Sc & 4,0 & 7,0 & 3,0 & 5,0 & 4,0 & 4,0 & 4,0 & 4,0 & 4,0 & 4,0 & 5,0 & 5,0 & 3,0 & 4,0 & 5,0 & 5,0 & 5,0 & 5,0 & 5,0 \\
\hline Th & 14,4 & 28,9 & 12,7 & 28,0 & 25,0 & 29,9 & 23,6 & 24,7 & 26,1 & 31,6 & 37,5 & 33,3 & 27,3 & 35,0 & 51,6 & 43,8 & 39,2 & 47,1 & 44,2 \\
\hline U & 6,9 & 9,6 & 5,4 & 7,4 & 4,7 & 7,2 & 4,3 & 6,5 & 6,1 & 9,3 & 9,7 & 8,0 & 10,3 & 13,2 & 12,4 & 12,6 & 15,7 & 15,6 & 14,2 \\
\hline V & 21,0 & 16,0 & 20,0 & 16,0 & 20,0 & 13,0 & 21,0 & 15,0 & 18,0 & 9,0 & 8,0 & 10,0 & 19,0 & $<8$ & $<5$ & $<5$ & $<8$ & $<5$ & $<8$ \\
\hline Cs & 12,5 & 14,1 & 12,0 & 4,4 & 4,1 & 7,2 & 4,1 & 5,2 & 5,2 & 3,5 & 8,2 & 5,9 & 4,1 & 3,8 & 11,7 & 13,1 & 15,5 & 9,5 & 9,6 \\
\hline $\mathrm{La}$ & 53,3 & 43,0 & 37,4 & 48,9 & 50,3 & 51,9 & 53,6 & 48,0 & 50,6 & 43,4 & 40,8 & 37,3 & 79,6 & 38,6 & 19,3 & 9,1 & 20,8 & 7,8 & 14,0 \\
\hline $\mathrm{Ce}$ & 90,5 & 73,8 & 65,0 & 104,9 & 97,4 & 111,7 & 105,8 & 96,3 & 98,0 & 89,8 & 89,8 & 79,4 & 127,5 & 78,2 & 45,8 & 22,4 & 45,9 & 48,3 & 33,0 \\
\hline $\operatorname{Pr}$ & 9,2 & 7,5 & 6,5 & 11,2 & 10,4 & 11,7 & 11,2 & 9,8 & 10,5 & 9,8 & 9,6 & 8,6 & 18,5 & 8,3 & 5,6 & 2,1 & 5,6 & 2,1 & 3,7 \\
\hline $\mathrm{Nd}$ & 30,2 & 25,6 & 21,7 & 37,9 & 35,0 & 42,1 & 36,4 & 32,5 & 36,4 & 34,2 & 34,8 & 30,4 & 63,1 & 28,4 & 20,1 & 5,8 & 20,4 & 6,7 & 12,3 \\
\hline Sm & 4,2 & 3,8 & 3,1 & 6,7 & 5,7 & 7,4 & 5,8 & 32,5 & 6,0 & 6,9 & 6,9 & 6,3 & 12,2 & 5,7 & 5,3 & 1,3 & 4,8 & 1,5 & 2,8 \\
\hline Eu & 0,7 & 0,5 & 0,6 & 0,7 & 0,6 & 0,7 & 0,7 & 0,6 & 0,7 & 0,6 & 0,5 & 0,5 & 1,0 & 0,5 & 0,1 & 0,1 & 0,1 & 0,1 & 0,1 \\
\hline $\mathrm{Gd}$ & 3,2 & 3,4 & 2,7 & 5,0 & 4,9 & 5,9 & 4,5 & 4,3 & 4,6 & 7,1 & 6,0 & 5,3 & 10,8 & 5,2 & 5,5 & 1,4 & 5,9 & 1,3 & 3,4 \\
\hline $\mathrm{Tb}$ & 0,5 & 0,5 & 0,4 & 1,0 & 0,8 & 1,0 & 0,7 & 0,7 & 0,7 & 1,3 & 1,2 & 1,0 & 1,9 & 1,0 & 1,2 & 0,4 & 1,2 & 0,4 & 0,7 \\
\hline Dy & 2,4 & 3,2 & 2,1 & 5,3 & 4,5 & 6,2 & 3,9 & 4,0 & 4,2 & 8,7 & 7,7 & 6,6 & 11,3 & 6,3 & 8,6 & 2,9 & 8,7 & 3,0 & 5,3 \\
\hline $\mathrm{Ho}$ & 0,5 & 0,8 & 0,4 & 1,1 & 1,0 & 1,3 & 0,8 & 0,9 & 0,9 & 2,1 & 1,7 & 1,5 & 2,5 & 1,5 & 2,2 & 0,8 & 2,2 & 0,8 & 1,4 \\
\hline $\mathrm{Er}$ & 1,5 & 2,7 & 1,3 & 3,8 & 3,3 & 4,6 & 2,6 & 2,8 & 2,7 & 7,1 & 6,0 & 5,0 & 7,9 & 4,9 & 8,8 & 3,2 & 8,4 & 3,4 & 5,5 \\
\hline $\mathrm{Tm}$ & 0,3 & 0,5 & 0,3 & 0,6 & 0,6 & 0,7 & 0,4 & 0,5 & 0,5 & 1,2 & 1,0 & 0,9 & 1,4 & 0,9 & 1,7 & 0,7 & 1,6 & 0,7 & 1,1 \\
\hline $\mathrm{Yb}$ & 2,0 & 3,6 & 1,9 & 4,2 & 3,7 & 5,0 & 2,9 & 3,3 & 3,3 & 7,9 & 7,1 & 6,4 & 10,2 & 6,2 & 12,9 & 5,2 & 13,2 & 5,2 & 8,3 \\
\hline Lu & 0,4 & 0,6 & 0,3 & 0,7 & 0,6 & 0,8 & 0,5 & 0,5 & 0,5 & 1,3 & 1,2 & 1,0 & 1,6 & 1,1 & 2,2 & 1,0 & 2,3 & 0,9 & 1,5 \\
\hline $\mathrm{Fe}_{2} \mathrm{O}_{3} \mathrm{t}$ & 3,96 & 4,03 & 2,88 & 1,97 & 2,02 & 1,73 & 2,20 & 2,11 & 2,12 & 1,44 & 1,35 & 1,44 & 1,36 & 1,44 & 0,80 & 0,76 & 0,88 & 0,78 & 0,80 \\
\hline $\mathrm{FeO}_{\mathrm{t}} / \mathrm{FeO}_{\mathrm{t}}+\mathrm{MgO}$ & 0,66 & 0,70 & 0,67 & 0,82 & 0,83 & 0,84 & 0,82 & 0,83 & 0,83 & 0,87 & 0,87 & 0,86 & 0,87 & 0,87 & 0,97 & 0,97 & 0,98 & 0,97 & 0,97 \\
\hline A/CNK & 1,05 & 1,08 & 1,04 & 1,01 & 1,00 & 1,03 & 1,01 & 1,01 & 1,02 & 1,02 & 1,03 & 1,02 & 1,04 & 0,99 & 1,06 & 1,17 & 1,03 & 1,12 & 1,06 \\
\hline $\mathrm{Ga} / \mathrm{Al}$ & 1,93 & 2,50 & 1,74 & 2,91 & 2,39 & 3,30 & 2,52 & 2,44 & 2,57 & 3,34 & 3,39 & 3,40 & 2,85 & 2,76 & 4,30 & 4,26 & 3,56 & 4,59 & 3,65 \\
\hline $\mathrm{K}{ }_{2} \mathrm{O}+\mathrm{Na}_{2} \mathrm{O}$ & 10,54 & 9,56 & 9,81 & 8,46 & 8,86 & 8,20 & 8,37 & 8,54 & 8,30 & 8,33 & 8,45 & 8,20 & 8,76 & 8,66 & 8,34 & 7,97 & 8,82 & 8,19 & 8,66 \\
\hline $\mathrm{K} \mathrm{K}_{2} \mathrm{O} / \mathrm{Na}_{2} \mathrm{O}$ & 0,87 & 1,02 & 1,21 & 1,21 & 1,24 & 1,22 & 1,15 & 1,26 & 1,25 & 1,28 & 1,41 & 1,27 & 1,28 & 1,31 & 1,07 & 1,00 & 1,01 & 1,10 & 1,10 \\
\hline $\mathrm{Rb} / \mathrm{Sr}$ & 4,88 & 8,93 & 6,10 & 4,27 & 3,62 & 5,83 & 3,66 & 3,81 & 3,75 & 5,99 & 7,27 & 6,00 & 6,07 & 5,91 & 159,5 & 221,5 & 152,3 & 175,4 & 177,8 \\
\hline$(\mathrm{La} / \mathrm{Yb}) \mathrm{N}$ & 17,72 & 8,02 & 13,50 & 7,86 & 9,10 & 7,02 & 12,48 & 9,94 & 10,38 & 3,69 & 3,88 & 3,96 & 5,29 & 4,20 & 1,01 & 1,18 & 1,07 & 1,02 & 1,14 \\
\hline \#Mg & 47,50 & 43,90 & 46,80 & 34,60 & 35,30 & 36,20 & 36,00 & 35,90 & 36,10 & 35,50 & 34,70 & 34,70 & 33,70 & 34,30 & 33,10 & 33,50 & 33,10 & 33,90 & 34,70 \\
\hline$\sum$ ETR & 198,7 & 169,4 & 143,5 & 231,9 & 218,7 & 251,0 & 229,9 & 236,6 & 219,6 & 221,3 & 214,2 & 190,1 & 349,5 & 186,7 & 139,4 & 56,24 & 141,2 & 82,17 & 93,02 \\
\hline $\mathrm{Eu} / \mathrm{Eu}$ & 0,55 & 0,42 & 0,61 & 0,36 & 0,36 & 0,30 & 0,38 & 0,09 & 0,39 & 0,27 & 0,25 & 0,25 & 0,27 & 0,25 & 0,07 & 0,11 & 0,06 & 0,15 & 0,08 \\
\hline
\end{tabular}

EMg: enclaves microgranulares; EGp: enclaves de granito porfirítico; BMzH: biotita monzogranito heterogranular; BMzE: biotita monzogranito equigranular; elementos maiores \% em peso; elementos traços e terra-rara em ppm. 


\section{Elementos maiores e traços}

As rochas que constituem o $\mathrm{GrMj}$ mostram uma ampla variação no conteúdo de $\mathrm{SiO}_{2}$ (Figura 7), cujos valores ficam entre 62,88 e $76,27 \%$ (Tabela 3). Nota-se, a partir disso, que as amostras pertencentes aos enclaves são as mais empobrecidas em sílica, em que os conteúdos mais baixos de $\mathrm{SiO}_{2}$, são encontrados nas rochas de $\operatorname{EMg}(62,88-68,24 \%)$, enquanto naquelas do EGp são claramente superiores (70,92-72,96\%). Nas demais fácies, os conteúdos de $\mathrm{SiO}_{2}$ apresentam menor variação e valores significativamente mais elevados [BMzH $(72,97-74,64 \%)$ e BMzE $(75,26-76,27 \%)]$. Verifica-se, paralelamente ao aumento de $\mathrm{SiO}_{2}$, trends com nítida diminuição dos teores de $\mathrm{TiO}_{2}, \mathrm{Al}_{2} \mathrm{O}_{3}, \mathrm{Fe}_{2} \mathrm{O}_{3} \mathrm{t}, \mathrm{MgO}$ e $\mathrm{CaO}$ (Figuras 7A a 7E), o que é compatível, em geral, com a diminuição dos conteúdos de minerais máficos e da razão plagioclásio/ microclínio a partir dos enclaves em direção às variedades BMzH e BMzE. Os conteúdos desses óxidos são mais elevados nas amostras do EMg [TiO $(0,18-0,29 \%) ; \mathrm{Al}_{2} \mathrm{O}_{3}(15,60-$ $18,30 \%) ; \mathrm{Fe}_{2} \mathrm{O}_{3} \mathrm{t}(2,88-3,96 \%) ; \mathrm{MgO}(1,28-1,81 \%) ; \mathrm{CaO}$ $(1,05-1,56 \%)]$ e decrescem no sentido das amostras de EGp $\left[\mathrm{TiO}_{2}(0,22-0,27 \%) ; \mathrm{Al}_{2} \mathrm{O}_{3}(13,45-14,16 \%) ; \mathrm{Fe}_{2} \mathrm{O}_{3} \mathrm{t}\right.$ (1,73-2,20\%); $\mathrm{MgO}(0,30-0,43 \%) ; \mathrm{CaO}(1,17-1,42 \%)]$, passando por aquelas da fácies $\mathrm{BMzH}\left[\mathrm{TiO}_{2}(0,15-0,17 \%)\right.$; $\mathrm{Al}_{2} \mathrm{O}_{3}(12,84-13,77 \%) ; \mathrm{Fe}_{2} \mathrm{O}_{3} \mathrm{t}(1,35-1,44 \%) ; \mathrm{MgO}(0,18-$ $0,21 \%)$; $\mathrm{CaO}(0,81-0,93 \%)]$ até as rochas da variedade $\mathrm{BMzE}\left[\mathrm{TiO}_{2}(0,05 \%) ; \mathrm{Al}_{2} \mathrm{O}_{3}(12,56-13,10 \%) ; \mathrm{Fe}_{2} \mathrm{O}_{3} \mathrm{t}(0,76-\right.$ $0,88 \%) ; \mathrm{MgO}(0,02 \%) ; \mathrm{CaO}(0,11-0,41 \%)]$. Já para a razão $\mathrm{K}_{2} \mathrm{O} / \mathrm{Na}_{2} \mathrm{O}$ (Figura $7 \mathrm{~F}$ ), seus valores são baixos para os EMg $(0,87-1,21)$, moderados para os EGp $(1,15-1,26)$ e elevados para as amostras da variedade $\mathrm{BMzH}(1,28-1,41)$, de onde nota-se um acentuado decréscimo até a fácies $\mathrm{BMzE}$ $(1,0-1,10)$. Apesar de a definição aparente de um único trend colinear para o comportamento da maioria desses óxidos, observa-se que existem intervalos ou gaps composicionais que separam todas as variedades identificadas. Tal aspecto indica que a evolução do GrMj não se deu por cristalização fracionada a partir de um único magma, e sim por processos mais complexos em que sua origem estaria relacionada a variações significativas nas composições de seus protólitos e/ ou condições de formação (parâmetros intensivos: $\mathrm{P}, \mathrm{T}$ e $f \mathrm{O}_{2}$ ).

$\mathrm{O} \mathrm{Rb}$ apresenta os conteúdos mais baixos, em geral coincidentes, tanto na variedade $\mathrm{BMzH}(456,40$ - 594,80 ppm) quanto nos EGp (487,90 - 634,20 ppm), enriquecendo-se acentuadamente nas rochas da fácies BMzE (746,50 912,10 ppm) e moderadamente nos $\operatorname{EMg}(707,0$ - 763,10 ppm) (Figura 8A). Comportamento similar aos elementos maiores também é observado para os elementos traços, em que há um decréscimo acentuado nos conteúdos de $\mathrm{Sr}$, Ba e $\mathrm{Zr}$ com o aumento de $\mathrm{SiO}_{2}$ (Figuras $8 \mathrm{~B}, 8 \mathrm{C}$ e $8 \mathrm{D}$ ). As amostras pertencentes aos EGp mostram sempre os valores mais elevados para esses elementos [Sr (108,80 - 140,80 ppm); Ba (561,50 - 709,0 ppm); Zr (172,50 - 187,20 ppm)] em relação às variedades mais evoluídas $\{\mathrm{BMzH}[\mathrm{Sr}(77,20-91,30$ ppm); $\mathrm{Ba}(401,90$ - 463,00 ppm); $\operatorname{Zr}(126,0$ - 147,20 ppm)] e BMzE [Sr (3,80 - 5,60 ppm); Ba (15,40 - 23,40 ppm); Zr $(87,60-112,90$ ppm)]\}. Já os EMg apresentam valores elevados de $\operatorname{Zr}(131,10$ - 193,20 ppm) e $\operatorname{Sr}(85,50$ - 145,0 ppm), coincidentes ou ligeiramente superiores àqueles identificados nos EGp, enquanto para o Ba (249,0 -322,0 ppm), os EMg apresentam conteúdos significativamente inferiores aos do EGp, e situam-se entre aqueles das fácies BMzH e BMzE (Figura 8C).

$\mathrm{Rb}, \mathrm{Y}$ e $\mathrm{Nb}$ apresentam comportamento contrário ao daquele discutido acima para $\mathrm{Ba}, \mathrm{Sr}$ e $\mathrm{Zr}$, onde se nota um aumento de seus conteúdos no sentido das rochas mais evoluídas. Por sua vez, os enclaves são mais empobrecidos em $\mathrm{Y}[\operatorname{EMg}(17,30$ - 29,30 ppm) e EGp (27,80 - 48,40 ppm)] e $\mathrm{Nb}$ [EMg (12,60 - 29,0 ppm) e EGp (17,50 - 24,10 ppm)] em relação à variedade $\mathrm{BMzH}[\mathrm{Y}(47,50-72,0 \mathrm{ppm})$ e $\mathrm{Nb}(29,0$ - 33,40 ppm)] (Figuras 8E e 8F). Nessa direção, a variedade $\mathrm{BMzE}$ apresenta valores ainda mais elevados para $\mathrm{Nb}(56,70$ - 70,90 ppm) e uma significativa dispersão de suas amostras para valores de Y (26,30 - 104,40 ppm), onde pode ser distinguido um grupo com conteúdo elevado $(99,70$ - 104,40 ppm) e outro com valores próximos daqueles atribuídos aos enclaves $(26,30-52,70$ ppm).

\section{Elementos terras raras}

Os dados analíticos dos elementos terras raras (ETR) e suas plotagens correspondentes mostram que as principais variedades que constituem o GrMj apresentam pouco ou nenhum fracionamento de elementos terras raras pesados (ETRP), resultando em padrões horizontalizados (Figura 9A) e baixas razões $\mathrm{La} / \mathrm{Yb}_{\mathrm{N}}$, as quais aumentam ligeiramente da fácies $\operatorname{BMzE}(1,01-1,18)$ para as amostras $\mathrm{BMzH}(3,69-5,29)$ (Tabela 3). No entanto, a primeira fácies mostra um padrão mais fracionado com uma acentuada anomalia negativa de $\mathrm{Eu}\left(\mathrm{Eu} / \mathrm{Eu}^{*}=0,06-0,15\right)$, enquanto esta possui anomalia de Eu moderada $\left(\mathrm{Eu} / \mathrm{Eu}^{*}=0,25-0,27\right)$. Os enclaves apresentam maior fracionamento de ETRP quando comparados às variedades graníticas, sendo que o empobrecimento em ETRP é mais acentuado nos $\mathrm{EMg}\left(\mathrm{La} / \mathrm{Yb}_{\mathrm{N}}=13,08\right)$ em relação aos EGp $\left(\mathrm{La} / \mathrm{Yb}_{\mathrm{N}}=9,46\right)$ (Figura $\left.9 \mathrm{~B}\right)$. O padrão menos fracionado desses enclaves é corroborado pela presença de anomalias negativas de Eu menos pronunciadas do que aquelas observadas nas variedades monzograníticas, que passam de discretas nos $\mathrm{EMg}\left(\mathrm{Eu} / \mathrm{Eu}^{*}=0,53\right)$ a moderadas nos $\mathrm{EGp}\left(\mathrm{Eu} / \mathrm{Eu}^{*}=0,31\right)$. Nos diagramas multielementos, observa-se que todas as variedades mencionadas anteriormente apresentam anomalias negativas para $\mathrm{Ba}, \mathrm{Nb}, \mathrm{Sr}, \mathrm{Pe}$ Ti (Figuras 9C e 9D). No entanto, estas são mais discretas nas amostras pertencentes aos enclaves, e com exceção do $\mathrm{Nb}$, tornam-se mais expressivas na variedade mais evoluída (BMzE), enquanto nas rochas $\mathrm{BMzH}$, tais anomalias tendem 

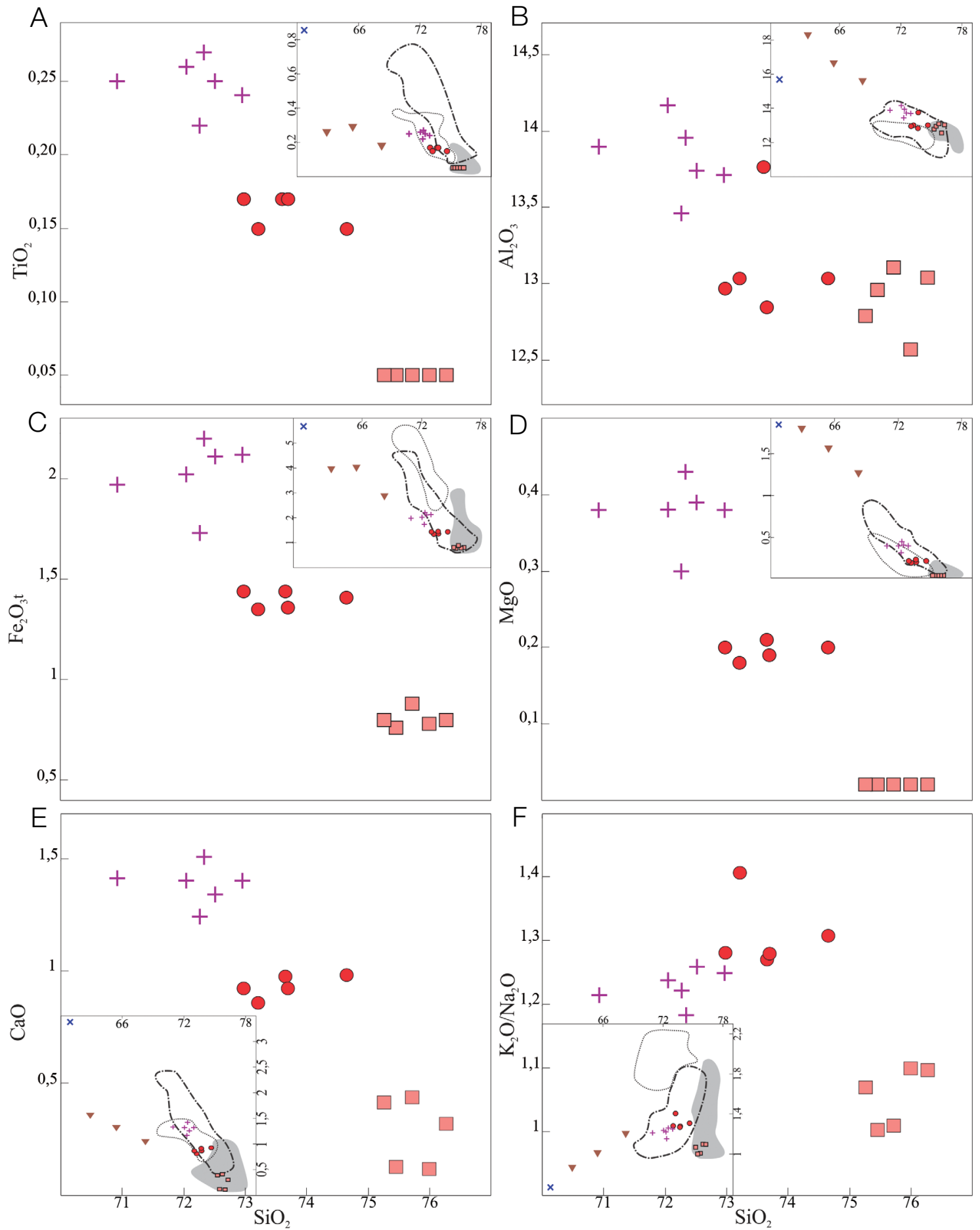

\begin{tabular}{|c|c|c|}
\hline Variedades petrográficas do Granito Marajoara Suítes Paleoproterozoicas da Província Carajás \\
Biotita monzogranito heterogranular & Suíte Serra dos Carajás \\
$\square$ & Biotita monzogranito equigranular & Suíte Jamon \\
$+\quad$ Enclave de granito porfítico & Súte Velho Guilherme \\
$\nabla$ & Enclave microgranular & $\times \quad$ Média dos enclaves do granito Qianshan (Yang et al., 2006) \\
\hline
\end{tabular}

Figura 7. Diagrama de Harker dos elementos maiores do Granito Marajoara. O encarte de cada diagrama ilustra a amplitude de todas as amostras, além de campos comparativos referentes às rochas das diferentes suítes paleoproterozoicas da Província Carajás. 

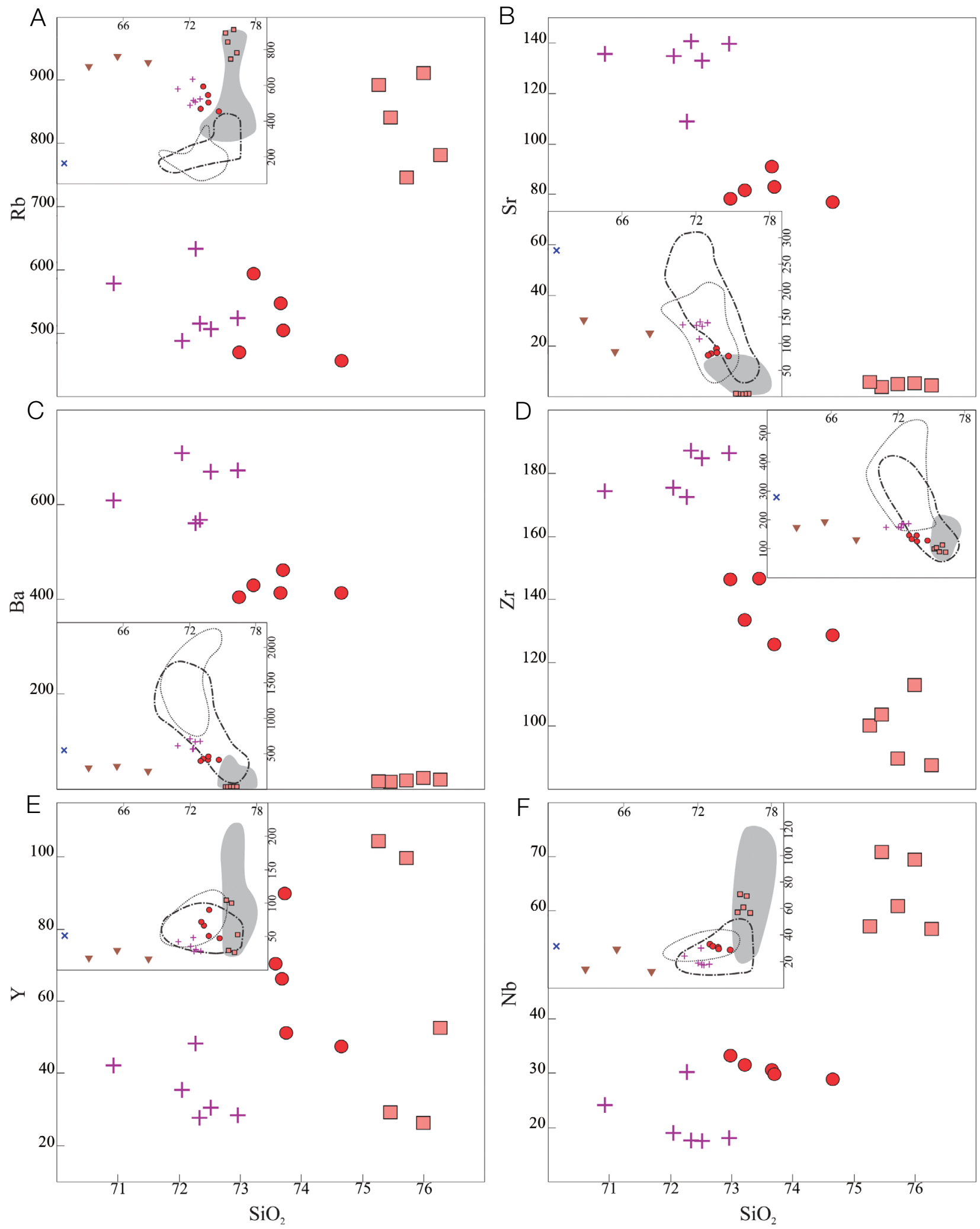

Figura 8. Diagrama de Harker dos elementos traços do Granito Marajoara. Encartes e símbolos assim como na Figura 7. 
a apresentar comportamento transicional, porém mais próximo daqueles identificados nos enclaves.

\section{GEOCRONOLOGIA U-PB}

\section{Introdução}

Para obtenção da idade de cristalização do GrMj foi selecionada a amostra GDR-9F pertencente à variedade $\mathrm{BMzH}$, a qual foi analisada na microssonda SHRIMP II (Sensitive High Resolution Ion Microprobe) do Laboratório de Geocronologia de Alta Resolução do Instituto de Geociências da Universidade de São Paulo (IGc/USP) com os procedimentos analíticos e parte das reduções conduzidas de acordo com Sato et al. (2008), Williams (1998) e Stern (1998). As rochas foram trituradas e os minerais pesados foram separados do pó de rocha usando líquidos pesados (TBE-tetrabromoetano) e um separador magnético Frantz. Os zircões foram selecionados a mão e colocados em uma montagem de epóxi, que foi polida para expor uma seção transversal dos cristais. Foram selecionados e analisados 18 cristais, dos quais cinco forneceram resultados para o cálculo da idade. As concentrações de $\mathrm{U}, \mathrm{Pb}$ e Th foram calibradas de acordo com o zircão padrão Temora (Black et al., 2003). As imagens de catodoluminescência (CL) (Figura 10A) foram obtidas no Laboratório de Geocronologia de Alta Resolução (GEOLAB) do Centro de Pesquisas Geológicas (CPGeo-IGc/ USP). As imagens fornecem informações importantes sobre a morfologia do zircão e a estrutura interna, permitindo a seleção dos melhores locais para análises pontuais, e também representam uma ajuda importante na interpretação dos resultados.

\section{Resultados}

Os dados foram plotados no diagrama de concórdia (Figura 10B) usando o software ISOPLOT 4 (Ludwig, 2003, 2009), e a seleção de cristais considerou o máximo conteúdo de chumbo comum de $1,5 \%$ e o erro da razão
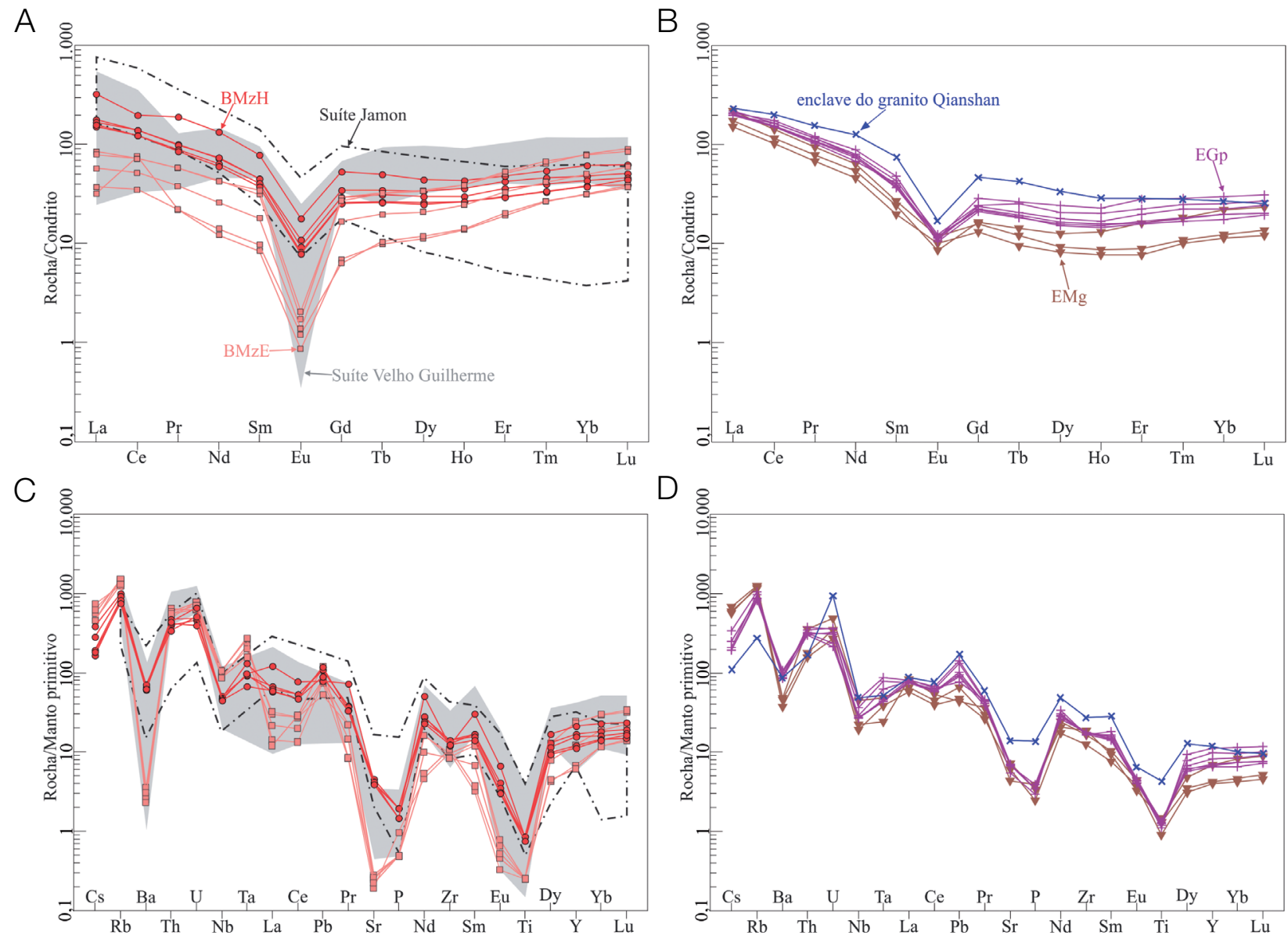

Figura 9. Diagrama de elementos terra-rara do Granito Marajoara: (A) e (C) normalizados de acordo com o condrito de Evensen et al. (1978); (B) e (D) diagramas de multielementos normalizados pelos valores do Manto Primitivo de MacDonough e Sun (1995). Símbolos assim como na Figura 7. 
individual abaixo de 7\%, além da baixa discordância entre grãos (até 5\%), uma vez que a discordância que é comumente observada em diagramas de concórdia demonstra que todos os zircões em dada rocha não podem ser tratados como um único sistema fechado em relação ao sistema U-Pb. Essa pode ser explicada pela perda de $\mathrm{Pb}$ (ou, menos provável, perda de $\mathrm{U}$ ou aumento de $\mathrm{U}$ ou $\mathrm{Pb}$ ) por difusão (por exemplo, Tilton, 1960; Wasserburg, 1963; Wetherill, 1956a, 1956b) ou que as populações são misturas, incluindo zircões de mais de uma idade (por exemplo, Gebauer e Grünenfelder, 1979; Sommerauer, 1974; Steiger e Wasserburg, 1966) ou ainda que os grãos individuais são compostos, incluindo zonas que cresceram em duas ou mais vezes (por exemplo, Black et al., 1986, Kinny et al., 1988). As imagens de catodoluminescência dos cristais utilizados para o método U-Pb SHRIMP mostram fraturas e pequenas inclusões irregulares, a maioria dos grãos exibe zoneamento oscilatório concêntrico, embora o zoneamento do setor seja relativamente comum. As imagens mostraram também que os cristais de zircão não apresentam núcleos herdados onde os grãos de zircão são euédricos a subédricos, de médio a longo, com terminações piramidais que, por vezes, podem ser arredondados e ter tamanhos variáveis, em torno de $70-300 \mu \mathrm{m}$ de comprimento e $40-200 \mu \mathrm{m}$ de largura. Além disso, a faixa restrita de razões $\mathrm{Th} / \mathrm{U}$, combinada com a concordância ou a quase concordância das análises, é uma forte evidência de que esses zircões permaneceram como sistemas químicos fechados desde a cristalização, permitindo, dessa forma, interpretar as idades obtidas como de cristalização desse magma. O diagrama concórdia mostra uma idade de intercepto superior de $1885 \pm 6$ Ma com MSWD de 0,15 , e que é coincidente com as idades de cristalização dos demais granitos paleoproterozoicos da PC, especialmente daqueles da Suíte Jamon (Tabela 4 e Figura 10).

\section{DISCUSSÃO}

\section{Classificação e tipologia}

As duas principais variedades petrográficas identificadas no GrMj possuem, em geral, teores elevados de $\mathrm{Na}_{2} \mathrm{O}+$

Tabela 4. Dados de U-Pb SHRIMP para cristais de zircão da amostra GDR-9F do Granito Marajoara.

\begin{tabular}{|c|c|c|c|c|c|c|c|c|c|c|c|c|}
\hline Furo & $\underset{(\mathrm{ppm})}{U}$ & $\begin{array}{c}\text { Th } \\
\text { (ppm) }\end{array}$ & $\mathrm{Th} / \mathrm{U}$ & $\begin{array}{c}\text { Pb206 } \\
\text { (comm) } \\
\%\end{array}$ & ${ }^{206} \mathrm{~Pb} /{ }^{238} \mathrm{~Pb}$ & $\begin{array}{c}\text { err } \\
(\%) \\
1 \sigma \\
\end{array}$ & ${ }^{207} \mathrm{~Pb} /{ }^{235} \mathrm{~Pb}$ & $\begin{array}{c}\text { err } \\
(\%) \\
1 \sigma \\
\end{array}$ & ${ }^{207} \mathrm{~Pb} /{ }^{206} \mathrm{~Pb}$ & $\begin{array}{c}\text { err } \\
(\%) \\
1 \sigma \\
\end{array}$ & $\begin{array}{c}{ }^{207} \mathrm{~Pb} /{ }^{206} \mathrm{~Pb} \\
\mathrm{Age}\end{array}$ & $\begin{array}{c}\text { err } \\
(\%) \\
1 \sigma \\
\end{array}$ \\
\hline (2.1) & 25 & 30 & 1,25 & $-0,1888$ & 0,3470 & 1,6 & 5,73 & 2,3 & 0,1198 & 1,6 & 1953 & 29 \\
\hline (8.1) & 27 & 38 & 1,44 & 0,3236 & 0,3492 & 1,6 & 5,63 & 2,4 & 0,1153 & 0,6 & 1910 & 31 \\
\hline (10.1) & 101 & 123 & 1,25 & 0,0033 & 0,3436 & 1,2 & 5,51 & 1,6 & 0,1162 & 0,9 & 1889 & 17 \\
\hline (16.1) & 72 & 69 & 0,99 & 0,1461 & 0,3380 & 1,3 & 5,33 & 1,8 & 0,1144 & 1,1 & 1871 & 21 \\
\hline (19.1) & 317 & 230 & 0,75 & 0,0828 & 0,3331 & 1,1 & 5,27 & 1,2 & 0,1147 & 0,5 & 1875 & 9 \\
\hline
\end{tabular}
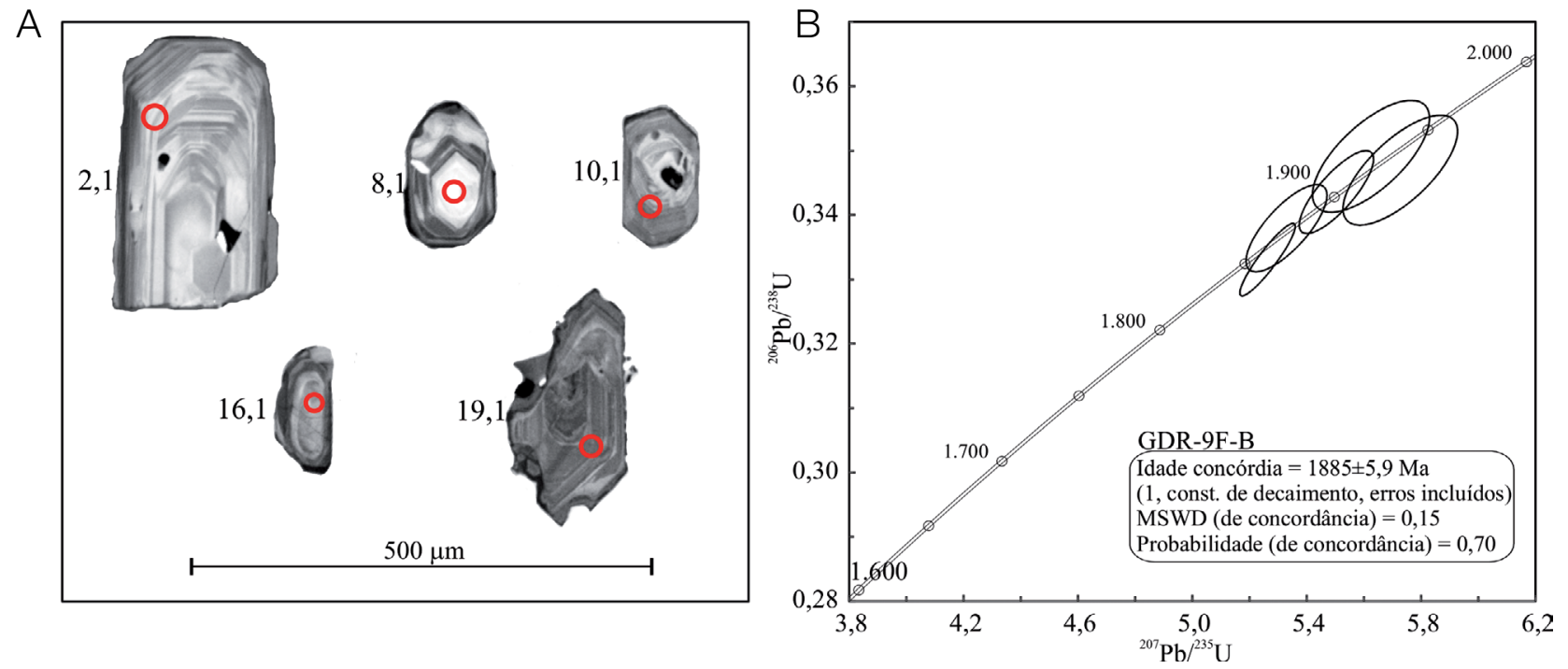

Figura 10. (A) Imagens por catodoluminescência mostrando estruturas internas dos cristais de zircão (pontos analisados em círculo vermelho); (B) diagrama ${ }^{207} \mathrm{~Pb} /{ }^{235} \mathrm{U}$ versus ${ }^{206} \mathrm{~Pb} /{ }^{238} \mathrm{U}$ com os grãos de zircão datados da amostra. 
$\mathrm{K}_{2} \mathrm{O}(7,97-8,76 \%)$, HFSE [Y $(26,30-104,40 \mathrm{ppm})$ e $\mathrm{Nb}(29,0-70,90 \mathrm{ppm})]$, assim como altas razões $\mathrm{FeO}_{\mathrm{t}} /$ $\left(\mathrm{FeO}_{\mathrm{t}}+\mathrm{Mg}\right)(0,86-0,98)$ e Ga/Al $(2,76-4,59)$, e baixas concentrações de $\mathrm{CaO}(0,11-0,93 \%), \mathrm{Al}_{2} \mathrm{O}_{3}(12,56-$ $13,77 \%)$ e $\operatorname{Sr}(3,80-91,30 \mathrm{ppm})$. Diferentemente destas, as amostras dos EMg são marcadas pelas mais baixas concentrações de $\mathrm{Y}(17,30$ - 29,30 ppm) e $\mathrm{Nb}(12,60-$ $29,0)$, baixas razões $\mathrm{FeO}_{\mathrm{t}} /\left(\mathrm{FeO}_{\mathrm{t}}+\mathrm{Mg}\right)(0,66-0,70)$ e teores mais elevados de $\mathrm{CaO}(1,05-1,56 \%), \mathrm{Al}_{2} \mathrm{O}_{3}$ $(15,60-18,30 \%)$ e $\operatorname{Sr}(85,50-145,0 \mathrm{ppm})$. Nas amostras pertencentes aos EGp, esses valores são intermediários entre os dois grupos de rocha.
No diagrama P-Q (Debon e Le Fort, 1983), conforme Figura $11 \mathrm{~A}$, as amostras alinham-se paralelamente ao trend subalcalino e plotam nos campos dos adamelitos (monzogranitos), com exceção das amostras representativas dos EMg que, em geral, apresentam composição entre (quartzo) monzonitítica, indicando seu caráter menos evoluído (Figura 11A). No diagrama A-B (Debon e Le Fort, 1983), nota-se que tais variedades são essencialmente peraluminosas, com exceção de duas amostras, uma da variedade $\mathrm{BMzH}$ e outra do $\mathrm{EGp}$, que apresentam leve tendência metaluminosa (Figura 11B). Nota-se ainda que as amostras dos $\mathrm{EMg}$ apresentam a somatória $\mathrm{Fe}+\mathrm{Mg}+$
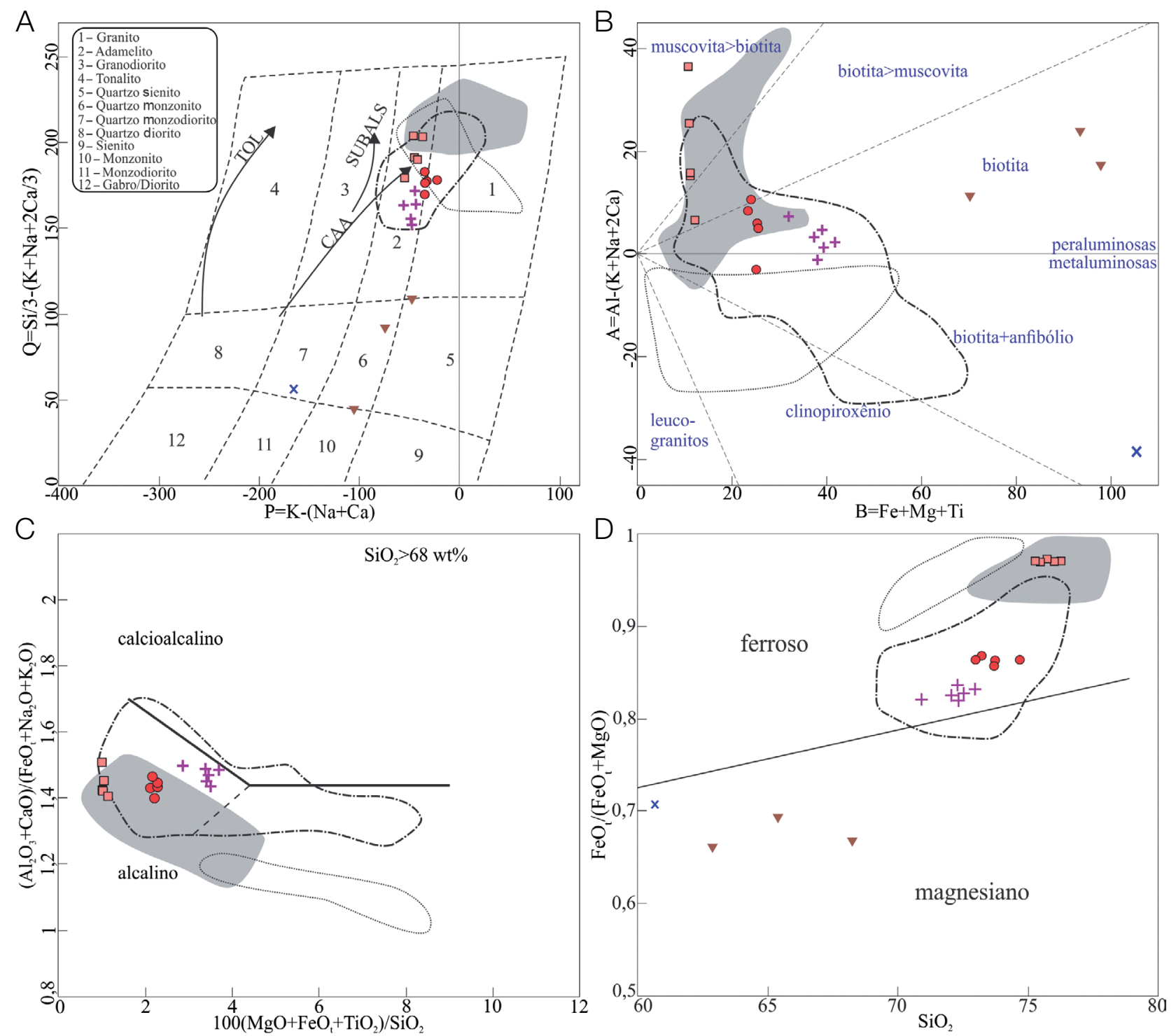

CAA: cálcico-alcalino; SUBALS: subalcalino sódico; TOL: toleítico.

Figura 11. Classificação geoquímica do Granito Marajoara. (A) Diagrama P-Q de Debon e Le Fort (1983); (B) diagrama A-B de Debon e Le Fort (1983); (C) diagrama de definições de séries magmáticas de Sylvester (1989); (D) diagrama de Frost et al. (2001) que distingue granitos ferrosos de magnesianos. Símbolos assim como na Figura 7. 
Ti claramente superior àquelas das demais fácies. Os valores médios da razão $\mathrm{A} / \mathrm{CNK}$ nos enclaves variam de 1,06 $(\mathrm{EMg})$ a 1,01 (EGp); já nas demais variedades graníticas, estão entre 1,02 (BMzH) e 1,09 (BMzE) (Tabela 3). No diagrama de definições de séries magmáticas $100 *(\mathrm{MgO}+$ $\left.\mathrm{FeO}+\mathrm{TiO}_{2}\right) / \mathrm{SiO}_{2}$ versus $\left(\mathrm{Al}_{2} \mathrm{O}_{3}+\mathrm{CaO}\right) /\left(\mathrm{FeO}+\mathrm{K}_{2} \mathrm{O}+\right.$ $\mathrm{Na}_{2} \mathrm{O}$ ) de Sylvester (1989), para amostras com conteúdo de $\mathrm{SiO}_{2}$ superiores a $68 \%$, aquelas que formam o $\mathrm{GrMj}$ demonstram afinidade com rochas alcalinas e cálcico-alcalinas fortemente fracionadas (Figura 11C).

Os diagramas que utilizam padrões de distribuição para elementos traços são utilizados para discriminação de ambientes tectônicos de rochas graníticas. Nesse caso, utilizando o parâmetro de Pearce et al. (1984) com a relação Nb-Y (Figura 12A), nota-se que as amostras das fácies do GrMj concentram-se exclusivamente no campo definido para granitos de ambiente intraplaca (WPG). No entanto, algumas amostras dos enclaves incidem no campo dos granitos de arco ou sin-colisionais (VAG e syn-COLG) como consequência de seus teores relativamente mais baixos para esses elementos. Seus conteúdos relativamente elevados de $\mathrm{SiO}_{2}(>70 \%), \mathrm{Zr}$, $\mathrm{Nb}, \mathrm{Y}, \mathrm{Ga}, \mathrm{ETR}$ e da razão $\mathrm{Fe} / \mathrm{Mg}$, assim como seus baixos conteúdos de $\mathrm{CaO}, \mathrm{Al}_{2} \mathrm{O}_{3}, \mathrm{TiO}_{2}, \mathrm{MgO}, \mathrm{Ba}$ e $\mathrm{Sr}$, aproximam-os dos granitos tipo-A de Whalen et al. (1987), como pode ser visto no diagrama que relaciona a razão $10.000 * \mathrm{Ga} / \mathrm{Al}$ e a somatória $\mathrm{Na}_{2} \mathrm{O}+\mathrm{K}_{2} \mathrm{O}$ (Figura 12B). As amostras do EGp
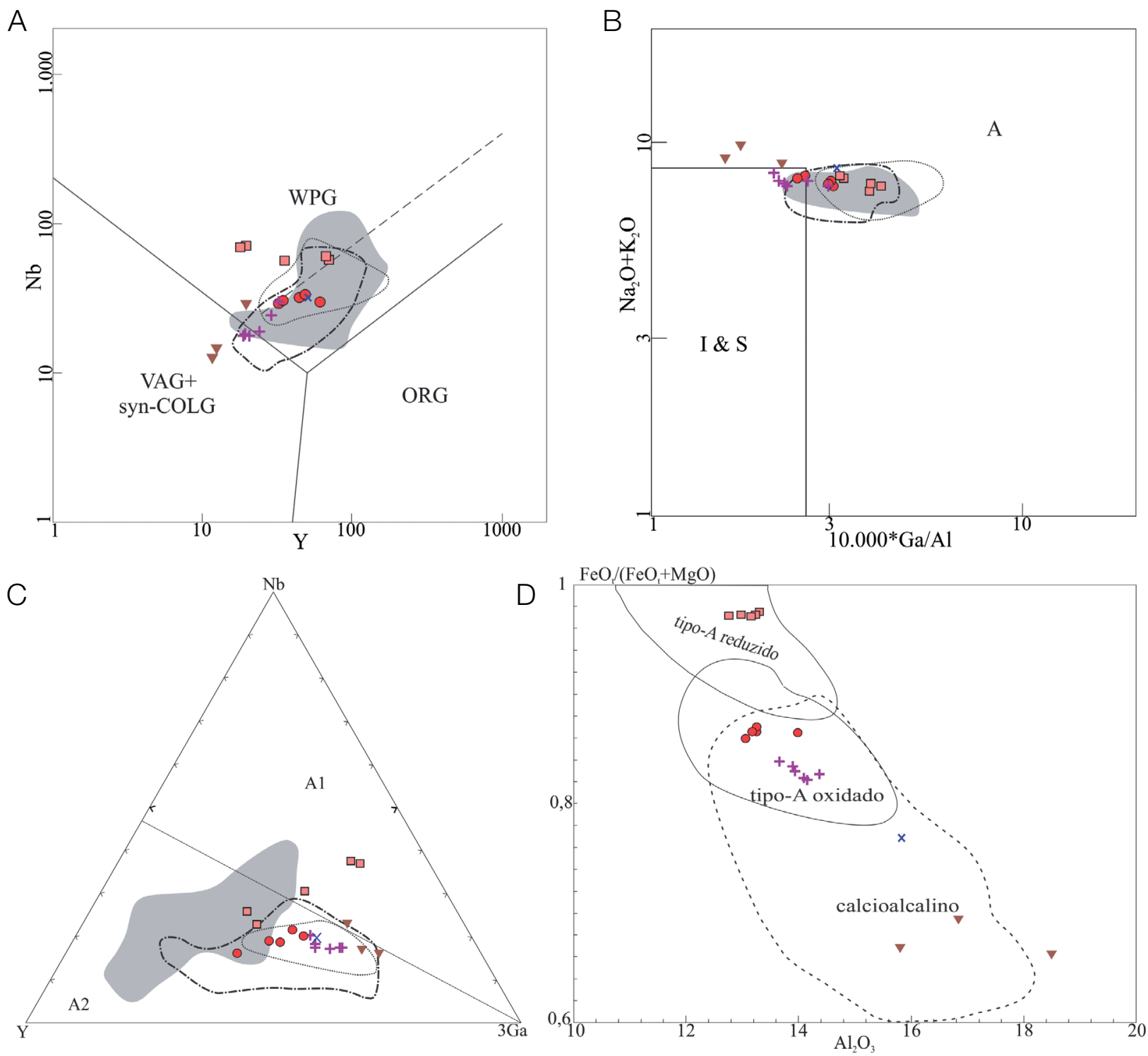

Figura 12. Classificação tectônica do Granito Marajoara: (A) Pearce et al. (1984); (B) Whalen et al. (1987); (C) Eby (1992); (D) Dall'Agnol e Oliveira (2007). Símbolos assim como na Figura 7. 
e da fácies $\mathrm{BMzH}$ apresentam maior variação nas razões $\mathrm{Ga} / \mathrm{Al}$, resultando em um comportamento transicional entre o campo dos granitos tipo-A e aqueles do tipo I e S. No diagrama Nb-Y-3Ga de Eby (1992), que é utilizado para discriminar a afinidade em relação à fonte de granitos, nota-se que o GrMj é afim daqueles do subtipo A2 (Figura 12C). Segundo Eby (2006), granitos do subtipo A2 podem ser formados por diferenciação de toleíto continental, com graus variáveis de interação crustal ou por fusão direta de uma fonte crustal (underplating). A maioria das amostras BMzE incide no campo dos granitos do subtipo A1 por ser comparativamente mais enriquecida $\mathrm{em} \mathrm{Nb}$.

Na classificação proposta por Frost et al. (2001), que utiliza índice de $\mathrm{Fe}^{*}$ para distinguir granitos ferrosos daqueles de afinidade magnesiana, o comportamento da razão $\mathrm{FeO}_{t} /$ $\left(\mathrm{FeO}_{\mathrm{t}}+\mathrm{MgO}\right)$ permite classificar as fácies petrográficas do $\mathrm{GrMj}$, assim como os EGp, como afins dos granitos ferrosos, enquanto as amostras dos EMg incidem no campo dos granitos magnesianos (Figura 11D). No entanto, nota-se, entre as variedades afins dos granitos ferrosos, uma ampla variação nos valores dessa razão, os quais são mais elevados na fácies $\mathrm{BMzE}(\geq 0,97)$ e mais baixos nas amostras de EGp $(\geq 0,82)$, enquanto a fácies $\mathrm{BMzH}$ apresenta valores intermediários $(0,86-0,87)$. Diferentemente do que é observado nessas variedades, as amostras pertencentes ao $\mathrm{EMg}$ apresentam valores da razão $\mathrm{FeO}_{t} /\left(\mathrm{FeO}_{\mathrm{t}}+\mathrm{MgO}\right)$ significativamente mais baixos $(\leq 0,70)$. Essa razão também foi utilizada por Dall'Agnol e Oliveira (2007) para distinguir granitos tipo-A de granitos cálcico-alcalinos, bem como granitos de natureza oxidada daqueles reduzidos. Na Figura 11D, o comportamento distinto para a razão $\mathrm{FeO}_{\mathrm{t}} /\left(\mathrm{FeO}_{\mathrm{t}}+\mathrm{MgO}\right)$ das amostras analisadas permite distingui-las em rochas pertencentes à facies BMzE, que mostram um caráter francamente reduzido; e rochas referentes à variedade $\mathrm{BMzH}$, afins dos granitos oxidados, que são menos ferrosos e mais magnesianos do que o primeiro tipo. Apesar de as amostras dos EGp incidirem no campo dos granitos tipo-A oxidados, mostram também afinidades com o trend dos granitos cálcico-alcalinos fracionados; por sua vez, os EMg são claramente de tendência cálcico-alcalina.

\section{Comparações com corpos análogos da Província Carajás}

Assim como apontado pelos dados geoquímicos, o plúton Marajoara mostra fortes afinidades mineralógicas e texturais com os demais granitos paleoproterozoicos da PC. Em termos petrográficos, são formados por rochas monzograníticas com conteúdo de minerais máficos, em sua maioria, inferiores a $5 \%$. Suas fácies apresentam, ainda, conteúdos significativos de fluorita e allanita, ausência de anfibólio e escassez de titanita magmática. Sob tais aspectos, os plútons estudados mostram fortes afinidades com os granitos das suítes Velho Guilherme e Serra dos Carajás, onde nos primeiros não ocorre titanita magmática e há um enriquecimento em fluorita e topázio, e nos últimos, a titanita é rara ou ausente, sendo fluorita e allanita mais frequentes (Dall'Agnol e Oliveira, 2007). Com respeito aos granitos oxidados da Suíte Jamon, divergem, sobretudo, de suas fácies menos evoluídas, as quais são marcadas pela presença frequente de anfibólio e conteúdo de minerais ferromagnesianos elevados, entre 5 e $20 \%$, onde a titanita magmática é uma fase comum, juntamente com zircão, apatita, magnetita, ilmenita e allanita (Oliveira et al., 2009). No entanto, a ocorrência expressiva de magnetita nas rochas pertencentes à fácies $\mathrm{BMzH}$ e a maior escassez deste mineral na variedade BMzE do GrMj, assim como naquelas dos demais corpos das suítes Vellho Guilherme e Serra dos Carajás, aproxima as primeiras das variedades que representam os estágios finais de construção dos plútons da Suíte Jamon, onde a biotita é o principal mineral ferromagnesiano. Anderson e Morrison (2005) estabeleceram que a razão $\mathrm{FeO}_{\mathrm{t}} /\left(\mathrm{MgO}+\mathrm{FeO}_{\mathrm{t}}\right)$ em rocha total nos granitos da série magnetita de Laurentia tipicamente variam entre 0,80 e 0,88 , enquanto naqueles pertencentes à série ilmenita são mais elevadas $(>0,88)$.

Com base nisso, nota-se nos diagramas que utilizam o índice de $\mathrm{Fe}^{*}\left[\mathrm{FeO}_{t} /\left(\mathrm{FeO}_{\mathrm{t}}+\mathrm{MgO}\right)\right]$ como parâmetro de classificação de granitos, como aqueles de Frost et al. (2001) e Dall'Agnol e Oliveira (2007), que as amostras estudadas incidem tanto no campo dos granitos ferrosos reduzidos (fácies $\mathrm{BMzE}$ com $\mathrm{Fe}^{*} \geq 0,97$ ) quanto naquele dos granitos ferrosos oxidados (fácies $\mathrm{BMzH}$ com Fe* entre 0,86 e 0,87 ), atestando suas afinidades pelos granitos da série ilmenita das suítes Velho Guilherme/Serra dos Carajás ( $\mathrm{Fe}^{*}$ de 0,89 a 0,99$)$ e aqueles da série magnetita da Suíte Jamon ( $\mathrm{Fe}^{*}$ entre 0,83 e 0,94 ), respectivamente (Figuras 11D e 12D). Além disso, as afinidades entre esses grupos de rochas se dão também pelos aspectos mais evoluídos dos granitos reduzidos, os quais apresentam teores, em geral, mais baixos de $\mathrm{Ca}, \mathrm{Sr}, \mathrm{Ti}, \mathrm{Zr}$, Ba e da razão $\mathrm{K}_{2} \mathrm{O} / \mathrm{Na}_{2} \mathrm{O}$ e elevados de $\mathrm{Rb}, \mathrm{Nb}, \mathrm{Y}$ e $\mathrm{Ga}$ em relação àqueles de caráter oxidado (Figuras 7 e 9).

Nesse sentido, no que se refere à amplitude das anomalias negativas de Eu apresentadas pelos corpos das suítes paleoproterozoicas de Carajás, aquelas de amplitude moderada presentes do GrMj pertencem exclusivamente às rochas da variedade $\mathrm{BMzH}$ e são coincidentes com aquelas apresentadas pelos corpos oxidados da Suíte Jamon, as quais são bastante distintas daquelas de amplitude acentuada apresentadas pela fácies $\mathrm{BMzE}$ do $\mathrm{GrMj}$, e que se assemelham, neste aspecto, àquelas atribuídas aos corpos da Suíte Velho Guilherme (Figura 9A). Tal correlação também é mantida pela variação de magnitude das anomalias negativas $\mathrm{Ba}, \mathrm{Sr}$, $\mathrm{P} \mathrm{e}$ Ti das fácies do GrMj (Figura 9C).

Dados de SM e de caracterização de minerais óxidos de Fe-Ti foram obtidos nas principais variedades que constituem o GrMj, com intuito de reforçar suas afinidades petrológicas. 
Tais informações estão sumarizadas no quadro e no histograma de frequência da Figura 13, junto às demais informações sobre as assinaturas magnéticas das suítes paleoproterozoicas de Carajás. Os valores de SM estão relacionados, sobretudo, ao conteúdo modal de magnetita, e que, sob estes aspectos, foi possível distinguir tais suítes com base no grau de oxidação de seus magmas geradores (Dall'Agnoll et al., $2005)$. Estes decrescem da suíte oxidada Jamon $\left(1,05 \times 10^{-3}\right.$ a $54,73 \times 10^{-3} \mathrm{SIv}$ ) passando pela moderadamente reduzida Serra dos Carajás $\left(1,0 \times 10^{-3}\right.$ a 5,0 $\left.010^{-3} \mathrm{SIv}\right)$ até aquela de caráter fortemente reduzido, Velho Guilherme, que detém os valores mais baixos de $\mathrm{SM}\left(<1,0 \times 10^{-3} \mathrm{SIv}\right)$.

De acordo com a terminologia de Ishihara (1977), os granitos da Suíte Jamon pertencem à série magnetita, onde os conteúdos modais de minerais de óxidos de Fe-Ti estão entre 0,5 e $2 \%$ e a magnetita é dominante sobre a ilmenita. Nos granitos das suítes moderada e fortemente reduzidas, essas concentrações são inferiores a 1 e $0,7 \%$, respectivamente, com magnetita escassa. Em especial, nas variedades sienograníticas da Suíte Velho Guilherme, o conteúdo de minerais opacos é normalmente inferior a $0,1 \%$, a magnetita é ausente e elas são classificadas como da série ilmenita.

O estudo de petrologia magnética aplicado às rochas do GrMj mostrou que os valores de SM são variáveis (entre $1,23 \times 10^{-5}$ e $6,46 \times 10^{-3} \mathrm{SIv}$ ), no entanto nota-se que suas fácies apresentam padrão no comportamento de SM contrastantes (distribuição bimodal): na variedade $\mathrm{BMzH}$, os valores de SM ficam entre 2,46 $\times 10^{-4}$ e $6,46 \times 10^{-3}$, enquanto nas rochas BMzE, esses valores são extremamente baixos, entre $1,23 \times 10^{-5}$ e $2,67 \times 10^{-5}$. Nesse sentido, fica claro no histograma de frequência da Figura 13 que, apesar de não existir uma total coincidência entre os limites de seus valores de SM, o comportamento magnético do GrMj se aproxima tanto daquele dos granitos oxidados da Suíte Jamon e das variedades mais magnéticas da Suíte Serra dos Carajás (fácies $\mathrm{BMzH}$ ) quanto dos corpos formados em condições mais reduzidas da Suíte Velho Guilherme (fácies BMzE). Nota-se nas rochas do GrMj aumento nos valores de SM com o acréscimo do conteúdo de minerais opacos, em que a variedade $\mathrm{BMzH}$ apresenta as maiores concentrações $(\geq 0,8 \%)$ e a magnetita é amplamente dominante com ilmenita subordinada. Por outro lado, as rochas BMzE apresentam baixos conteúdos de minerais opacos $(\leq 0,5 \%)$, assim como ausência de magnetita, tendo a ilmenita como o único mineral óxido de Fe-Ti. Tais aspectos sugerem que o GrMj é um plúton formado por injeções de magmas de naturezas distintas, afins dos granitos reduzidos da série ilmenita e daqueles formados em condições oxidadas, da série magnetita.

\section{Considerações sobre a origem do Granito Marajoara}

Diversos modelos petrogenéticos têm sido propostos para a geração de granitos tipo-A, em que sua origem estaria geralmente associada à anatexia crustal provocada por underplating máfico (Dall'Agnol et al., 1999a; Huppert e Sparks, 1988; Rämö e Happala, 1995). Tais modelos adotam diferentes fontes ligadas a processos que variam desde fusão parcial de tonalitos, granodioritos (Anderson, 1983; Anderson e Bender, 1989; Creaser et al., 1991; King et al., 2001) e quartzo-dioritos (Dall'Agnol et al., 1999c) até diferenciação de basaltos toleíticos (Frost e Frost, 1997). Cristalização fracionada de basaltos alcalinos (Eby, 1992) ou de outro magma derivado do manto (Bonin, 1986), e fusão de fontes granulíticas residuais (Clemens et al., 1986; Collins et al., 1982) também têm sido propostas para origem de granitos tipo-A. Embora o modelo de fonte residual possa explicar algumas características dos granitos tipo-A, rochas empobrecidas (granulitos) não teriam composições

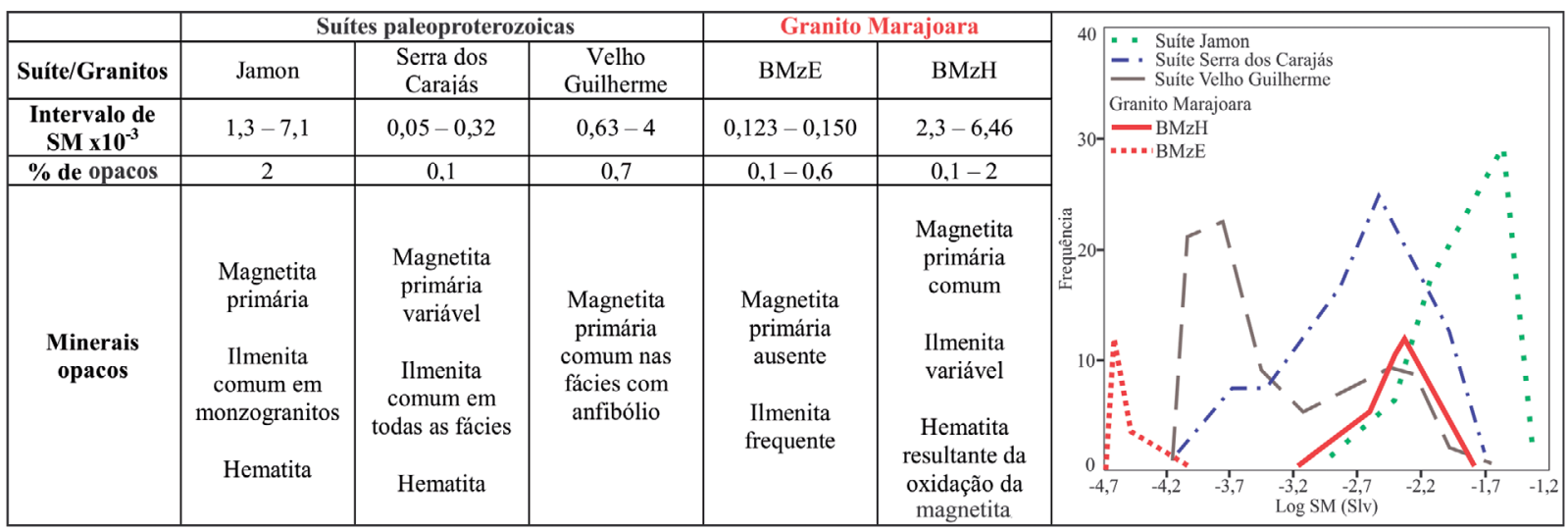

BMzE: biotita monzogranito equigranular; BMzH: biotita monzogranito heterogranular; SM: susceptibilidade magnética.

Figura 13. Quadro e histograma de frequência comparativos mostrando as principais características, em termos de susceptibilidade magnética e minerais óxidos, de Fe-Ti de cada fácies do Granito Marajoara em relação às demais suítes da Província Carajás. Susceptibilidade magnética em Sistema Internacional de unidades de volume. 
adequadas para gerar esse tipo de magma (altos conteúdos de Large Ion Lithophile Elements - LILE (Ba), High Field Strength Elements - HFSE e das razões $\mathrm{Fe} / \mathrm{Mg}$ e $\mathrm{K}+\mathrm{Na} /$ $\mathrm{Ca}$ ), para as quais seria esperado uma assembleia mineral contendo quartzo, biotita, K-feldspato e plagioclásio na fonte (Creaser et al., 1991). Da mesma forma, o modelo de um magma máfico como precursor não parece ser o mais adequado para explicar a origem dos granitos tipo-A, uma vez que suas rochas-fonte deveriam conter minerais acessórios como apatita, zircão e titanita (King et al., 2001). Nesse sentido, basaltos toléticos não podem explicar a origem de granitos oxidados tipo-A da série magnetita (Anderson e Bender, 1989; Anderson e Morrison, 2005; Dall'Agnol et al., 2005), uma vez que, a partir da cristalização fracionada de fundidos toléticos ricos em $\mathrm{Fe}$, serão produzidos magmas reduzidos, por onde seria teoricamente possível explicar a baixa $f \mathrm{O}_{2}$ e as razões $\mathrm{Fe} / \mathrm{Mg}$ mais elevadas dos granitos rapakivi da série ilmenita (Frost e Frost, 1997; Frost et al., 1999).

Um modelo alternativo adotado para a origem de magmas com conteúdo de $\mathrm{H}_{2} \mathrm{O}$ e características geoquímicas compatíveis com aquelas de granitos tipo-A envolve a fusão parcial de granitoides cálcico-alcalinos a uma taxa de $\sim 15$ a $40 \%$ (Creaser et al., 1991). Experimentos de fusão-desidratação com gnaisses tonalíticos magnesianos contendo diferentes proporções de biotita e anfibólio apontam que granitos ferrosos podem ser originados somente em níveis crustais rasos ( $4 \mathrm{kbar}, 950^{\circ} \mathrm{C}$ ), e que, por outro lado, em condições de pressões mais elevadas ( $8 \mathrm{kbar}$ ), o melt produzido é magnesiano e fortemente peraluminoso (Bogaerts et al., 2006; Patiño Douce, 1997; Skjerlie e Johnston, 1993). Para os granitos tipo-A paleoproterozoicos da PC, Dall'Agnol et al. (2005) propuseram modelos análogos a este, e que, de modo geral, adotam fontes crustais arqueanas para as três suítes mencionadas anteriormente. Para os granitos oxidados da série magnetita da Suíte Jamon foi proposto uma fonte quartzo diorítica com 25 - 30\% de fusão (Dall'Agnol et al., 1999c), enquanto para magma formador da Suíte Velho Guilherme, admite-se uma fonte mais enriquecida em K-feldspato, podendo incluir componentes de rochas sedimentares; para os plútons da Suíte Serra dos Carajás atribui-se uma fonte quartzo-feldspática de composição intermediária àquelas das demais suítes ou, ainda, podendo ser similar à fonte da Suíte Velho Guilherme, porém mais máfica, ou resultado de maior grau de fusão parcial.

Os dados petrográficos, geoquímicos e, sobretudo, aqueles de petrologia magnética obtidos para o GrMj indicam que este apresenta fortes afinidades petrogenéticas, tanto com os plútons de caráter reduzido da Suíte Velho Guilherme quanto com os oxidados da Suíte Jamon. A natureza distinta dos magmas formadores das variedades petrográficas que constituem o GrMj traduz tal ambiguidade. A presença marcante de gaps composicionais entre seus conjuntos de amostras indica que tais variedades representam líquidos distintos e que não evoluíram por cristalização fracionada (Figuras 7 e 8). Nesse sentido, a fácies BMzH possui características de granito oxidado coincidentes com aquelas atribuídas aos plútons da Suíte Jamon. Seus magmas iniciaram cristalização sob uma temperatura de $\sim 870^{\circ} \mathrm{C}$ e pressão relativamente alta ( $>6 \mathrm{kbar}$ ), que decrescem gradualmente para temperaturas de $\sim 700^{\circ} \mathrm{C}$ e pressão $3,2 \pm 0,7 \mathrm{kbar}$ nos estágios finais de cristalização/colocação. Estes apresentam, ainda, conteúdos elevados de $\mathrm{H}_{2} \mathrm{O}(4,5$ a 6,5\%) e uma evolução em condições de $f \mathrm{O}_{2}$ relativamente oxidante $(\sim \mathrm{NNO}+0,5)$ (Dall'Agnol et al., 1999b). Os valores elevados de SM (Figura 13) observados na variedade BMzH do $\mathrm{GrMj}$, aliado à presença no estágio magmático da paragênese titanita (idiomórfica) + magnetita + quartzo, indicam que as condições elevadas de $f \mathrm{O}_{2}$ próximas às do tampão HITMQ devem ter reinado durante a formação de tais rochas. As transformações pós-magmáticas desses óxidos, particularmente o processo de martitização da magnetita e a exsolução de hematita nos cristais de ilmenita, sugerem que a $f \mathrm{O}_{2}$ deva ter crescido durante o estágio subsolidus. Desse modo, condições acima do tampão HM foram atingidas localmente para que se alcançassem os parâmetros físico-químicos para o início de tais reações.

A variedade $\mathrm{BMzE}$ do GrMj possui fortes afinidades composicionais com os granitos evoluídos da Suíte Velho Guilherme, e que claramente as distinguem das demais suites paleoproterozoicas. Apresentam as mais altas razões $\mathrm{FeO}_{t} /$ $\left(\mathrm{MgO}+\mathrm{FeO}_{\mathrm{t}}\right)(\geq 0,97)$, ocorrência expressiva de ilmenita e escassez de magnetita, assim como baixos valores de SM, indicando que seus magmas foram gerados em condições mais redutoras do que aquelas atribuídas aos corpos da Suíte Jamon, provavelmente um pouco abaixo do tampão FMQ $\left(f \mathrm{O}_{2} \sim \mathrm{NNO}-1,5\right.$; Dall'Agnol et al., 1999b). Tais rochas foram provavelmente derivadas de líquidos com temperaturas inferiores $\left(<800^{\circ} \mathrm{C}\right)$ àquelas das variedades portadoras de anfibólio da Suíte Velho Guilherme, para as quais se estima que seus magmas tiveram início de cristalização em $\sim 850^{\circ} \mathrm{C}$ com conteúdo de $\mathrm{H}_{2} \mathrm{O}$ entre 4 e $5 \%$ e colocação sob condições de baixa pressão, da ordem de $1,0 \pm 0,5$ kbar (Dall'Agnol et al., 2005). O caráter reduzido essencialmente peraluminoso, o padrão horizontalizado dos ETRP $\mathrm{e}$ as proeminentes anomalias negativas de Eu das amostras $\mathrm{BMzE}$, as quais são inteiramente coincidentes com aquelas desenhadas pelas rochas da Suíte Velho Guilherme, indicam, além de um importante fracionamento de feldspato, que a fonte de seu magma foi mais enriquecida em k-feldspato e mais radiogênica ( \pm pelítica) do que aquela atribuída às rochas do Granito Jamon (quartzo-diorito pobre em si).

As restrições mineralógicas e geoquímicas envolvidas no modelo de uma fonte granulítica empobrecida, os magmas formadores das suítes paleoproterozoicas de Carajás são relativamente enriquecidos $\mathrm{em}_{2} \mathrm{O}(4 \mathrm{a} 6 \%)$, tornando 
improvável a hipótese de que a origem das rochas do GrMj possa estar ligada a uma fonte residual. Alternativamente, entretanto, seria possível ainda explicar a baixa $f \mathrm{O}_{2}$ da variedade BMzE, bom como daquelas de caráter reduzido da Suíte Velho Guilherme, a partir da diferenciação de basaltos toleíticos. No entanto, excetuando a ocorrência de diques associados às suítes paleoproterozoicas, rochas máficas e intermediárias de mesma idade não têm sido descritas em Carajás, que aliado à ausência de faialita e clinopiroxênio nestas rochas, contrasta com o modelo tolético proposto para explicar a origem dos granitos rapakivi do SW dos Estados Unidos (Batólito Shermam), para os quais é atribuída uma temperatura de cristalização de $\sim 900^{\circ} \mathrm{C}$ (Frost et al., 1999). A alta $f \mathrm{O}_{2}$ atribuída à variedade $\mathrm{BMzH}$, análoga àquela dos granitos da série magnetita, sugere que ela foi gerada a partir da fusão parcial de rochas cálcico-alcalinas de natureza oxidada, capaz de produzir líquidos tipo-A em condições acima do tampão FMQ (Skjerlie e Johnston, 1993).

\section{Origem dos enclaves pórfiros}

O GrMj apresenta uma restrita variação composicional, cujos valores de $\mathrm{SiO}_{2}$ (entre 72,97 e 76,27\%) são coincidentes com aqueles das fácies mais evoluídas das demais suítes paleoproterozoicas. Por outro lado, as amostras pertencentes aos enclaves são as mais empobrecidas em sílica, e naquelas pertencentes aos EGp os conteúdos de $\mathrm{SiO}_{2}$ são ligeiramente inferiores $(70,92-72,96 \%)$ ao da fácies $\mathrm{BMzH}$ $(72,97-74,64 \%)$, enquanto os conteúdos significativamente mais baixos desse óxido são encontrados nas rochas de EMg $(62,88-68,24 \%)$. Tal comportamento também é acompanhado pela variação no conteúdo dos demais elementos maiores e traços nessas rochas, produzindo trends lineares, porém descontínuos entre todos os grupos (Figuras 7 e 8). Tais gaps composicionais excluem qualquer relação comagmática entre essas variedades, sugerindo que elas não evoluíram por cristalização fracionada, mas que poderiam ser derivadas de líquidos distintos, ou ainda serem produtos de diferentes graus de fusão a partir de uma mesma fonte. Uma hipótese alternativa seria admitir a influência de processos mais complexos na evolução magmática de algumas variedades, como acumulação e/ou magma mixing (Oliveira et al., 2009). Contudo, é provável que as variedades BMzE e $\mathrm{BMzH}$ sejam produtos de pulsos magmáticos independentes com fontes de natureza distintas. Nesse sentido, o contraste composicional apresentado pelas amostras dos EMg em relação às variedades supracitadas, assim como aos demais granitos tipo-A da PC, é marcado por seus teores elevados de $\mathrm{Al}_{2} \mathrm{O}_{3}, \mathrm{Fe}_{2} \mathrm{O}_{3}$ e $\mathrm{MgO}$, que definem sua afinidade com os granitos cálcico-alcalinos magnesianos. Por sua vez, os EGp apresentam para esses óxidos conteúdos intermediários entre aqueles dos EMg e da variedade $\mathrm{BMzH}$, permitindo que esses óxidos sejam definidos como granitos levemente ferrosos de afinidade tipo-A oxidados e/ou cálcico-alcalinos fracionados (Figura 12D).

O comportamento geoquímico ambíguo dos EGp pode ser atribuído à influência de processos análogos àqueles que envolvem interação de magmas de naturezas distintas (Perugini e Poli, 2012). Nesse sentido, as evidências texturais (desequilíbrio) observadas nesses enclaves (ferrosos) sugerem que houve significativa interação entre o magma de afinidade cálcico-alcalina, representado pelos EMg, com o líquido formador da variedade $\mathrm{BMzH}$. Além disso, alguns fenocristais de feldspatos encontrados nos domínios internos dos EGp provêm do granito hospedeiro (variedade $\mathrm{BMzH}$ ) por meio de um processo de transferência, sugerindo, portanto, um processo de magma mingling (Figuras 2D e 6B). Feições desse tipo são encontradas com relativa frequência na porção central do corpo, indicando coexistência de dois magmas de composições distintas. A ocorrência de enclaves desprovidos de tais feições (EMg) também indica que a atuação de processos de misturas de magmas não foi muito efetiva.

Em ambiente magmático plutônico, os enclaves são um dos indicadores mais importantes da ocorrência de interação magmática. No entanto, para testar a hipótese de origem dos EGp do GrMj a partir da mistura entre os EMg e o líquido $\mathrm{BMzH}$, utilizamos a equação linear descrita por DePaolo (1981) (Equação 1), que, do ponto de vista geoquímico, indica que a mistura de magmas deve produzir trends lineares para qualquer par de elementos maiores ou traços. Para isso:

$X_{M}=X_{A} f+X_{B} \cdot(1-f)$

Em que:

$X_{A}$ e $X_{B}=$ concentrações dos elementos nos membros finais da mistura;

$X_{M}=$ concentração dos elementos traços do magma misturado; $f=$ índice descrito por $[\mathrm{A} /(\mathrm{A}+\mathrm{B})]$.

A partir dessa equação, foram geradas curvas de mistura tendo como membro final $X_{A}$, os EMg, que interagem em diferentes proporções com o membro final $X_{B}$ (granito $\mathrm{BMzH}$ ), em intervalos de $10 \%$. Nos diagramas La/Yb versus $\mathrm{Y} / \mathrm{Nb}$ e Ga/Al versus $\mathrm{Y} / \mathrm{Nb}$ (Figuras $14 \mathrm{~A}$ e 14B), nota-se relação clara entre os dados dos EGp com a curva de mixing modelada, em que eles são coincidentes com uma origem a partir de um processo de mistura com diferentes proporções dos membros finais. Um modelo baseado em mistura binária foi utilizado para explicar a origem dos EGp e pode ser visto por meio dos diagramas de ETR e multielementar normalizados (Figuras 14C e 14D), onde são mostradas as composições dos enclaves e da variedade BMzH. Utilizando-se da equação anterior, foi possível determinar o grau de mistura $(f)$ capaz de gerar um líquido de composição próxima 
daquela dos EGp. O líquido gerado que mostra maior afinidade com os padrões composicionais dos EGp possui $f=$ 0,6 , que significa uma origem a partir da mistura de $60 \%$ do componente $\mathrm{EMg}$ e $40 \%$ do $\mathrm{BMzH}$, indicando maior contribuição do magma magnesiano na formação dessas rochas.

Dados petrográficos e de modelamento geoquímico discutidos anteriormente sustentam a hipótese de que EGp foram originados a partir da interação entre porções do líquido formador dos EMg com o magma granítico que se encontrava em estágio mais avançado de cristalização. No entanto, a origem do magma formador dos EMg pode estar relacionado a processos de reaquecimento associados à chegada de novos pulsos de um magma mais máfico a porções mais profundas da câmara magmática. Por possuir temperatura do solidus mais elevada, o magma mais máfico pode ter provocado fusão e/ou remobilização dos constituintes menos refratários do mush granítico, possibilitando a interação desses magmas em diferentes níveis, como evidenciado pela presença de feições texturais compatíveis com hibridização (desequilíbrio) nos EGp, em um modelo análogo ao sugerido por Paterson et al. (2004).

\section{Significado petrológico dos enclaves microgranulares}

EMg são amplamente distribuídos em plútons graníticos e determinam os fatores condicionantes sobre o papel dos magmas derivados do manto na gênese e na evolução de corpos granitoides. Com base nisso, alguns modelos têm sido propostos para a origem de EMg:

1. mistura entre fusões derivadas do manto e da crosta, a partir da injeção de magma básico em câmaras magmáticas graníticas (Barbarin e Didier, 1992; Didier, 1973);
A

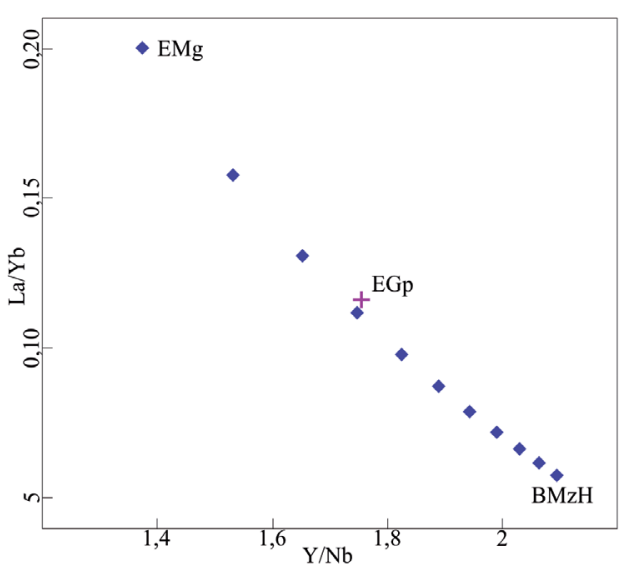

C

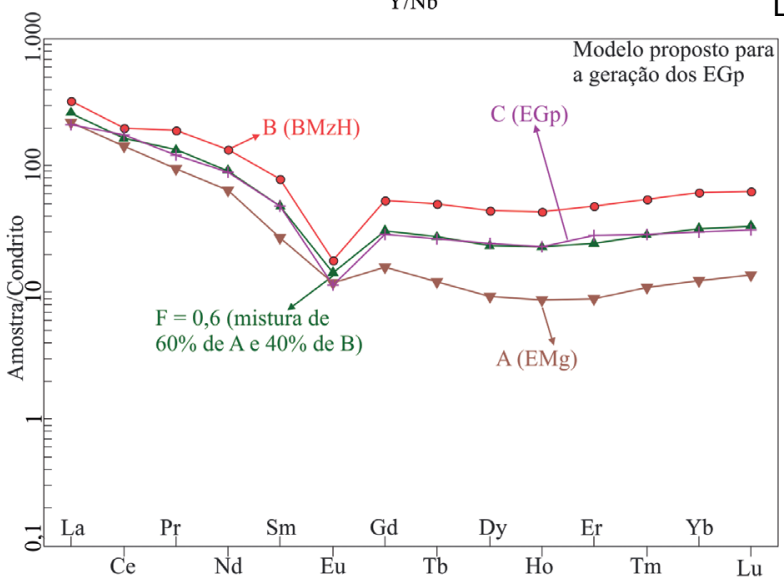

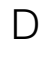

B
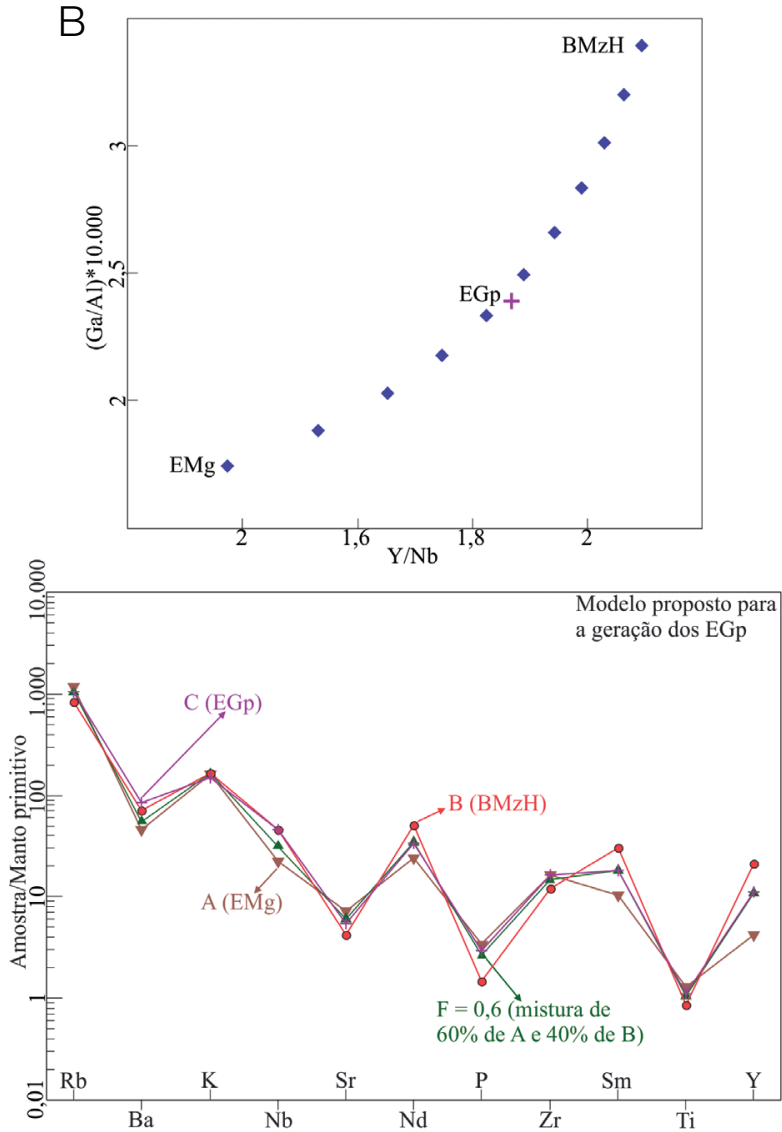

EMg: enclave microgranular; EGp: enclave de granito porfirítico; BMzH: biotita monzogranito heterogranular.

Figura 14. Quantificação da mistura entre os enclaves microgranulares e o Granito Marajoara: (A) e (B) diagramas de variação mostrando a curva em diferentes graus de mistura entre enclaves microgranulares e biotitas monzogranitos heterogranulares; (C) e (D) diagramas de elementos terras raras normalizados de acordo com o condrito de Evensen et al. (1978) e de multielementos normalizados pelos valores do Manto Primitivo de McDonough e Sun (1995), indicando a mistura com contribuição de $60 \%$ dos enclaves microgranulares e $40 \%$ dos biotitas monzogranitos heterogranulares. Símbolos assim como na Figura 7. 
2. representantes de uma porção não hibridizada da fonte do granito ou do resíduo de uma fonte metamáfica (modelo de restito) (White et al., 1999);

3. representantes de cristais cumulados (Dahlquist, 2002; Donaire et al., 2005).

Por outro lado, alguns trabalhos referentes ao estudo sistemático de EMg têm revelado que em parte destes, a composição não é normalmente básica, onde o contraste composicional com o granito hospedeiro pode ser caracterizado como mínimo. Nesse caso, a origem admitida para os EMg félsicos é distinta: Babarin e Didier (1992) sugerem que esses corpos seriam fragmentos pertencentes à borda resfriada do plúton (autólito). Trabalhos mais recentes têm mostrado que esses podem ser utilizados para uma compreensão mais complexa da dinâmica de câmaras magmáticas graníticas do que anteriormente admitido, uma vez que podem representar líquidos composicionalmente modificados durante a interação entre magmas félsico e máfico (Hibbard, 1995; Waight et al., 2007).

Os EMg do GrMj assemelham-se, petrograficamente, à matriz dos EGp, principalmente em porções onde esta é mais homogênea e apresenta poucos xenocristais, no entanto os primeiros são mais primitivos do que os EGp e o granito hospedeiro, distinguindo-se destes por apresentar variação composicional mais restrita, maiores porcentuais modais de biotita e, consequentemente, dos óxidos de Ti, $\mathrm{Ca}, \mathrm{Fe}$ e $\mathrm{Mg}$. As texturas ígneas indicativas de resfriamento rápido observadas nos enclaves do $\mathrm{GrMj}$, além da presença de bordas de resfriamento definindo o contorno desses enclaves e a ocorrência de "megacristais" de bordas corroídas (assimilação) de composição e dimensões análogas às do granito hospedeiro, são evidências consistentes com o mecanismo de injeções de líquidos mais primitivos em câmaras graníticas (Didier, 1973). Tais feições sugerem que esses pulsos de magma máfico, por possuírem temperaturas na curva do solidus mais elevadas $\left(\sim 1.200^{\circ} \mathrm{C}\right)$ em relação ao líquido granítico $\left(\sim 700^{\circ} \mathrm{C}\right)$, solidificaram-se rapidamente (chilling) dentro do mush granítico e se fragmentaram formando bolhas (enclaves). No caso dos EMg, ao contrário do que ocorre nos EGp, a presença de contatos bruscos e a ausência de xenocristais pertencente ao granito hospedeiro aparentemente sugerem que não houve reações em estado líquido entre ambos. Nesse caso, o fato de os dois tipos de enclave identificados no GrMj ocorrerem exclusivamente associados à sua fácies principal (BMzH), indicam que os EMg corresponderiam às porções isoladas do mesmo magma que originou a matriz dos EGp.

Os EMg apresentam número de $\mathrm{Mg}(\mathrm{Mg} \#)$ relativamente elevados $(47,5-43,8)$ e são mais empobrecidos em $\mathrm{SiO}_{2}(62,8-68,2 \%)$, além de possuírem discretas anomalias negativas de $\mathrm{Ba}, \mathrm{Sr}$ e Eu, em relação ao granito hospedeiro (Tabela 3 e Figuras 8A a 8D). Isso indica que um componente com alto conteúdo de $\mathrm{MgO}$ e baixas concentrações $\mathrm{SiO}_{2}$ esteve envolvido na gênese desses enclaves. Tais aspectos geoquímicos são similares ao que é observado nos EMg que ocorrem alojados no Granito Qianshan de afinidade Tipo-A do NE da China (Yang et al., 2006). Estes apresentam valores de Mg\# $(19,7-54,0)$ e conteúdo de $\mathrm{SiO}_{2}(57,5-67,0 \%)$, em geral, coincidentes com aqueles encontrados nos enclaves do GrMj. Tal afinidade também é apontada pelo comportamento dos demais elementos maiores, pelas fortes coincidências de seus padrões ETR (Figura 9B), pelo empobrecimento em $\operatorname{HFSE}(\mathrm{Y}, \mathrm{Ga}, \mathrm{Nb})$ e pelo enriquecimento em $\mathrm{Rb}$ e Zr. Essas características geoquímicas sugerem que o magma que originou os $\mathrm{EMg}$ associados ao Granito de Qianshan foram derivados do manto litosférico enriquecido e modificado por processos de mixing com magmas crustais (Yang et al., 2006). Admitindo-se um modelo análogo para a origem dos $\mathrm{EMg}$ do GrMj, podemos sugerir que a evolução de um sistema progressivo com misturas do tipo mixing e mingling resultou na formação de granitoides híbridos ricos em minerais máficos (biotita), que gradaram para termos mais evoluídos e com xenocristais de feldspatos. Nesse modelo, o magma máfico é introduzido antes do início da cristalização do magma félsico, onde completo mixing pode ocorrer em profundidade e favorecido por convecção, resultando em rochas híbridas homogêneas cálcico-alcalinas, onde os dois componentes originais são indistinguíveis. Processo similar é assumido para a origem dos granitos cálcico-alcalinos de Sierra Nevada (Barbarin, 2005). O maior enriquecimento em Rb dos EMg do GrMj em relação àqueles do Granito Qianshan indica que o processo de contaminação foi mais significativo nos primeiros e que, consequentemente, também seria responsável por seu caráter peraluminoso.

\section{Construção do Granito Marajoara}

\section{Modelo e critérios de ascensão}

A baixa profundidade (ambiente epizonal) em que se deu a colocação dos magmas formadores do GrMj é atestada pelas diferenças de idades entre as rochas encaixantes $(2,87-2,93 \mathrm{Ga})$ e o granito $(1,88 \mathrm{Ga})$ e pelo fato de o plúton truncar abruptamente as foliações regionais, cujos padrões E-W não parecem ser influenciados por ele, o que revela um comportamento rígido das rochas encaixantes $\mathrm{e}$ demonstra o elevado contraste de viscosidade com o magma granítico quando de sua colocação. Além desses aspectos, a forma angulosa dos xenólilos relacionados ao Tonalito Arco Verde e a ausência de orientação tanto do conjunto de enclaves como nas principais variedades graníticas, refletem a ausência de esforços regionais quando da colocação do magma e confirmam tal contraste. Desse modo, é lógico supor um magma ainda com baixa razão cristal/líquido 
quando da colocação, comportando-se como um fluido, estando, portanto, em estado físico e térmico distinto das suas rochas encaixantes.

Apesar da forma grosseiramente circular do GrMj, os contatos, ocasionalmente, em extensos segmentos retilíneos, com algumas reentrâncias angulares, sugerem que o controle de colocação do GrMj se fez por fraturas anteriores à intrusão. Esse controle na estruturação do corpo é reforçado pela coincidência das direções dos principais sistemas de fraturas em seu interior com os principais sistemas de lineamento regionais dominantes (NW, N-S e NE), que muito provavelmente controlaram a sua intrusão. Os dados obtidos sugerem, ainda, que os principais sistemas de fraturamentos estiveram ativos até o final da colocação do maciço, servindo como condutos para líquidos tardios mais evoluídos, responsáveis pela formação de diques félsicos e veios de quartzo.

A controvérsia relacionada ao transporte de magmas félsicos teve início quando alguns trabalhos restringiram a atuação do diapirismo, até então tido como principal (ou único) mecanismo de ascensão, em função de alguns parâmetros físicos limitantes (Cruden, 2005; Olivera et al., 2010; Petford, 1996; Petford et al., 2000). Os argumentos defendem que o diapirismo na crosta era um processo inviável, limitado pela condutibilidade térmica do magma e pela velocidade excessivamente baixa dos diápiros, necessitando considerar uma crosta anomalamente quente para tornar o processo eficiente (Mahon et al., 1988; Marsh, 1982). Considerando suas restrições, o diapirismo parece constituir um mecanismo inviável em crosta rasa, uma vez que as estruturas dúcteis observadas nas rochas encaixantes em torno do plúton não se ajustam àquelas geradas pela passagem de um diápiro em modelos experimentais.

As relações de contato do GrMj com suas rochas encaixantes são análogas àquelas descritas para os demais corpos da Suíte Jamon. A disposição dos plútons graníticos paleoproterozoicos de Carajás ao longo de um cinturão que segue o trend geral definido pelos enxames de diques de diabásio e granito pórfiro, de orientação WNW-ESE a NNW-SSE e coexistentes com os plútons tipo-A, indica que esses plútons foram colocados em um ambiente de tectônica extensional com o esforço seguindo o trend NNE-SSW a ENE-WSW. Conciliando a geometria tabular (lacólitos) inferida aos batólitos da Suíte Jamon (Oliveira et al., 2008) ao comportamento reológico das rochas encaixantes e à influência reduzida ou nula dos esforços regionais durante a colocação do GrMj, é admitido que o transporte do magma se deu por meio de diques. Falhas profundas serviram como canal para ascensão do magma e as descontinuidades tectônicas representariam zonas de fraqueza que favoreceram a colocação em níveis crustais rasos. A tectônica extensional admitida para a colocação do $\mathrm{GrMj}$, assim como para os demais granitos tipo-A da PC, pode ser interpretada como consequência da fragmentação de um supercontinente paleoproterozoico em $\sim 2.0 \mathrm{Ga}$ associada a underplating de magmas mantélicos (Dall'Agnol et al., 2005; Rämö et al., 2002).

\section{Dinâmica da câmara magmática}

A disposição espacial das variedades petrográficas no interior do GrMj mostra uma zonalidade concêntrica similar a estruturas observadas em alguns maciços circunscritos, como o de Rosses (Pitcher e Berger, 1972), da Sierra Nevada (Bateman e Chappell, 1979), Galloway (Stephens e Halliday, 1979), Ambalavayal (Rajesh, 2000) e dos maciços Jamon, Musa e Serra dos Carajás do Cráton Amazônico (Dall'Agnol et al., 1999b; Paradella et al., 1998). Na concepção de alguns autores, os plútons zonados resultam da colocação de uma fase magmática móvel tardia cortando os termos precoces (Oliveira et al., 2008, 2010). No caso dos plútons Redenção e Bannach da PC, estes autores consideram que a evolução desses corpos se deu por meio da amalgamação de pulsos (tabulares) de magmas, e enfatizam a participação de processos de magma mingling na origem desses plútons e que a cristalização fracionada in situ não é o mecanismo dominante para o desenvolvimento do zoneamento. $\mathrm{O}$ modelo de reconstrução desses plútons parte da colocação inicial de um pulso de magma formador das variedades monzograníticas equigranulares, que foi seccionado por granitos anelares esparsamente $\mathrm{e}$ densamente porfiríticos (textura seriada). A forma final dos plútons foi adquirida após a colocação e a expansão de stocks leucograníticos centrais que originaram o padrão concêntrico das fácies (Oliveira et al., 2010).

No modelo de derivação do corpo a partir de dois líquidos distintos, as principais elevações do $\mathrm{GrMj}$, constituídas pela variedade $\mathrm{BMzH}$, representariam o produto de uma intrusão separada daquela que gerou a variedade BMzE, e que apesar de configurarem a estruturação concêntrica do plúton, não sugerem o mesmo padrão de zoneamento mostrado nos demais plútons da Suíte Jamon, onde a porção central deles é ocupada por líquidos mais evoluídos. No caso do $\mathrm{GrMj}$, a fácies $\mathrm{BMzE}$, que ocupa as bordas do corpo, representaria injeções de um líquido mais evoluído, derivado de uma fonte mais radiogênica, enquanto que a fácies $\mathrm{BMzH}$, de caráter menos evoluído, ocorreria na porção central do corpo. A disposição desta, que na porção centro-sul do plúton ocorre como um corpo de forma semicircular que indica a ocorrência de estruturas anelares, sugere que ela foi alojada ao longo de descontinuidades preexistentes e, como sugere a forma, posteriormente à colocação das fácies BMzE. Em referência ao modelo de construção do plúton Redenção, a variedade $\mathrm{BMzH}$ possui notável afinidade petrográfica com a fácies densamente porfirítica (textura seriada) identificada neste maciço, e que delineia estruturas anelares na porção central do batólito (Oliveira et al., 2009), 
ao mesmo tempo que os aspectos texturais da fácies BMzE são análogos aos daqueles identificados na fácies mais evoluída (LMzE) dos granitos Bannach (Almeida et al., 2006) e Redenção (Oliveira et al., 2009). Estas foram interpretadas como líquidos independentes e tardios, colocados em níveis crustais rasos $(\sim 1,0 \pm 0,5 \mathrm{kbar})$ em um sistema de alimentação por diques e construção de plútons tabulares por injeções múltiplas de magma (Oliveira et al., 2010).

Levando em consideração os critérios estabelecidos anteriormente para assumir um modelo de ascensão por diques, podemos sugerir que a construção do GrMj, bem como a disposição de suas fácies, é resultado de:

1. ascensão vertical de magmas através de fraturas e acomodação pela translação ao longo dos planos da foliação regional E-W;

2. posterior mudança do fluxo vertical para um espalhamento lateral do magma, que seria responsável pela forma tabular do plúton, com subsidência do assoalho criando espaço para injeção de pulsos magmáticos sucessivos;

3. expansão in situ da câmara magmática (líquido $\mathrm{BMzE}$ parcialmente cristalizado) em resposta à colocação da variedade $\mathrm{BMzH}$ na porção central do corpo.

Se a criação do espaço por deslocamento lateral foi ineficiente para acomodar novos pulsos de magma, o aumento da pressão na câmara magmática poderia resultar no fraturamento da cúpula da intrusão, com desenvolvimento de fraturas anelares acompanhadas de injeções (expulsão) do magma residente, dando origem à estrutura em forma de arco associada ao líquido BMzH na porção sul do corpo, como resposta à tensão radial (esforço coaxial) induzida pela colocação da variedade $\mathrm{BMzH}$. As injeções de magma máfico, responsáveis pela origem dos enclaves, deram-se durante diferentes fases de cristalização do magma granítico. Os EGp indicam que o magma máfico é introduzido logo após o início da cristalização do granito $\mathrm{BMzH}$, onde o contraste de viscosidade pode ser suficientemente diferente para permitir somente a mistura parcial (mingling). A ausência de tais feições nos EMg é indicativo de que o magma máfico é introduzido quando o magma félsico encontra-se em um estágio mais avançado de cristalização, onde o primeiro foi canalizado para as fraturas precoces. Nesse caso, os EMg representariam partes de diques fragmentados formados por um líquido já hibridizado (mixing) em profundidade.

A ocorrência de cristais disseminados de molibdenita na variedade $\mathrm{BMzH}$, assim como as ocorrências das paragêneses de alteração hidrotermal dos tipos quartzo-sericítica (sericita + clorita + quartzo + pirita + fluorita) e argílica (sericita + hematita + quartzo + argilo-minerais), parece ser resultado da concentração de elementos litófilos na cúpula do GrMj e transferência do magma resultante rico em sílica e voláteis para as estruturas anelares mais rasas durante os últimos estágios de colocação/construção do corpo.

\section{CONCLUSÕES}

As rochas que constituem o GrMj possuem composição essencialmente monzogranítica, excetuando-se seus enclaves. Os EGp apresentam uma composição transicional entre o campo do granodiorito e aquele do monzogranito, enquanto os EMg são essencialmente granodioríticos. $\mathrm{O}$ GrMj é formado de duas fácies petrográficas, nas quais a biotita ocorre como único mineral ferromagnesiano varietal, dispostas em um arranjo concêntrico, como as rochas mais leucocráticas situando-se na periferia do corpo, e aquela de caráter menos evoluído e hospedeira dos enclaves ocupando a porção central do plúton. Tal disposição seria inconsistente com uma evolução por cristalização fracionada (zoneamento normal), como é observada em alguns plútons da Suíte Jamon. Ocasionalmente, a variedade BMzH forma estruturas anelares. A idade U-Pb (SHRIMP) de $1885 \pm 5,9 \mathrm{Ma}$ é interpretada como a idade de cristalização do GrMj, que é concordante com aquela obtida para os demais granitos paleoproterozoicos da PC.

$\mathrm{O} \mathrm{GrMj}$ possui assinatura geoquímica de granitos intraplaca tipo-A, no entanto seus magmas apresentam naturezas claramente distintas. A ocorrência de magnetita e titanita, bem como os altos valores de SM, demonstra que a variedade $\mathrm{BMzH}$ foi formada em condições oxidantes e apresenta afinidades com os granitos da série magnetita e demais granitos tipo-A oxidados da Suíte Jamon. A variedade BMzE apresenta a ilmenita como único mineral óxido de $\mathrm{Fe}-\mathrm{Ti}$, valores ligeiramente mais altos da razão $\mathrm{FeO}_{t} /\left(\mathrm{FeO}_{\mathrm{t}}+\mathrm{MgO}\right)$ e padrão ETR com acentuado fracionamento de $\mathrm{Eu}$, que a distingue dos granitos tipo-A oxidados. Tais rochas são afins dos granitos da série ilmenita e daqueles do tipo-A reduzidos da Suíte Velho Guilherme. As rochas monzograníticas possuem altas razões de $\mathrm{FeO}_{\mathrm{t}} /\left(\mathrm{FeO}_{\mathrm{t}}+\mathrm{MgO}\right)$ e $\mathrm{K}_{2} \mathrm{O} / \mathrm{Na}_{2} \mathrm{O}$, baixos valores de $\mathrm{CaO}$ e $\mathrm{Al}_{2} \mathrm{O}_{3}$ e elevados de $\mathrm{Y}$ e $\mathrm{Nb}$ comparadas aos enclaves, sobretudo daqueles desprovidos de feições de mingling e que apresentam assinatura de magma calcioalcalino. A origem desses enclaves envolve magmas máficos derivados do manto litosférico enriquecido ligado ao processo de underplating, contaminados por magmas crustais durante sua ascensão e posterior colocação na câmara magmática.

A tectônica extensional e o transporte de magma por diques envolvidos na ascensão e na colocação do GrMj em níveis crustais rasos podem ser determinados a partir dos seguintes critérios:

1. diferença de idade entre o granito e suas rochas encaixantes (ca. $1 \mathrm{Ga}$ );

2. alto contraste de viscosidade, indicado pela presença de xenólitos angulosos da rocha encaixante no plúton e pelo fato de ele truncar as estruturas dúcteis de suas rochas encaixantes; 
3. influência reduzida ou nula dos esforços regionais durante a colocação do plúton sugerido pela ausência de formação no granito e de orientação do conjunto de enclaves;

4. disposição dos plútons graníticos paleoproterozoicos de Carajás coincidente com o trend geral definido pelos enxames de diques;

5. geometria tabular inferida para os batólitos da Suíte Jamon.

No modelo de construção de plútons tabulares por injeções múltiplas de magma, as variedades BMzH e BMzE do $\mathrm{GrMj}$ foram interpretadas como magmas independentes, colocados em níveis crustais rasos (ca. 1,0 $\pm 0,5 \mathrm{kbar}$ ) em um sistema de alimentação por diques. Admite-se, a partir disso, que a formação desse plúton resultou de:

1. ascensão vertical de magmas através de fraturas e acomodação ao longo dos planos da foliação regional E-W;

2. posterior mudança do fluxo vertical para um espalhamento lateral do magma, que seria responsável pela forma tabular do plúton, com subsidência do assoalho criando espaço para injeção de pulsos magmáticos sucessivos;

3. expansão in situ da câmara magmática (líquido BMzE parcialmente cristalizado) em resposta à colocação da variedade $\mathrm{BMzH}$ na porção central do corpo.

O aumento da pressão na câmara magmática resultaria no desenvolvimento de fraturas anelares acompanhadas de injeções (expulsão) do magma residente (BMzH), assim como das ocorrências de cristais de molibdenita na cúpula do GrMj durante os últimos estágios de construção do corpo. As injeções de magma máfico, responsáveis pela origem dos enclaves, deram-se durante diferentes fases de cristalização do magma granítico. Os EGp indicam que o magma máfico foi introduzido logo após o início da cristalização do granito BMzH. A ausência de feições de mingling nos EMg é indicativo de que o magma máfico foi introduzido quando o magma félsico encontrava-se em um estágio mais avançado de cristalização. Esses últimos representam partes de diques fragmentados formados por um líquido já hibridizado por mixing.

\section{AGRADECIMENTOS}

Aos pesquisadores do Grupo de Pesquisa Petrologia de Granitoides da Universidade Federal do Pará (GPPG-UFPA), o apoio nas diversas etapas deste trabalho; ao Instituto de Geociências (IG) e ao Programa de Pós-Graduação em Geologia e Geoquímica (PPGG) da UFPA, o suporte técnico; à Coordenação de Aperfeiçoamento de Pessoal de Nível Superior (CAPES), a concessão da bolsa de Mestrado ao primeiro autor; e ao projeto Conselho Nacional de Desenvolvimento Científico e Tecnológico Universal (CNPq Universal) (Proc. $n^{\circ}$ 485806/2013-4) e ao convênio Vale/Fundação Amazônia Paraense de Amparo à Pesquisa (FAPESPA) (edital 01/2010,
ICAAF: 053/2011), o apoio financeiro. Este trabalho é uma contribuição para o Instituto Nacional de Ciência e Tecnologia de Geociências da Amazônia (GEOCIAM - CNPq/MCT/ FAPESPA, Processo $n^{\circ}$ 573733/2008-2).

\section{REFERÊNCIAS}

Almeida, J. A. C., Dall'Agnol, R., Leite, A. A. S. (2013). Geochemistry and zircon geochronology of the Archean granite suites of the Rio Maria granite-greenstone terrane, Carajás Province, Brazil. Journal of South American Earth Sciences, 42, 103-126. http://dx.doi.org/10.1016/j. jsames.2012.10.008

Almeida, J. A. C., Dall'Agnol, R., Oliveira, D. C. (2006). Geologia, Petrografia e Geoquímica do Granito Anorogênico Bannach, Terreno Granito-Greenstone de Rio Maria, Pará. Revista Brasileira de Geociências, 36(2), 282-295.

Almeida, J. A. C., Dall'Agnol, R., Oliveira, M. A., Macambira, M. J. B., Pimentel, M. M., Rämö, O. T., Guimarães, F. V., Leite, A. A. S. (2011). Zircon geochronology and geochemistry of the TTG suites of the Rio Maria granite-greenstone terrane: Implications for the growth of the Archean crust of Carajás Province, Brazil. Precambrian Research, 187(1), 201-221. http://doi.org/10.1016/j.precamres.2011.03.004

Almeida, J. A. C., Guimarães, F. V., Dall'Agnol, R. (2007). Petrologia magnética do Granito Anorogênico Bannach, Terreno Granito-Greenstone de Rio Maria, Pará. Revista Brasileira de Geociências, 37(1), 17-36.

Anderson, J. L. (1983). Proterozoic anorogenic granite plutonism of North America. In: L. G. Medaris, D. M. Mickelson, C. W. Byers, W. C. Shanks (Eds.), Proterozoic Geology: Selected Papers from an International Proterozoic Symposium (v. 161, p. 133-154). Geological Society of America. https://doi.org/10.1130/MEM161-p133

Anderson, J. L., Bender, E. E. (1989). Nature and origin of Proterozoic A-type granitic magmatism in the southwestern United States of America. Lithos, 23(1-2), 19-52. http:// dx.doi.org/10.1016/0024-4937(89)90021-2

Anderson, J. L., Morrison, J. (2005). Ilmenite, magnetite, and peraluminous Mesoproterozoic anorogenic granites of Laurentia and Baltica. Lithos, 80(1-4), 45-60. https://doi. org/10.1016/j.lithos.2004.05.008

Arndt, N. T. (2013). The formation and evolution of the continental crust: Geochemical Perspectives, 2(3), 405-533. http://dx.doi.org/10.7185/geochempersp.2.3 
Barbarin, B. (1999). A review of the relationships between granitoid types, their origins and their geodynamic environments. Lithos, 46(3), 605-626. https://doi.org/10.1016/ S0024-4937(98)00085-1

Barbarin, B. (2005) Mafic magmatic enclaves and mafic rocks associated with some granitoids of the central Sierra Ne vada batholith, California: nature, origin, and relations with the hosts. Lithos, 80(1-4), 155-177. http://dx.doi. org/10.1016/j.lithos.2004.05.010

Barbarin, B., Didier, J. (1992). Genesis and evolution of mafic microgranular enclaves through various types of interaction between coexisting felsic and mafic magmas. Transactions of the Royal Society of Edinburgh Earth Sciences, 83(12), 145-153. https://doi.org/10.1017/S0263593300007835

Barbosa, A. A., Lafon, J. M., Neves, A. P., Vale, A. G. (1995). Geocronologia Rb-Sr e Pb-Pb do Granito Redenção, SE do Pará: Implicações para a evolução do magmatismo Proterozoico da região de Redenção. Boletim do Museu Paraense Emílio Goeldi, Série Ciências da Terra, 7, 147-164.

Bateman, P. C., Chappell, B. W. (1979). Crystallization, fractionation and solidification of the Tuolumne Intrusive Series, Yosemite National Park, California. Geological Society of America Bulletin, 90(5), 465-482. https://doi. org/10.1130/0016-7606(1979)90\%3C465:CFASOT\%3E2.0.CO;2

Black, L. P., Kamo, S. L., Allen, C. M., Aleinikoff, J. N., Davis, D. W., Korsch, R. J., Foudoulis, C. (2003). TEMORA 1: a new zircon standard for Phanerozoic U-Pb geochronology. Chemical Geology, 200(1-2), 155-170. https://doi.org/10.1016/S0009-2541(03)00165-7

Black, L. P., Williams, I. S., Compston, W. (1986). Four zircon ages from one rock: the history of a 3930 Ma granulite from Mount Sones, Enderby Land, Antarctica. Contributions to Mineralogy and Petrology, 94(4), 427-437. https://doi. org/10.1007/BF00376336

Bogaerts, M., Scaillet, B., Auwera, J. V. (2006). Phase Equilibria of the Lyngdal Granodiorite (Norway): Implications for the Origin of Metaluminous Ferroan Granitoids. Journal of Petrology, 47(12), 2405-2431. https://doi.org/10.1093/ petrology/eg1049

Bonin, B. (1986). Ring complex granites and anorogenic magmatism. Orleans: BRGM, 189 p.

Chappell, B. W., Bryant, C. J., Wyborn, D. (2012). Peraluminous I-type granites. Lithos, 153, 142-153. http:// dx.doi.org/10.1016/j.lithos.2012.07.008
Chappell, B. W., White, A. J. R. (1974). Two contrasting granite types. Pacific Geology, 8, 173-174.

Chappell, B. W., White, A. J. R. (2001). Two contrasting granite types: 25 years later. Australian Journal of Earth Sciences, 48(4), 489-499. https://doi.org/10.1046/j.1440-0952.2001.00882.x

Clemens, J. D., Holloway, J. R., White, A. J. R. (1986). Origin of an A-type granite: experimental constraints. American Mineralogist, 71(3), 317-324.

Collins, W. J., Beams, S. D., White, A. J., Chappell, B. W. (1982). Nature and origin of A-type granites with particular reference to Southeastern Australia. Contributions to Mineralogy and Petrology, 80(2), 189-200. https://doi. org/10.1007/BF00374895

Costa, J. B. S., Araújo, O. J. B., Santos, A., Jorge João, X. S., Macambira, M. J. B., Lafon, J. M. (1995). A Província Mineral de Carajás: Aspectos Tectono-Estruturais, Estratigráficos e Geocronológicos. Boletim do Museu Paraense Emílio Goeldi, Série Ciências da Terra, 7, 199-235.

Creaser, R. A., Price, R. C., Wormald, R. J. (1991). A-type granites revisited: assessment of a residual-source model. Geology, 19(2), 163-166. https://doi.org/10.1130/0091-7613(1991)019\%3C01 63:ATGRAO\%3E2.3.CO;2

Cruden, A. R. (2005). Emplacement and growth of plutons: implications for rates of melting and mass transfer in continental crust. In: M. Brown, T. Rushmer (Eds.), Evolution and Differentiation of the Continental Crust (p. 455-519). Cambridge: Cambridge University Press.

Dahlquist, J. A. (2002). Mafic microgranular enclaves: early segregation from metaluminous magma (Sierra de Chepes), Pampean Ranges, NW Argentina. Journal of South American Earth Sciences, 15(6), 643-655. https://doi.org/10.1016/ S0895-9811(02)00112-8

Dall'Agnol, R. (1982). Maciço Jamon: Evolução petrológica de um granito da Amazônia Oriental. I Simpósio de Geologia da Amazônia, v. 2, p. 139-161. Belém.

Dall'Agnol, R., Costi, H. T., Leite, A. A., Magalhães, M. S., Teixeira, N. P. (1999a). Rapakivi granites from Brazil and adjacent areas. Precambrian Research, 95(1-2), 9-39. http://dx.doi.org/10.1016/S0301-9268(98)00125-9

Dall'Agnol, R., Oliveira, D. C. (2007). Oxidized, magnetiteseries, rapakivi-type granites of Carajás, Brazil: Implications for classification and petrogenesis of A-type granites. Lithos, 93(3-4), 215-233. https://doi.org/10.1016/j.lithos.2006.03.065 
Dall'Agnol, R., Oliveira, M. A., Almeida, J. A. C., Althoff, F. J., Leite, A. A. S. L., Oliveira, D. C., Barros, C. E. M. (2006). Arquean and Paleoproterozoic granitoids of the Carajás Metallogenic Province, eastern Amazonian Craton. In: Symposium on Magmatism, Crustal Evolution, and Matallogenesis of the Amazonian Craton, p. 97-150. Belém: PRONEX-UFPA/SBG-NO.

Dall'Agnol, R., Ramö, O. T., Magalhães, M. S., Macambira, M. J. B. (1999b). Petrology of the anorogenic oxidised Jamon and Musa granites, Amazonian Craton: implications for the genesis of Proterozoic, A-type Granites. Lithos, 46(3), 431462. http://dx.doi.org/10.1016/S0024-4937(98)00077-2

Dall'Agnol, R., Scaillet, B., Pichavant, M. (1999c). Evolution of A-type granite magmas: an experimental study of the Lower Proterozoic Jamon Granite, eastern Amazonian craton, Brazil. Journal of Petrology, 40(11), 1673-1698. https://doi.org/10.1093/petroj/40.11.1673

Dall'Agnol, R., Teixeira, N. P., Rämö, O. T., Moura, C. A. V., Macambira, M. J. B., Oliveira, D. C. (2005). Petrogenesis of the Paleoproterozoic, rapakivi, A-type granites of the Archean Carajás Metallogenic Province, Brazil. Lithos, 80(14), 101-129. https://doi.org/10.1016/j.lithos.2004.03.058

Debon, F., Le Fort, P. (1983). A chemical-mineralogical classification of common plutonic rocks and associations. Transactions of the Royal Society of Edinburgh, Earth Sciences, 73(3), 135-149. https://doi.org/10.1017/S0263593300010117

DePaolo, D. J. (1981). Trace element and isotopic effects of combined wall-rock assimilation and fractional crystallization. Earth and Planetary Science Letters, 53(2), 189-202. http:// dx.doi.org/10.1016/0012-821X(81)90153-9

Didier, J. (1973). Granites and their enclaves. Amsterdam: Elsevier.

Donaire, T., Pascual, E., Pin, C., Duthou, J. L. (2005). Microgranular enclaves as evidence of rapid cooling in granitoid rocks: the case of the Los Pedroches granodiorite, Iberian Massif, Spain. Contributions to Mineralogy and Petrology, 149(3), 247-265. http://dx.doi.org/10.1007/s00410-005-0652-0

Dowty, E. (1980). Crystal growth and nucleation theory and the numerical simulation of igneous crystallization. In: R. B. Hargraves (Ed.), Physics of magmatic processes (p. 419551). Princeton: Princeton University Press.

Eby, G. N. (1992). Chemical subdivision of the A-type granitoids: petrogenetic and tectonic implications. Geology, 20(7), 641644. https://doi.org/10.1130/0091-7613(1992)020\%3C064 1:CSOTAT\%3E2.3.CO;2
Eby, G. N. (2006). Distinctions between A-type granites and petrogenetic pathways. In: Xavier, R. P., Dreher, A., Monteiro, L. V. S., Araújo, E. G., Wiedenbeck, M., Rhede, D. (Eds.), Symposium on Magmatism, Crustal Evolution, and Metallogenesis of the Amazonian Craton, Abstracts Volume and Field Trips Guide. Belém: PRONEX-UFPA/SBG-NO, p. 48.

Evensen, N. M., Hamilton, P. T., O'Nions, R. K. (1978). Rare-earth abundances in chondritic meteorites. Geochemical et Cosmochemical, Acta, 42(8), 1199-1212. https://doi. org/10.1016/0016-7037(78)90114-X

Feio, G. R. L., Dall'Agnol, R., Dantas, E. L., Macambira, M. J. B., Santos, J. O. S., Althoff, F. J., Soares, J. E. B. (2013). Archean granitoid magmatism in the Canaã dos Carajás area: implication for crustal evolution of the Carajás province, Amazonian craton, Brazil. Precambrian Research, 227, 157-185. https://doi.org/10.1016/j.precamres.2012.04.007

Ferreira, A. T. R. (2009). Petrografia, geoquímica e geocronologia dos diques da área de Bannach, Terreno Granito-Greenstone de Rio Maria, SE do Pará. Trabalho de Conclusão de Curso. Belém: Instituto de Geociências - UFPA.

Frost, B. R., Barnes, C. G., Collins, W. J., Arculus, R. J., Ellis, D. J., Frost, C. D. (2001). A geochemical classification for granitic rocks. Journal of Petrology, 42(11), 2033-2048. https://doi.org/10.1093/petrology/42.11.2033

Frost, C. D., Frost, B. R. (1997). Reduced rapakivi type granites: the tholeiitic connection. Geology, 25(7), 647-650. https://doi.org/10.1130/0091-7613(1997)025\%3C0647:RR TGTT\%3E2.3.CO;2

Frost, C. D., Frost, B. R. (2013). Proterozoic ferro and feldspathic magmatism. Precambrian Research, 228, 151163. https://doi.org/10.1016/j.precamres.2013.01.016

Frost, C. D., Frost, B. R., Chamberlain, K. R., Edwards, B. (1999). Petrogenesis of the 1.43 Ga Sherman batholith, SE Wyoming, USA: a reduced, rapakivi-type anorogenic granite. Journal of Petrology, 40(12), 1771-1802. https:// doi.org/10.1093/petroj/40.12.1771

Gabriel, E. O. (2012). Geologia, geoquimica e petrologia magnética dos granitoides arqueanos da porção Nordeste de Água Azul do Norte (PA) - Província Carajás. Dissertação (Mestrado). Belém: Programa de Pós-Graduação em Geologia e Geoquímica, Instituto de Geociências - UFPA.

Gastal, M. C. P. (1987). Petrologia do Maciço Granítico Musa. Sudeste do Pará. Dissertação (Mestrado). Belém: Centro de Geociências - UFPA. 
Gastal, M. C. P. (1988). Magmatismo ácido-intermediário do Proterozóico Médio da região de Rio Maria, SE do Pará: discussão quanto à tipologia. $X X X V$ Congresso Brasileiro de Geologia, Anais, 3, 1147-1163. Belém: SBG.

Gebauer, D., Grünenfelder, M. (1979). U-Pb-Th dating of minerals. In: E. Jäger, J. C. Hunziker (Eds.), Lectures in Isotope Geology (105-131). Berlim, Springer.

Guimarães, F. V., Dall'Agnol, R., Oliveira, D. C., Silva, A. C., Teixeira, M. F. B., Santos, P. A. (2012). Geologia preliminar da porção Leste do Subdomínio de Transição da Província Carajás - PA. $46^{\circ}$ Congresso Brasileiro de Geologia. Santos: Sociedade Brasileira de Geologia.

Hibbard, M. J. (1995). Petrografy to Petrogenesis. New Jersey: Prentice Hall.

Huhn, S. R. B., Santos, A. B. S., Amaral, A. F., Ledsham, E. J., Gouveia, J. L., Martins, L. B. P., Montalvão, R. M. G., Costa, V. G. (1988). O terreno granito greenstone da região de Rio Maria-sul do Pará. XXXV Congresso Brasileiro de Geologia, 3, 1438-1453. Belém: SBG.

Huppert, H. E., Sparks, R. S. (1988). The generation of granitic magmas by intrusion of basalt into continental crust. Journal of Petrology, 29(3), 599-624. https://doi. org/10.1093/petrology/29.3.599

Ishihara, S. (1977). The magnetite-series and ilmenite-series granitic rocks. Mining Geology, 27(145), 293-305. https:// doi.org/10.11456/shigenchishitsu1951.27.293

King, P. L., Chappell, B. W., Allen, C. M., White, A. J. R. (2001). Are A-type granites the hightemperature felsic granites? Evidence from fractionated granites of the Wangrah Suite. Australian Journal of Earth Sciences, 48(4), 501-514. https://doi. org/10.1046/j.1440-0952.2001.00881.x

King, P. L., White, A. J. R., Chappell, B. W., Allen, C. M. (1997). Characterization and origin of aluminous A-type granites from the Lachlan Fold Belt, southeastern Australia. Journal of Petrology, 38(3), 371-391. https://doi.org/10.1093/ petroj/38.3.371

Kinny, P. D., Williams, I. S., Froude, D. O., Ireland, T. R., Compston, W. (1988). Early Archean zircon ages from orthogneiss and anorthosites at Mount Narryer, Western Australia. Precambrian Research, 38(4), 325-341. https:// doi.org/10.1016/0301-9268(88)90031-9
Lamarão, C. N., Pinho, S. C. C., Paiva Júnior, A. L., Galarza, M. A. (2012). Mineralogy and geochemistry of the Paleoproterozoic, tin-mineralized Bom Jardim Granite of the Velho Guilherme Suite, eastern Amazonian Craton. Journal of South American Earth Science, 38, 159-173. http://dx.doi.org/10.1016/j.jsames.2012.05.004

Leite, A. A. S. (2001). Geoquímica, petrogênese e evolução estrutural dos granitoides arqueanos da região de Xinguara, SE do Cráton Amazônico. Tese (Doutorado). Belém: Instituto de Geociências - UFPA.

Le Maitre, R. W. (2002). A classification of igneous rocks and glossary of terms. London: Cambridge, $193 \mathrm{p}$.

Lima, P. H. A. (2011). Geologia, Petrografia e Geocronologia do Granito São João, Província Carajás, SSE do Pará. Trabalho de Conclusão de Curso. Belém: Instituto de Geociências - UFPA.

Loiselle, M. C., Wones, D. R. (1979). Characteristics and origin of anorogenic granites. Abstracts with programs, Geological Society of America, 11, 468.

Ludwig, K. R. (2003). Isoplot/Ex, a geochronological toolkit for Microsoft Excel, version 3.00. Berkeley: Berkeley Geochronology Center, n. 1, 43 p.

Ludwig, K. R. (2009). Isoplot v. 4 for Excel 2007. Berkeley: Berkeley Geochronology Center, 71 p.

Macambira, M. J. B. (1992). Chronologie U/Pb, Rb/Sr, K/ Ar et croissance de la croûte continentale dans L'Amazonie du sud-est; exemple de la région de Rio Maria, Province de Carajas, Brésil. Tese (Doutorado). Montpellier: Université Montpellier II-France.

Machado, N., Lindenmayer, Z., Krogh, T. H., Lindenmayer, D. (1991). U-Pb geochronology of Archaean magmatism and basement reactivation in the Carajás area, Amazon shield, Brazil. Precambrian Research, 49(3-4), 329-354. https:// doi.org/10.1016/0301-9268(91)90040-H

Mahon, K. I., Harrison, T. M., Drew, D. A. (1988). Ascent of a granitoid diapir in a temperature varying medium. Journal of Geophysics, 93(B2), 1174-1188. https://doi.org/10.1029/ JB093iB02p01174

Marsh, B. D. (1982). On the mechanics of igneous diapirism, stoping, and zone melting. American Journal of Science, 282(6), 808-855. https://doi.org/10.2475/ ajs.282.6.808 
McDonough, W. F., Sun, S. S. (1995). Composition of the Earth. Chemical Geology, 120(3-4), 223-253. https://doi. org/10.1016/0009-2541(94)00140-4

Nardi, L. V. S., Bitencourt, M. F. (2009). A-type granitic rocks in post-collisional settings in southernmost Brazil: their classification and relationship with tectonics and magmatic series. The Canadian Mineralogy, 47(6), 1493-1504. https:// doi.org/10.3749/canmin.47.6.1493

Oliveira, D. C. (2006). Modelos de Evolução e Colocação dos Granitos Paleoproterozoicos da Suite Jamon, SE do Cráton Amazônico. Tese (Doutorado). Belém: Instituto de Geociências - UFPA.

Oliveira, D. C., Dall'Agnol, R., Barros, C. E. M., Oliveira, M. A. (2009). Geology, geochemistry and magmatic evolution of the Paleoproterozoic, anorogenic oxidized A-type Redenção granite of the Jamon Suite, eastern Amazon Craton, Brazil. Canadian Mineralogist, 47(6), 1323-1349. http://dx.doi. org/10.3749/canmin. 47.6 .000

Oliveira, D. C., Dall'Agnol R., Barros, C. E. M., Vale, A. G. (2005). Geologia e Petrografia do Granito Paleoproterozóico Redenção, SE do Cráton Amazônico. Boletim do Museu Paraense Emílio Goeldi, Série Ciências Naturais, 1(2), 139-156.

Oliveira, D. C., Dall'agnol, R., Silva, J. B. C., Almeida, J. A. C. (2008). Gravimetric, radiometric, and magnetic susceptibility study of the Paleoproterozoic Redenção and Bannach plutons: implications for architecture and zoning of A-type granites. Journal of South American Earth Sciences, 25(1), 100-115. http://dx.doi.org/10.1016/j.jsames.2007.10.003

Oliveira, D. C., Neves, S. P., Trindade, R. I. F., Dall'Agnol, R., Mariano, G., Correia, P. B. (2010). Magnetic anisotropy of the Redenção granite, eastern Amazonian craton (Brazil): Implications for the emplacement of A-type. Tectonophysics, 493(1-2), 27-41. http://dx.doi.org/10.1016/j.tecto.2010.07.018

Paiva Júnior, A. L. (2009). Geologia, petrografia, geocronologia e geoquímica do Granito anorogênico Seringa, Província Mineral de Carajás, SSE do Pará. Dissertação (Mestrado). Belém: Instituto de geociências - UFPA.

Paradella, W. R., Santos, A. R., Dall'Agnol, R., Pietsch, R. W., Sant'Anna, M. V. (1998). A Geological investigation based on airborne (Sarex) and spaceborne (Radarsat-1) SAR integrated products in the Central Serra dos Carajás granite area, Brazil. Canadian Journal of Remote Sensing, 24(4), 376-392. http://doi.org/10.1080/07038992.1998.10874702
Paterson, S. R., Pignotta, G. S., Vernon, R. H. (2004). The significance of microgranitoid enclave shapes and orientations. Journal of Structural Geology, 26(8), 1465-1481. https:// doi.org/10.1016/j.jsg.2003.08.013

Patiño Douce, A. E. (1997). Generation of metaluminous A-type granites by low-pressure melting of calcalkaline granitoids. Geology, 25(8), 743-746. https://doi. org/10.1130/0091-7613(1997)025\%3C0743:GOMATG\% 3E2.3.CO;2

Patiño Douce, A. E. (1999). What do experiments tell us about the relative contributions of crust and mantle to the origin of granitic magmas? In: A. Castro, C. Fernandez, J. L. Vigneresse (Eds.), Understanding Granites: New and Classical Techniques, v. 168, p. 55-75. Londres: Geological Society, Special Publication.

Pearce, J. A., Harris, N. B. W., Tindle, A. G. (1984). Trace element discrimination diagrams for the tectonic interpretation of granitic rocks. Journal of Petrology, 25(4), 956-983. https://doi.org/10.1093/petrology/25.4.956

Perugini, D., Poli, G. (2012). The mixing of magmas in plutonic and volcanic environments: Analogies and differences. Lithos, 153, 261-277. https://doi.org/10.1016/j. lithos.2012.02.002

Petford, N. (1996). Dikes or diapirs? Transactions of the Royal Society of Edinburgh: Earth Sciences, 87(1-2), 105114. https://doi.org/10.1017/S0263593300006520

Petford, N., Cruden, A. R., McCaffrey, K. J. W., Vigneresse, J. L. (2000). Granite magma formation, transport and emplacement in the Earth's crust. Nature, 408(6813), 669673. https://doi.org/10.1038/35047000

Phillips, E. R. (1974). Myrmekite - One hundred years later. Lithos, 7(3), 181-194. https://doi. org/10.1016/0024-4937(74)90029-2

Pitcher, W. S. (1982). Granite type and tectonic environment. In: K. J. Hsu (Ed.), Mountain Building Processes, p. 19-40. Londres: Academic Press.

Pitcher, W. S. (1993). The Nature and Origin of Granite. Londres: Blackie Academic and Professional, 312 p.

Pitcher, W. S., Berger, A. R. (1972). The controls of contact metamorphism. In: W. S. Pitcher, A. R. Beger (Eds.), The geology of Donegal: a study of granite emplacement and unroofing, p. 302-327. Nova York: John Wiley \& Sons. 
Rajesh, H. M. (2000). Characterization and origin of a compositionally zoned aluminous A-type granite from South India. Geological Magazine, 137(3), 291-318.

Rämö, O. T., Dall'Agnol, R., Macambira, M. J. B., Leite, A. A. S., Oliveira, D. C. (2002). 1.88 Ga oxidized A-type granites of the Rio Maria region, eastern Amazonian craton, Brazil: Positively anorogenic! Journal of Geology, 110(5), 603-610. https://doi.org/10.1086/341761

Rämö, O. T., Haapala, I. (1995). One hundred years of rapakivi granite. Mineralogy and Petrology, 52(3-4), 129185. http://dx.doi.org/10.1007/BF01163243

Rivalenti, G., Mazzuchelli, M., Girardi, V. A. V., Cavazzini, G., Finatti, C., Barbieri, M. A., Teixeira, W. (1998). Petrogenesis of the Paleoproterozoic basaltic- andesiterhyolite dyke association in the Carajás region, Amazonian craton. Lithos, 43(4), 235-265. http://dx.doi.org/10.1016/ S0024-4937(98)00015-2

Rocha Júnior, G. L. D. (2004). Caracterização petrográfica do Granito Paleoproterozóico Marajoara, Terreno Granito-Greenstone de Rio Maria, SE do estado do Pará. Trabalho de Conclusão de Curso. Belém: Instituto de Geociências - UFPA.

Rodrigues, E. S., Lafon, J. M., Scheller, T. (1992). Geocronologia $\mathrm{Pb}-\mathrm{Pb}$ da Província Mineral de Carajás: primeiros resultados. XXXVII Congresso Brasileiro de Geologia, Boletim de Resumos Expandidos, 2, 183-184. São Paulo: SBG.

Santos, J. O. S. (2003). Geotectônica do Escudo das Guianas e Brasil-Central. In: L. A. Bizzi, C. Chobbenhaus, J. H. Gonçalves, F. J. Baars, I. M. Delgado, M. B. Abram, R. Leão Neto, G. M. M. de Matos, J. O. S. Santos (Eds.). Geologia, tectônica e recursos minerais do Brasil: texto, mapas e SIG, p. 169-226. Brasília: Serviço Geológico do Brasil.

Sato, K., Basei, M. A. S., Siga Júnior, O., Sproesser, W. M., Passarelli, C. R. (2008). Novas técnicas aplicadas ao método U-Pb no CPGeo - IGc/USP: avanços na digestão química, espectrometria de massa (TIMS) e exemplos de aplicação integrada com SHRIMP. Geologia USP. Série Cientifica, 8(2), 76-99. https://doi.org/10.5327/Z1519-874X2008000200006

Serviço Geológico do Brasil (CPRM) (2000). Folha Caracarai: Folhas NA.20-Z-B e NA.20-Z-D (integrais), NA.20-Z-A, NA.21-Y-A, NA.20-Z-C e NA.21-Y-C (parciais). Escala 1:500.000. Estado de Roraima. Brasília, DF. 1 CD-ROM. (Programa Levantamentos Geológicos Básicos do Brasil - PLGB).
Siivola, J., Schmid, R. (2007). List of mineral abbreviations: recommendations by the IUGS Subcommission on the Systematics of Metamorphic Rocks. Web version 01.02.07. Disponível em: <http://www.bgs.ac.uk/scmr/docs/papers/ paper_12.pdf $>$. Acesso em: 22 abr. 2017.

Silva, F. F., Oliveira, D. C., Antonio, P. Y. J., D’Agrella Filho, M. S., Lamarão, C. N. (2016). Bimodal magmatism of the Tucuma area, Carajás as province: U-Pb geochronology, classification and processes. Journal of South American Earth Sciences, 72, 95-114. http://dx.doi.org/10.1016/j. jsames.2016.07.016

Silva Júnior, R. O, Dall'Agnol, R., Oliveira, E. P. (1999). Geologia, petrografia e geoquímica dos diques proterozoicos da região de Rio Maria, sudeste do Pará. Geochimica Brasiliensis, 13(2), 163-181. https://doi.org/10.21715/gb.v13i2.161

Skjerlie, K. P., Johnston, A. D. (1993). Fluid-absent melting behavior of F-rich tonalitic gneiss at mid-crustal pressures: implications for the generation of anorogenic granites. Journal of Petrology, 34(4), 785-815. https://doi.org/10.1093/ petrology/34.4.785

Smith, J. V. (1974). Feldspar Minerals. Nova York: SpringerVerlag, $690 \mathrm{p}$.

Sommerauer, J. (1974). Trace element distribution patterns and the mineralogical stability of zircon - an application for combined electron microprobe techniques. Electron Microscopy Society of South Africa, 4, 71-72.

Souza, S. Z., Dall'agnol, R., Althoff, F. J., Leite, A. A. S., Barros, C. E. M. (1996). Carajás Mineral Province: geological, geochronological and tectonic constrasts on the Archean evolution of the Rio Maria Granite-Greenstone Terrain and the Carajás block. Symposium on Archean Terranes of South America Platform, 1, 31-32. Brasília: SBG.

Souza, Z. S., Medeiros, H., Althoff, F. J., Dall'agnol, R. (1990). Geologia do terreno granito-greenstone Arqueano da região de Rio Maria, sudeste do Pará. XXXVI Congresso Brasileiro de Geologia, 6, 2913-2928. Natal: SBG.

Steiger, R. H., Wasserburg, G. J. (1966). Systematics in the $\mathrm{Pb}^{208}-\mathrm{Th}^{232}, \mathrm{~Pb}^{207}-\mathrm{U}^{235}$, and $\mathrm{Pb}^{206}-\mathrm{U}^{238}$ systems. Journal of Geophysical Research, 71(24), 6065-6090. https://doi. org/10.1029/JZ071i024p06065

Stephens, W. E., Halliday, A. N. (1979). Compositional variation in the Galaway pluton. In: Atherton, M. P., Tarney, J. (Eds.). Origin of Granite Batholiths: Geochemical Evidence. Orpington: Shiva, p. 9-17. 
Stern, R. A. (1998). High resolution SIMS determination of radiogenic trace isotope ratios in minerals. In: L. J. Cabri, D. J. Vaughan (Eds.), Modern approaches to ore and environmental mineralogy. Mineralogical Association of Canada. Short Course Series, 27, 241-268.

Streckeisen, A. (1976). To each plutonic rock its proper name. Earth Science Reviews, 12(1), 1-33. https://doi. org/10.1016/0012-8252(76)90052-0

Sylvester, P. J. (1989). Post-collisional alkaline granites. Journal of Geology, 97(3), 261-280.

Tassinari, C. C. G., Macambira, M. (2004). A evolução tectônica do Cráton Amazônico. In: V. Mantesso-Neto, A. Bartorelli, C. D. R. Carneiro, B. B. Brito Neves (Eds.), Geologia do Continente Sul Americano: Evolução da obra de Fernando Flávio Marques Almeida, p. 471-486. São Paulo.

Teixeira, N. P. (1999). Contribuição ao estudo das rochas granitoides e mineralizações associadas da Suite Intrusiva Velho Guilherme, Província Estanifera do Sul do Pará. Tese (Doutorado). São Paulo: Instituto de Geociências - USP. https://doi.org/10.11606/T.44.1999. tde-22122015-110743

Tilton, G. R. (1960). Volume diffusion as a mechanism for discordant lead ages. Journal of Geophysical Research, 65(9), 2933-2945. https://doi.org/10.1029/JZ065i009p02933

Vance, J. A. (1965). Zoning in igneous plagioclase: patchy zoning. The Journal of Geology, 73(4), 636-651. http:// dx.doi.org/10.1086/627099

Vasquez, M. L., Rosa-Costa, L. R., Silva, C. G., Ricci, P. F., Barbosa, J. O., Klein, E. L., Lopes, E. S., Macambira, E. B., Chaves, C. L., Carvalho, J. M., Oliveira, J. G., Anjos, G. C., Silva, H. R. (2008). In: M. L. Vasquez, L. T. RosaCosta (Orgs.), Geologia e recursos minerais do Estado do Pará: Sistema de Informações Geográficas - SIG: texto explicativo dos mapas Geológico e Tectônico e de Recursos Minerais do Estado do Pará. Escala 1:1.000.000. Belém: CPRM.
Waight, T. E., Wiebe, R. A., Krogstad, E. J. (2007). Isotopic evidence for multiple contributions to felsic magma chambers: Gouldsboro granite, coastal Maine. Lithos, 93(3-4), 234-247. https://doi.org/10.1016/j.lithos.2006.03.066

Wasserburg, G. J. (1963). Diffusion processes in lead-uranium systems. Journal of Geophysical Research, 68(16), 48234846. https://doi.org/10.1029/JZ068i016p04823

Wetherill, G. W. (1956a). An interpretation of the Rhodesia and Witwatersrand age patterns. Geochimica et Cosmochimica Acta, 9(5-6), 290-292. https://doi. org/10.1016/0016-7037(56)90029-1

Wetherill, G. W. (1956b). Discordant uranium-lead ages. Transactions American Geophysical Union, 37(3), 320-326. https://doi.org/10.1029/TR037i003p00320

Whalen, J. B., Currie, K. L., Chappell, B. W. (1987). A-types granites: geochemical characteristics, discrimination and petrogenesis. Contributions of Mineralogy and Petrology, 95(4), 407-419. https://doi.org/10.1007/BF00402202

White, A. J. R., Chappell, B. W., Wyborn, D. (1999). Application of the restite model to the Deddick Granodiorite and its enclaves - a re-interpretation of the observations and data of Maas et al. (1997). Journal of Petrology, 40(3), 413421. https://doi.org/10.1093/petroj/40.3.413

Williams, I. S. (1998). U-Th-Pb geochronology by ion microprobe. In: M. A. McKibben, W. C. W. I. Shanks Ridley, (Eds.). Applications of microanalytical techniques to understanding mineralizing processes, 7, 1-35. Society of Economic Geologists. https://doi.org/10.5382/Rev.07

Wu, F. Y., Jahn, B. M., Wilde, S. A., Lo, C. H., Yui, T. F., Lin, Q., Ge, W. C., Sun, D. Y. (2003a). Highly fractionated I-type granites in NE China (I): geochronology and petrogenesis. Lithos, 66(34), 241-273. https://doi.org/10.1016/S0024-4937(02)00222-0

Yang, J. H., Wu, F. Y., Chung, S. L., Wilde, S. A., Chu, M. F. (2006). A hybrid origin for the Qianshan A-type granite, northeast China: geochemical and Sr-Nd-Hf isotopic evidence. Lithos, 89(1-2), 89-106. https://doi.org/10.1016/j.lithos.2005.10.002 